Portland State University

PDXScholar

Spring 6-8-2017

\title{
Settler Visions of Health: Health Care Provision in the Central African Federation, 1953-1963
}

Catherine Janet Valentine

Portland State University

Follow this and additional works at: https://pdxscholar.library.pdx.edu/open_access_etds

Part of the African History Commons, and the African Studies Commons Let us know how access to this document benefits you.

\section{Recommended Citation}

Valentine, Catherine Janet, "Settler Visions of Health: Health Care Provision in the Central African Federation, 1953-1963" (2017). Dissertations and Theses. Paper 4020.

https://doi.org/10.15760/etd.5904

This Thesis is brought to you for free and open access. It has been accepted for inclusion in Dissertations and Theses by an authorized administrator of PDXScholar. Please contact us if we can make this document more accessible: pdxscholar@pdx.edu. 
Settler Visions of Health:

Health Care Provision in the Central African Federation, 1953-1963

by

Catherine Valentine

A thesis submitted in partial fulfillment of the requirements for the degree of

Master of Arts

in

History

Thesis Committee:

Jennifer Tappan, Chair

Richard Beyler

Laura Robson

Melissa Graboyes

Portland State University

2017 
(C) 2017 Catherine Valentine 


\begin{abstract}
$\underline{\text { Abstract }}$
This thesis examines healthcare provision in the Central African Federation, the late colonial union between the British colonies of Southern Rhodesia, Northern Rhodesia, and Nyasaland (the later independent nations of Zimbabwe, Zambia, and Malawi respectively). Unusually in federal formations, healthcare delivery in the Federation of Rhodesia and Nyasaland became a federal function. "Settler Visions of Health" seeks to explain how the white settler elite reconciled the language of development and multiracial partnership with the underlying values of a settler society. Throughout its short existence, the Federal Health Service maintained a celebratory narrative of success designed to legitimize and justify both the decision to federate health and the Federation's existence. The takeover of health allowed the federal government to project an image of the Federation as a rapidly developing, progressive nation that had brought significant benefits to the standard of living of African people. The reality was more checkered. The Federal Health Service struggled to live up to its promise of benevolent biopower. It largely perpetuated a colonial legacy that neglected to establish solid foundations of health consisting of sufficient infrastructure, adequate training, and equitable healthcare policies. I argue that the decision to federate health is best understood within a context of settler nation building and that paying attention to the rhetoric and realities of healthcare provision in the Federation illustrates how progressive ideas about access to healthcare and medical careers for African people could serve to maintain a settler colonial order. In addition to maintaining earlier colonial inequities of healthcare provision, federal healthcare policies and practices tended to marginalize
\end{abstract}


health delivery in the northern territories contributing to the fragile health systems that Zambia and Malawi inherited when they attained independence. 


\section{$\underline{\text { Acknowledgements }}$}

This thesis is the culmination of an academic journey that began some years ago as an undergraduate at Portland State University. As such I am indebted to the support and encouragement I have received from the many faculty members of the history department that I have been privileged to work with. I entered the Master of History program at Portland State because I wanted the opportunity to carry out a major research project. It has certainly lived up to expectations. Writing this thesis has been challenging but ultimately deeply rewarding.

I am not sure that I can ever adequately express my thanks to my advisor, Jennifer Tappan for all that she has done. Her thoughtful and compassionate teaching of the African past has been inspirational and was a major factor in my decision to go onto graduate school. As my mentor for this project, Jennifer has been a constant source of inspiration. She had an uncanny knack for picking me up when self-doubts threatened the entire endeavor while holding me accountable to get the thesis completed! Thank you, Jenn.

I would also like to thank the other members on my committee. I was privileged to have a second Africanist as my outside reader. Melissa Graboyes travelled to Portland from Eugene for my defense and my thesis is that much stronger for her insightful criticism. Laura Robson and Richard Beyler similarly helped me hone my thinking about my project. 
An unforeseen benefit of this work has been the opportunity to interact with scholars from around the world. In Africa, Clement Masakure and Walima Kalusa were quick to respond to my questions about various aspects of my research. British scholar Colin Baker deserves a special mention. An ex-colonial administrative officer and historian of Malawi, Colin provided me with a great deal of information and pointed me to pertinent archival sources for my project. Pamela Shurmer-Smith introduced me to a number of ex-colonials who gave me information about working in the Central African Federation. The staff of the various archives and libraries in London, Edinburgh, and Oxford patiently responded to my requests for research material and graciously suggested other sources.

I owe a debt of gratitude to many outside academia too. My friends in the Portland tennis world, some of whom, no doubt, heard more about my project than they wished to, supported and encouraged me. Liz Lamade and Bob Calo generously opened their home to me in London. Heartfelt thanks also go to my family in Australia and South Africa. My adult children, Andy and Claire have always been there for me.

Finally, I am profoundly grateful for the emotional and financial support that I have received from my husband and best friend, Ian. I have lost count of the number of delicious and sustaining meals he has cooked for me while I have been buried in books and paper. Thank you, Ian, for everything. 


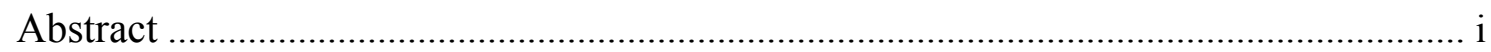

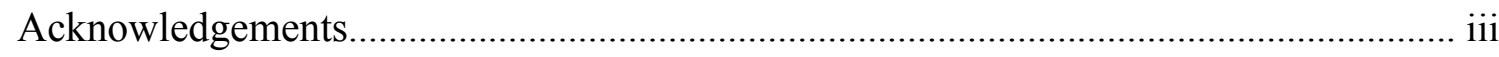

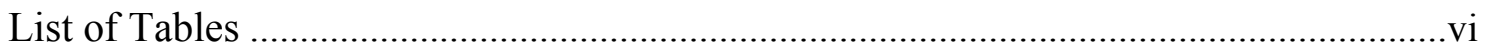

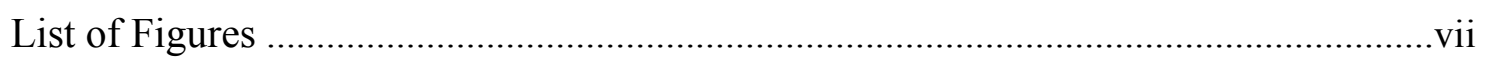

Introduction....................................................................

\section{Chapter One}

Shaky Foundations of Healthcare in Central Africa................................. 31

Chapter Two

Federating Health........................................................57

Chapter Three

Creating a "Great Health Service," 1954-1958..................................86

Chapter Four

The Struggle to Maintain a Colonial Medical Order, 1959-1963...................117

\section{Epilogue}

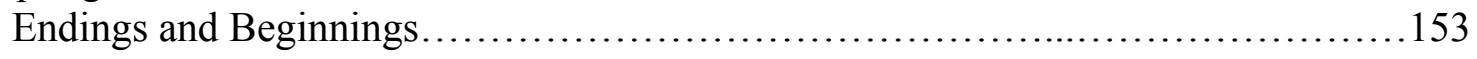

Bibliography.......................................................... 168 


\section{List of Tables}

Table 1 Staffing: European Government Hospitals, Central African Federation, 1959.

Table 2 Staffing: African Government Hospitals, Central African Federation, 1959. 


\section{List of Figures}

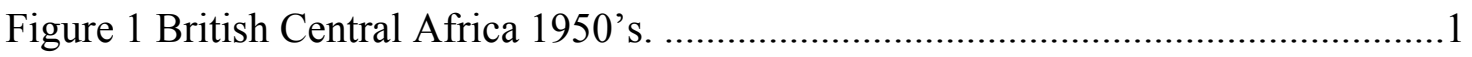


BRITISH CENTRAL AFRICA 1950's

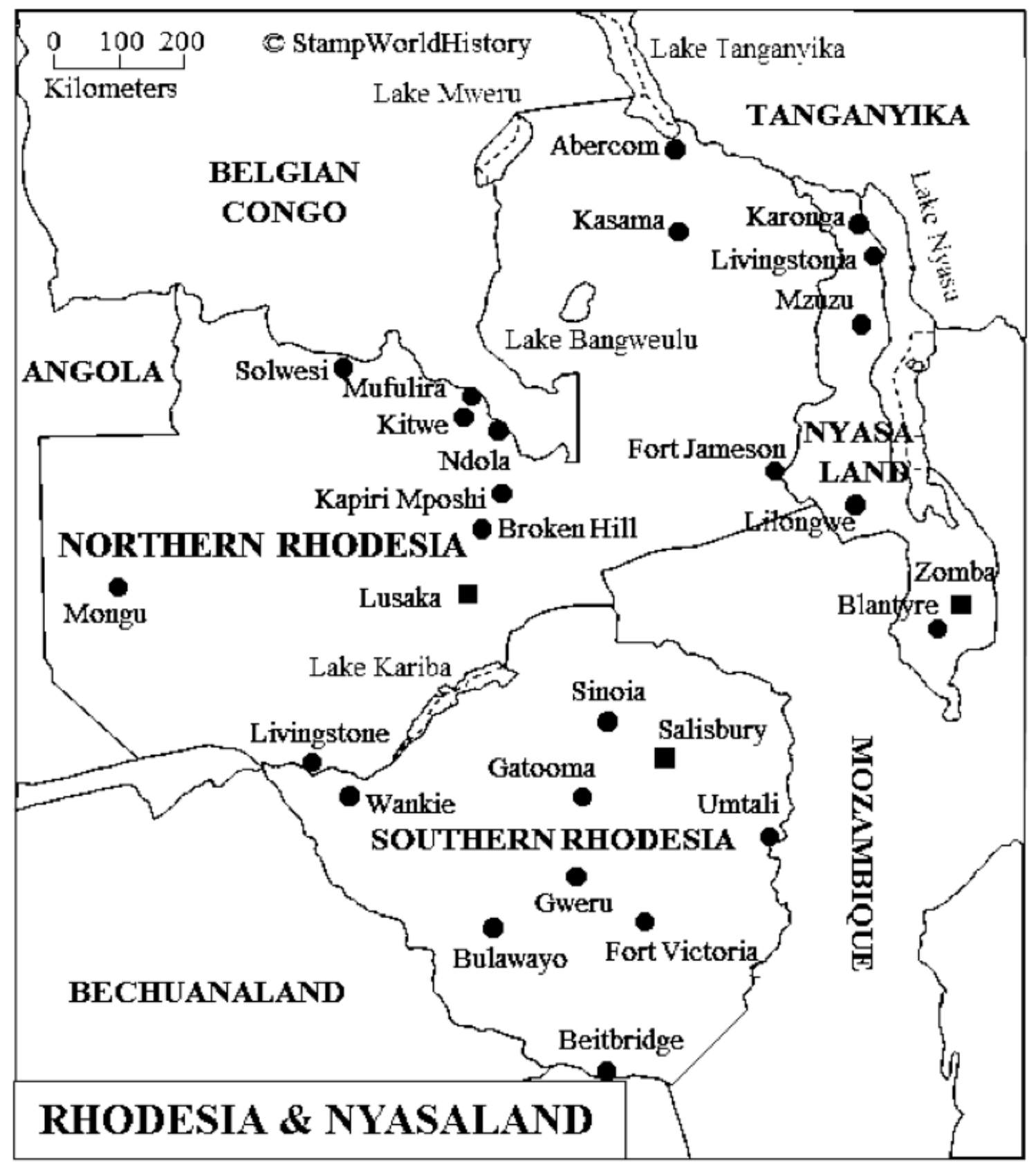

Source: www.stampworldhistory.com. 


\section{$\underline{\text { Introduction }}$}

"Although the forward vision and bright ideals of the Federal Ministry withered at the end of [Federation], ... it can be justly claimed that the Federal Government in its nearly 10 years of life gave a great impetus and drive to the development of health and medical service of the Federation... The Federal Ministry of Health made a major contribution to the improvement in health and happiness of all the people of the Federation."

This thesis is the story of how a postwar vision of health manifested in a late colonial developmentalist setting. The Central African Federation, created in 1953, was the political union between the British colonies of Southern and Northern Rhodesia and Nyasaland. ${ }^{2}$ The colonies were very different in character. Southern Rhodesia was a settler society and had enjoyed virtual political autonomy since 1923 . $^{3}$ Northern Rhodesia and Nyasaland were administered by the British Colonial Office through the institution of Indirect Rule, a system of Native Authority designed to organize labor, collect taxes, and enforce law. Their economies, too, were different. Northern Rhodesia's was dominated by copper mining, Nyasaland was predominantly agricultural, and Southern Rhodesia's was mixed.

\footnotetext{
${ }^{1}$ Federation of Rhodesia and Nyasaland, Annual Reports on Public Health, British Online Archives (BOA), 1963, 2-3.

2 These are the present African nations of Zimbabwe, Zambia, and Malawi respectively. The Central African Federation was also widely known as the Federation of Rhodesia and Nyasaland but also as British Central Africa or Central Africa or simply the Federation. I use all terms interchangeably. For general histories of the colonies see Alois S. Mlambo, A History of Zimbabwe (Cambridge: Cambridge University Press, 2014); John McCracken, A History of Malawi (Rochester, NY: James Currey, 2012); Andrew Roberts, A History of Zambia (New York: Africana Pub., 1976); For a more recent political history of Zambia see B. J. Phiri, A Political History of Zambia : From Colonial Rule to the Third Republic, 1890-2001 (Trenton, NJ: Africa World Press, 2006).

${ }^{3}$ Southern Rhodesia came under the remit of the Commonwealth Relations Office.
} 
A closer association between the colonies of Southern Rhodesia, Northern Rhodesia, and Nyasaland gained currency in the aftermath of the Second World War. ${ }^{4}$ The rapid development of the Copperbelt made Northern Rhodesia attractive to a Southern Rhodesia desirous of capital for development of its manufacturing infrastructure. At the same time, a vibrant post war economy and increasing numbers of settlers fueled settler nationalism within Northern Rhodesia. Settler interest coalesced with British fears of Afrikaner expansionism in the wake of the election of the Nationalist party in South Africa in 1948. ${ }^{5}$ Thus, from around 1950, the idea of a political alliance between Northern and Southern Rhodesia had bilateral support. Nyasaland was included almost as an afterthought. The British government wished to divest itself of the financial obligations of developing the colony while the Southern Rhodesia government saw it as the price to be paid for the bigger prize of harnessing the economic engine of Northern Rhodesia.

A major premise of federation was that Africans, particularly those of the emerging middle class, would realize substantial material and political benefits in the

${ }^{4}$ For history of the process by which Federation came into being see: J.R.T. Wood, The Welensky Papers: A History of the Federation and Nyasaland, Durban, SA: Graham Publishing, 1983. Also see Philip Murphy, "Introduction," in British Documents on the End of Empire: Central Africa, Part I: Closer Association 1945-1958, ed. Philip Murphy (London: The Stationary Office, 2005), xxvii-cxvi.

${ }^{5}$ For the geopolitical considerations of Federation see: Ronald Hyam, "The Geopolitical Origins of the Central African Federation: Britain, Rhodesia and South Africa, 19481953," The Historical Journal 30, 1 (1987): 145-72. For a different perspective highlighting the importance of settler nationalism in Central Africa see: Philip Murphy, "'Government By Blackmail': The Origins of the Central African Federation Reconsidered in The British Empire in the 1950s: Retreat or Revival, ed. Martin Lynn, 53-76. London: Palgrave Macmillan, 2006. 
form of a "racial partnership" with the white settlers. Racial partnership was a loose term that could be molded to match the aspirations of the elite African and the white settler. To elite and upwardly mobile Africans, "partnership" appeared to promise the possibility of a multiracial society based on "equal rights for all civilized men." The appeal of racial partnership was strong enough, at least in Southern Rhodesia, to convince many African elites that amalgamation into the white settler society was possible. ${ }^{7}$ For the white settler ruling class, racial partnership was a means of dampening African nationalism by throwing a few crumbs of political participation to the African elite. ${ }^{8}$

In March of 1954, the newly created federal government passed legislation making the provision of health services a federal function. For the next decade, the responsibility for health care provision for nearly six million African people rested in the hands of a white settler elite. The Federal Health Service brought together three disparate colonial health systems. In Southern Rhodesia, a large European minority fostered a vibrant private practice sector and African healthcare was predicated on preserving European health. In Northern Rhodesia, reliance on revenue from the copper industry produced a political economy of health based on ensuring a plentiful supply of black labor. In Nyasaland, as well as in Northern Rhodesia, the emphasis was on providing health care commensurate with the economic standing of the colony. In effect this meant that health care was rudimentary, especially outside urban areas. Most rural Africans, if they had access to government healthcare at all, received it from basic dispensaries.

6 "Equal rights for all civilized men" was borrowed from Cecil Rhodes and became the rallying cry of the African middle class in the 1950s. Michael West, The Rise of an African Middle Class (Bloomington, IN, Indiana University Press, 2002), 193. 7 Ibid.

${ }^{8}$ Ibid. 
Religious missions provided the bulk of rural healthcare.

The aims and objectives of the Federal Health Service included the promise to improve rural and urban health infrastructure, invest in the provision of locally trained medical personnel, and provide a health system that served all the people of the Federation. In addition, the service promised to privilege research into endemic tropical diseases such as bilharziasis and malaria while undertaking to provide facilities to allow "patients of any race... treatment for practically every condition.." This was a bold assertion given the historically low level of health care infrastructure in colonial Central Africa. Furthermore, in keeping with the colonial past, healthcare was to be provided free of charge to all Africans, all government employees, and those Europeans who could not afford to pay. ${ }^{10}$

\section{Visions of Health and Development}

The Central African Federation was a late colonial developmentalist state, but one in which development policies were an integral part of settler nation-building. ${ }^{11}$ There are two schools of thought as to the role of welfare and development in colonial state

9 Roy Welensky, "In the Federal Assembly: Extract on Health from "The Break Up" Effects and Consequences on the Two Rhodesias, Central African Journal of Medicine (CAJM), 9 (1963), 296.

${ }^{10}$ Luke Messac argues that free healthcare for Africans emerged as a benevolent recompense for colonial taxation, to quell resentment against colonial rule, but also because of a desire to suppress African healing systems in order to foster a de-politicized ontology of healing. Of course the irony here is that biomedicine is itself inherently political in nature. Luke Messac, "Moral hazards and Moral Economies: The Combustible Politics of Healthcare User Fees in Malawian History," South African Historical Journal, 66, 2 (2014), 376-380.

${ }^{11}$ See for example, Julia Tischler, Light and Power for a Multiracial Nation: The Kariba Dam Scheme in the Central African Federation, (Houndmills, Basingstoke, Hampshire: Palgrave Macmillan, 2013). 
building. Crawford Young argues that welfare and development was a belated legitimation discourse, a view that Nancy Hunt follows when she considers the role of medical services in the Belgian Congo as a remorseful gesture of a "nervous state."12 Hunt argues that the maternal and infant clinics established throughout the colony were a central part of the projection of the Belgian Congo as a model colony. ${ }^{13}$ In opposition to Young, Christophe Bonneuil and James Scott see welfare and development as a policy that underpinned the formation of the state itself. ${ }^{14}$ Both views bring key insights. The federal vision of a health service with its promise of universal access to health was foundational to the nation building aspirations of the Federation's ruling settler elite. At the same time, the perceived benefits of the service were an important means by which the federal government sought to justify, legitimize, and shore up an increasingly beleaguered federation.

The main features of the colonial developmentalist state were an export-oriented infrastructure, an enlarged administrative organization, and a reliance on import and export duties for revenue. ${ }^{15}$ The developmentalist state emerged in Africa in response to

${ }^{12}$ Crawford Young, The African Colonial State in Comparative Perspective (New Haven: Yale University Press, 1994), 208-213; Nancy Hunt, A Nervous State: Violence, Remedies, and Reverie in Colonial Congo (London: Duke University Press, 2016), 8-11. ${ }^{13}$ Hunt argues that there existed two tracks or guises in the Congo, the biopolitical and the nervous. The former worked to promote life and health while the second attempted to police and contain therapeutic insurgencies. Nancy Hunt, A Nervous State: Violence, Remedies, and Reverie in Colonial Congo (London: Duke University Press, 2016), 8-11. ${ }^{14}$ Christophe Bonneuil, "Development as Experiment: Science and State Building in Late Colonial and Postcolonial Africa, 1930-1970," Osiris, 15 (2000), 259, fn.5; James Scott, Seeing Like a State: How Certain Schemes to Improve the Human Condition have Failed (New Haven: Yale Univ. Press, 1998).

${ }^{15}$ Frederick Cooper describes the late colonial developmentalist state as a gatekeeper state. A gatekeeper colonial state is one in which sovereignty rests outside the territory, the colonial apparatus controls the flow of resources in and out of the colony, and decides 
the Great Depression. ${ }^{16}$ The extreme hardships of the 1930s drove imperial governments to implement policies designed to harness the resources of their colonies to alleviate domestic unemployment and rejuvenate economic activity in the metropole.

Development, distinguished by increased state planning and regulation, meant colonial governments assumed greater control of the colonial economy. ${ }^{17}$ It also represented colonialism at its most intrusive.

The shift to a developmental ethos was also a response to widespread labor strikes in many parts of the empire. In Northern Rhodesia, the African miners' strike of 1935 engulfed the entire Copperbelt and mobilized many sections of the population, including women. ${ }^{18}$ When riots erupted in the West Indies, the Colonial Secretary warned that social services had to be developed if Britain wanted to keep her colonies. ${ }^{19}$ In the aftermath of the Second World War, development ideology contained a moral dimension in that it also encompassed the idea of African uplift, an expression of the older civilizing mission. ${ }^{20}$ The widespread poverty and hunger of the 1930s also influenced international health organizations' ideas about the social and economic determinants of disease. ${ }^{21}$ At the same time, Britain and France realized that greater attention to the social welfare of their colonial subjects was vital if they were to harness the economic potential of their

who gains access to those resources. Frederick Cooper, Africa since 1940: The Past of the Present (Cambridge: Cambridge University Press, 2002), 5.

16 Bonneuil, "Development as Experiment," 259.

${ }^{17}$ Ibid.

${ }^{18}$ Frederick Cooper, Africa since 1940, 30.

${ }^{19}$ Frederick Cooper, "Modernizing Bureaucrats, Backward Africans, and the

Development Concept," in International Development and the Social Sciences, edited by F. Cooper and R.M. Packard, Berkeley: University of California Press, 1997), 67.

${ }^{20}$ Randall Packard, A History of Global Health: Interventions into The Lives of Other Peoples (Baltimore: John Hopkins University Press, 2016), 93.

${ }^{21}$ Ibid., 47-89. 
colonies. As Frederick Cooper notes, development was an ideology based on the "need to find a progressive basis for continued colonial rule., 22

The moral dimension of development reflected the universal language expressed in a number of post war, rights-based declarations such as the 1948 Universal Declaration of Human Rights. These encompassed a moral imagination, a process by which people envision possibilities for a morally better world. ${ }^{23}$ For white settlers in the Federation, these possibilities crystallized around a future in which a white civilization in Central Africa was viable. Africans were part of this future but their place was clearly defined in terms that maintained a much older settler colonial framework of segregation and subordination. In this view, healthcare for Africans was an important part of development and African advancement but was also separate from provision for whites. Importantly, healthcare was a benefit to be extended to Africans by Africans but always under supervision from supposedly superior white medical staff. For their part, Africans imagined a different future. For some, the start of federation, with its promises of partnership and the development of a multiracial society, appeared to offer possibilities. For others it was a period to be endured or resisted. The ability of the Federal Health Service to provide health care or to offer avenues of employment to Africans became a means by which Federation itself could be judged.

After the Second World War, African activists increasingly used European ideological constructs and the language of development to argue for more rights in the

\footnotetext{
${ }^{22}$ Frederick Cooper, "Modernizing Bureaucrats, Backward Africans, and the Development Concept," 70.

${ }^{23}$ Julie Livingston, Debility and the Moral Imagination in Botswana (Bloomington: Indiana University Press, 2005), 20.
} 
colonial state. Trade union workers in Nigeria laid claim to citizenship rights by insisting on European ideas of men as head of households and providers for their families. They used the ideology of the universal worker as the male breadwinner to argue for wage and cost of living increases that would "allow men to build respectable households in which they provide for their children. ${ }^{24}$ Michael West has argued that the first half of the federal decade was one in which Southern Rhodesian middle class Africans sought integration with white settler society on the basis that they were "civilized men" by virtue of education and lifestyle. ${ }^{25}$ West asserts that by the end of 1958 , elite and middle class Africans realized that access to white settler society was a pipedream and turned to nationalist politics. ${ }^{26}$ While health does not feature at all in West's analysis, my research suggests that access to biomedicine was a central concern for elite Africans illustrating, perhaps, that West's analysis of the middle class could be extended beyond education, domesticity, and housing to include African demand for health care and access to health professions.

The federal vision of health reflected the nascent development ideology but also post war ideas about biomedicine's ability to conquer disease. With the memories of the Second World War still fresh and the threat of a nuclear war growing more insistent, world leaders looked to create a new world order predicated on economic health, financial stability, and the improved health of world populations. ${ }^{27}$ Furthermore, the

\footnotetext{
${ }^{24}$ Lisa A. Lindsay, "Domesticity and Difference: Male Breadwinners, Working Women, and Colonial Citizenship in the 1945 Nigerian General Strike," The American Historical Review 104:3 (1999), 812.

25 West, The Rise of an African Middle Class, 196.

26 Ibid., 212-216.

27 Packard, A History of Global Health, 93.
} 
rapid wartime development of medical technology appeared to promise that the improvements in health necessary to underpin development could be achieved without the need to attend to the broader social determinants of health. ${ }^{28}$ The World Health Organization encapsulated this enthusiasm in its draft constitution, which said that it would "stimulate and advance work to eradicate epidemic, endemic and other diseases." 29 The WHO appeared to offer a way to conquer disease. ${ }^{30}$

By the 1950s, the optimism surrounding the ability of biomedicine to banish disease fostered a new set of values and ideas, a moral order, of contemporary biomedicine based on a reductionist rationality that privileged the knowledge of the human body and therefore the authority of the medical practitioner reliant on technological innovations. For the practice of medicine, the moral order prioritized the hospital, the clinic, or the laboratory as sites in which medical knowledge could be furthered through the examination of the human body. ${ }^{31}$ The emerging moral order of biomedicine eschewed the broader social determinants of health such as poverty, the environment, and social wellbeing. Healthcare in the federal era reinforced this moral order because the federal government's takeover of health separated health provision from that of social welfare and environmental sanitation.

\footnotetext{
${ }^{28}$ Ibid., 105.

${ }^{29}$ The WHO, Article 2 section G, qtd in Bob H. Reinhardt, The End of a Global Pox: America and the Eradication of Smallpox in the Cold War Era (Chapel Hill, NC: The University of North Carolina Press, 2015), 31.

${ }^{30}$ Bob H. Reinhardt, The End of a Global Pox: America and the Eradication of Smallpox in the Cold War Era (Chapel Hill, NC: The University of North Carolina Press, 2015), 32 .

${ }^{31}$ Claire Wendland, A Heart for the Work: Journeys through an African Medical School (Chicago: University of Chicago Press, 2010), 15-18.
} 
In the Federation, development ideology and a moral order of biomedicine were articulated within a framework of settler colonialism. The optimism about the eradication of tropical diseases such as malaria, fuelled by wartime success with DDT, led to ideas that the Central African Federation could become like the United States, based at least in part on the belief that biomedicine could make the region a "'white man's country' free of tropical disease. ${ }^{32}$

During the federal decade, the Federal Health Service maintained a celebratory narrative of success. The federal takeover of health allowed the federal government to project an image of the Federation as a rapidly developing, progressive nation that had brought significant benefits to the standard of living of African people. A key part of this narrative was that the Federation had developed a health service that surpassed any on the African continent. This was part of a widespread federal campaign at home and abroad designed to legitimize the Federation and white settler rule.

Throughout its short existence, the Federal Health Service struggled to live up to its promise of benevolent biopower. ${ }^{33}$ It was hampered by a colonial legacy that had privileged health care for Europeans and productive African labor. In addition, there had been reluctance on the part of colonial governments to invest in medical training programs for Africans, meaning that medical services remained reliant on the ability to recruit expatriate doctors and nurses. This had the result of creating an enduring shortage

32 JoAnn McGregor and Terence Ranger, "Displacement and Disease: Epidemics and Ideas about Malaria in Matabeleland, Zimbabwe, 1945-1996." Past \& Present, 167 (2000): 204.

33 Jean-Germain Gros, Healthcare Policy in Africa: Institutions and Politics from Colonialism to the Present (London, Rowman \& Littlefield, 2016), 39-78. 
of what Paul Farmer has termed the four S's: staff, space, stuff, and systems. ${ }^{34}$ The federal service, like many initiatives in the late colonial period (and in international and global health) purported to benefit the African people. Instead, many of its policies and practices served to preserve and maintain existing inequities of health. The health service became increasingly beleaguered from 1959 onwards as political turmoil engulfed the entire region when African nationalists actively campaigned for independence. As such, my work underscores that effective healthcare provision is reliant on the existence of solid foundations of infrastructure, proper training, and equitable health care policies. Attending to the rhetoric and realities of healthcare provision in the Central African Federation illustrates how otherwise progressive ideas about access to health provision and medical careers for African people could serve to maintain a settler colonial order. Federal healthcare policies and practices perpetuated the earlier colonial inequities of healthcare provision. In addition, despite protestations to the contrary, federal health policies tended to marginalize healthcare provision in the northern territories contributing to the fragile health systems that Zambia and Malawi inherited when they attained independence.

\section{Settler Colonialism}

The Federal Health Service operated within a wider context of settler ideology. Settler colonialism differs from colonialism. Lorenzo Veracini has argued that colonialism and settler colonialism are antithetical formations even as they remain

\footnotetext{
34 Paul Farmer and Joia Mukherjee, "Ebola's Front Lines,” Boston Globe, September 24, 2014, https://www.bostonglobe.com/opinion/2014/09/23/responding-ebola-countriesneed-staff-stuff-space-and-systems/.
} 
compatible. ${ }^{35}$ While colonialism aims to permanently subordinate the colonized, settler colonialism seeks to erase the colonized through physically elimination, displacement, erasure of cultural practices, assimilation, or amalgamation. ${ }^{36}$ As Patrick Wolfe observed, this erasure is rooted in the settlers' demand for land; thus, "territoriality is settler colonialism's specific, irreducible element. ${ }^{, 37}$ For Wolfe, settler colonialism's dominant feature is not exploitation of the indigene but replacement. Veracini argues that erasure, the removal either literally or conceptually of the indigene from settler spaces, takes place through various strategies of transfer. ${ }^{38}$

In Southern Rhodesia a diverse number of strategies were used to literally and conceptually remove the indigene. The most obvious of these was the creation of African Reserves and the use of pass laws to control and limit African mobility. ${ }^{39}$ Other strategies were also important to make indigenous Africans disappear. A central tenet of Rhodesian heritage was that the first settlers, the Pioneer Column, encountered an empty land. ${ }^{40}$ In reality, this was a misreading of African land usage, African history, and the dislocations of colonial conquest, but became an important justification for land alienation. ${ }^{41}$

Furthermore, given that settlers bring with them a sense of entitlement of

\footnotetext{
35 Lorenzo Veracini, Settler Colonialism: A Theoretical Overview (New York: Palgrave Macmillan, 2010), 12.

${ }^{36}$ Lorenzo Veracini, “Introducing," Settler Colonial Studies, 1,1 (2011), 2.

37 Patrick Wolfe, "Settler Colonialism and the elimination of the native," Journal of Genocide Research 8, 4 (2006), 387 - 409.

38 Veracini, Settler Colonialism, 33-49.

39 The 1930 Land Apportionment Act, the "Magna Carta of racial segregation," divided the land in Southern Rhodesia along racial lines. The best land was permanently alienated from African ownership. 51 percent of the land was given to 51,000 white settlers while one million Africans received less than 30 percent. Mlambo, A History of Zimbabwe, 61. 40 The Pioneer Column claimed the territory for Britain in 1890. Ibid., 43-44. 41 James Fairhead, and Melissa Leach, Misreading the African Landscape: Society and Ecology in a Forest-savanna Mosaic (Cambridge: Cambridge University Press, 1996).
} 
sovereignty or right to rule, the denial of a deeper African past was an essential part of asserting that right. To this end, the white settler elite re-imagined the relics of Great Zimbabwe, a large and powerful kingdom between 1270 and 1550, as the work of unknown Caucasians. ${ }^{42}$ The denial of an African past was also evident in the sphere of health where the benefits of biomedicine as an agent of uplift out of savagery and barbarism were marshaled in an attempt to obscure and repress a vibrant African heritage of health and healing. ${ }^{43}$

Veracini rightly observes that Southern Rhodesia (along with Kenya) was always an imperfect settler colony given the inability of the white settlers to "supercede the conditions of its operation. ${ }^{, 44}$ It neither founded an independent nation (even though it attained a certain level of political autonomy from the metropole), nor was it able to effectively repress, co-opt, or extinguish a numerically superior African population. However, the white settler ruling elite did establish a Southern Rhodesian society in which the characteristics of a model settler state were much in evidence. ${ }^{45}$ The de facto autonomy granted to the Southern Rhodesian government in 1923 gave the Legislative

\footnotetext{
${ }^{42}$ Mlambo, A History of Zimbabwe, 19-21.

${ }^{43}$ The literature on African healing systems is vast but for a comprehensive introduction to the enduring multipluralism of African approaches to medicine, see: -Steven Feierman, "Struggles for Control: The Social Roots of Health and Healing in Modern Africa," African Studies Review 28, 2/3 (1985), 73-147.

${ }^{44}$ Veracini argues that settler colonialism is most visible in Rhodesia and Kenya because they did fail. The successful settler state closely resembles the metropole of its origin. Lorenzo Veracini, "Introducing," 3.

${ }^{45}$ Ronald Weitzer has argued that a settler society strives for three pillars that underpin the social and political structures of a model settler state: political autonomy from the metropole, the consolidation of control over the indigenous population, and the maintenance of settler caste solidarity and state cohesion. Ronald JohnWeitzer, Transforming Settler States: Communal Conflict and Internal Security in Northern Ireland and Zimbabwe, (Berkeley: University of California Press, 1990), 25-28.
} 
Council considerable political authority and coercive power. It allowed the government to enact discriminatory legislation of land appropriation and erect a color bar. ${ }^{46}$ In addition, pass laws, discriminatory policies in health, education, welfare, housing, and land assured the control and repression of the indigenous population. At the same time, a colonial hierarchy and segregation of social spaces together with the development of an elaborate racial etiquette established a settler caste and helped to forge an idea of Southern Rhodesia as a "white man's country.",77

\section{Colonialism, Gender, and Education}

Europeans brought to Africa notions of gender roles that reflected Victorian Christian society in nineteenth century Britain. Victorian Christian values embraced hard work, duty, and deference to authority as essential to both spiritual salvation and a wellordered society. In this distinctly patriarchal social order, masculinity was embodied in the idea of man as the authoritative head of the family with his subordinate wife having primary responsibility for raising dutiful, deferent daughters, and respectful but assertive sons. Encompassing ideas of separate gendered spheres of influence, a woman's place was in the home, while a man's was in the workplace. Importantly, in western thought, women's work was not seen as economically productive. ${ }^{48}$

\footnotetext{
${ }^{46}$ It is notable that although the British government retained a power of veto over legislation affecting Africans, it never exercised that reserved power.

47 On racial etiquette in colonial Zimbabwe, see Allison Kim Shutt, Manners Make a Nation: Racial Etiquette in Southern Rhodesia, 1910-1963, (Rochester, NY: University of Rochester Press, 2015).

48 Dorothy L. Hodgson, "Pastoralism, Patriarchy and History: Changing Gender Relations among Maasai in Tanganyika, 1890-1940," JAH 40:1 (1999), 57.
} 
In the colonial setting, Victorian Christian ideas articulated a gendered, racialized hierarchy in which African men, while subordinated to European men and women, were supposed to control African women while being the sole mediator with the colonial state. ${ }^{49}$ The main ways in which African males intersected with the colonial state was through polices of taxation and productive labor. The imposition of taxes and monetization of African economies created a male labor force, which by working for Europeans, would provide the productive labor needed to build and maintain the colonial economy. Women were required to stay within the domestic sphere and their function was the reproduction of the labor force. ${ }^{50}$ Thus the ideal African woman was constructed as one who remained within the confines of rural African villages.

The gendered colonial labor policies intersected well with the missionary project. The "civilizing" mission included inculcating values of hard work, discipline and obedience. However, while missionaries shared the colonial states' ideas about the restriction of African women to the domestic sphere, they also realized that it was essential to the evangelizing mission that African motherhood be based on Christian values of "the 'civilizing' influences of hard work, discipline, and obedience to [male] authority." ${ }^{, 51}$ This meant that as future mothers, African girls required exposure to western values. Missionaries and colonial governments, then, were in agreement about the role of education for Africans. While boys were to be taught skills to enable them to

${ }^{49}$ Barbara Cooper, "Women and Gender" in The Oxford Handbook of Modern African History, edited by John Parker and Richard Reid (Oxford, 2013), 349. ${ }^{50}$ Elizabeth Schmidt, Peasants Traders and Wives: Shona Women in the History of Zimbabwe, 1870-1939 (Portsmouth, NH: Heinemann Educational Books, 1992), 129. ${ }^{51}$ Ibid. 
become useful contributors to the colonial economy, girls were to be taught to be homemakers. ${ }^{52}$

The education curriculum for boys was designed to allow them to interact with the colonial state. As such, boys received English language instruction, literacy skills, and training for trades such as driving and carpentry. Conversely, a typical curriculum for girls at mission schools was based on teaching domestic skills such as cooking, sewing, and doing laundry. Girls were to be actively discouraged from academic work although if parents agreed to pay extra fees, some basic literacy training would be provided. African girls were much less likely to receive any English language instruction because it was not seen as a priority among mission educators. ${ }^{53}$

Influences within African societies also tended to restrict the amount of schooling African girls received. The gendered division of labor within many African communities meant that women and girls were primary providers of agricultural labor. From an early age, girls helped pound maize, weeded and watered vegetable gardens, and helped to protect crops from foraging birds. Child productive labor was something African families could ill afford to lose and consequently it was usually girls who were kept out of school. ${ }^{54}$ In addition, many African elders resisted mission education for African girls because they believed it disrupted the social order and posed an economic threat to

\footnotetext{
52 For a good example of the colonial state's commitment to this form of gendered education see Abosede A. George, "Delinquents to Breadwinners and Hawkers to Homemakers: Gender, Juvenile Justice, and Reform in the Welfare City," in Making Modern Girls: A History of Girlhood, Labor, and Social Development in Colonial Lagos (Ohio, 2014), 171-200.

53 Schmidt, Peasants Traders and Wives, 133. 54 Nancy Rose Hunt, A Colonial Lexicon of Birth Ritual, Medicalization, and Mobility in the Congo (Durham: Duke University Press 1999), 12; Schmidt, Peasants Traders and Wives, 142.
} 
parents. Educated girls were more independent and more likely to refuse to marry the man chosen for them. This usurped parental authority but also meant that parents would have to return the bridewealth they had received. In addition, the domestic training that girls received at mission schools meant that parents received no return on their substantial investment in education. Whereas boys were likely to acquire jobs associated with "colonial middles" such as clerks, parents believed that girls would "only" get married. ${ }^{55}$ Even when girls did gain access to education, these African influences tended to mean that girls often did not complete many years of education. The result was a gendered education curriculum that for much of the colonial period worked to exclude many women from access to healthcare careers.

\section{Colonial and Mission Medicine}

A formidable body of scholarship exists on the history of colonial medicine in Africa. Much of this scholarship has tended to focus on the earlier colonial period. Colonial conquest was a violent process that increased the disease burden of African people. ${ }^{56}$ The devastating effects of the consequent epidemics and social dislocation have provided fertile ground for scholars, particularly those who have viewed colonial

\footnotetext{
55 Ibid., 140-141.

56 It is believed that in excess of 200,000 died in epidemics of trypanosomiasis around Lake Victoria in East Africa during this period and smallpox within a context of famine claimed many lives in Kenya. Marc Dawson and Helen Tilley, "Ecologies of Complexity: Tropical Environments, African Trypanosomiasis, and the Science of Disease Control in British Colonial Africa, 1900-1940," Osiris 19 (2004): 21-38. For further scholarship on early colonial responses to epidemics see Maryinez Lyons, "From 'Death Camps' to Cordon Sanitaire: The Development of Sleeping Sickness Policy in the Uele District of the Belgian Congo, 1903-1914 1," The Journal of African History 26, 1 (1985): 69-91.
} 
medicine as a tool of empire. ${ }^{57}$ The post Second World War period has attracted rather less attention as scholars turned their attention to the impact of global health interventions and of international finance policies on independent African nations' health systems.

Even less attention has been paid to the history of colonial healthcare in the three colonies that made up the territory of the Central African Federation.

It can also be argued that South Africa has attracted the lion's share of scholarly interest in the history of health in Southern Africa, particularly for those scholars who advocated a political economy approach. ${ }^{58}$ These scholars argued that provision of health for Africans was closely linked to the needs of the colonial capital economy. Colonial industrialists profited from a political economy that provided the bare minimum of healthcare and shifted the social costs of production onto the African societies that provided the labor. ${ }^{59}$ Scholars of South African medical history have also written about the way in which matters of health have informed colonial government policy. Maynard Swanson argued that a sanitation syndrome emerged in Cape Town in response to the plague epidemic of 1901. White South Africans in the Cape Colony came to believe that

\footnotetext{
57 The classic examples of this approach include David Arnold (ed.), Imperial Medicine and Indigenous Societies (Manchester: Manchester University Press, 1988); Roy MacLeod and Milton Lewis (eds), Disease, Medicine and Empire: Perspectives on Western Medicine and the Experience of European Expansion (London \& New York: Routledge, 1988).

58 Randall M Packard, White Plague, Black Labor:Tuberculosis and the Political Economy of Health and Disease in South Africa, (Berkeley: University of California Press, 1989). Shula Marks and Neil Anderson, "Industrialization, Rural Health and the National Health Service Commission in South Africa." In eds. Steven Feierman and John Janzen, The Social Basis of Health and Healing in Africa (Berkeley: University of California Press, 1992), 131-174. For East Africa see: Meredith Turshen, The Political Ecology of Disease in Tanzania (New Brunswick: Ruthgers, 1984). ${ }^{59}$ Livingston, Debility and the Moral Imagination in Botswana (Bloomington: Indiana University Press, 2005), esp. chapter 3.
} 
European health was best ensured by a policy of residential segregation. ${ }^{60}$ The ideology of segregation is important because it informed healthcare policies in Southern Rhodesia throughout the colonial period and remained the basis upon which healthcare for Africans and Europeans was provided during the period of federation.

Histories of colonial government medical services in Central Africa are sparse, and, for the most part, dated. They are part of a genre that generally emphasizes the supposed benevolence of the colonial authorities and the contribution of western medicine to the civilizing mission of empire ${ }^{61}$ While acknowledging the moral impulse driving the federal government's desire to expand healthcare services, I aim to highlight the ways in which doing so furthered white settler aims and ambitions.

The most extensive history of health in the territories of the Central African Federation has been that of missionary medicine. ${ }^{62}$ This is unsurprising given the importance of the mission sector in providing health for African societies. As Megan Vaughan has noted, missions provided the majority of medical care for Africans in the

${ }^{60}$ Maynard W. Swanson, "The Sanitation Syndrome: Bubonic Plague and Urban Native Policy in the Cape Colony, 1900-1909," The Journal of African History 18, 3 (1977), 387-410.

${ }^{61}$ Michael Gelfand, A Proud Record (Salisbury (Harare): Government Printer for the Federal Bureau of Information, 1960); Michael Gelfand, A Service to the Sick (Harare: Mambo Press, 1976); Colin Baker, "The Government Medical Service in Malawi: An Administrative History, 1891-197," Medical History 20 (1976): 296-311.

${ }^{62}$ Walima T. Kalusa, "Language, Medical Auxiliaries, and the Reinterpretation of Missionary Medicine in Colonial Mwinilunga, Zambia, 1922-51," Journal of Eastern African Studies, 1 (2007): 57-78; Linda Beer Kumwenda, "The Training of Female Medical Auxiliaries in Missionary Hospitals in Northern Rhodesia, 1928-1952." Social Sciences and Missions, 16 (July 2005), 122; Charles Good, The Steamer Parish: The Rise and Fall of Missionary Medicine on an African Frontier (London, University of Chicago Press, 2004). 
colonies at least until at least the post Second World War period. ${ }^{63}$ Early histories of mission medicine emphasized the proselytizing aim of missionary work. In this formulation missionary medicine was an evangelical weapon as well as a tool with which to inculcate western norms and values. ${ }^{64}$ The problem for medical missions was that biomedicine for much of the early part of the colonial period was hopelessly inadequate for the increased disease burden that European colonizers had imposed through conquest, war, social dislocation, and migrant labor policies. Africans responded by embracing biomedicine when it worked, by incorporating missionary medicine into their own healing practices, and by walking away from treatment that appeared ineffective. ${ }^{65}$

More recently, scholars have investigated the ways in which missions and colonial governments shared the responsibility for providing health care. This is contested territory with some scholars arguing that any collaboration was limited to combating epidemics or treating specific diseases such as leprosy. ${ }^{66}$ Others say that government funding was vital for missions to carry out their work. In this formulation missions and governments collaborated in a "public-private partnership.."67 Scholars

\footnotetext{
${ }^{63}$ Megan Vaughan, "The Great Dispensary in the Sky: Missionary Medicine," in Curing their Ills: Colonial Power and African Illness (Stanford University Press, 1991), 56. ${ }^{64}$ Ibid., 55-77.

${ }^{65}$ For a fuller discussion on the relationship between biomedicine, missionary medicine, and African healing practices see: Steven Feierman, "Explanation and Uncertainty in the Medical World of Ghaambo," Bulletin of the History of Medicine 74, 2 (2000): 317-44. ${ }^{66}$ Good, The Steamer Parish, 337-345.

${ }^{67}$ Jennings argues that the Colonial Service relied on collaboration with non-state actors, especially missions, to provide even a semblance of "national" health care even in the late colonial period, a period when colonial states are considered to have played a bigger role in providing medical services. Michael Jennings, "Cooperation and competition: missions, the colonial state and constructing a health system in colonial Tanganyika," in ed. Anna Greenwood Beyond the State: The Colonial Medical Service in British Africa (Manchester: Manchester University Press, 2016), 153.
} 
have shown that even in the early colonial period, missions relied on some limited government funding and received patient referrals while recommending some patients, often those with mental illness, to the fledgling colonial service.$^{68}$ At the same time, the boundary between medical mission work and government service was permeable. Doctors moved between the two and generally enjoyed better pay and conditions within the colonial medical service. ${ }^{69}$ Cooperation between missions and the government continued to be important in the federal period. The federal government increased funding for missions but also became more involved in the ways in which they provided care and training. As a result the medical mission sector in Central Africa lost much of its independence during this period.

The experiences of African medical workers have been the subject of much scholarly attention in recent years. Early histories concentrated on the role of medical auxiliaries in disseminating western Christian values. ${ }^{70}$ This has been followed by scholarship examining the ways in which Africans working as aides, assistants, orderlies, and midwives have played a significant part in translating and re-interpreting biomedicine. In this view, Africans were not agents of cultural annihilation but

\footnotetext{
${ }^{68}$ Markku Hokkanen, "The government medical service and British missions in colonial Malawi, c1891-1940: crucial collaboration, hidden conflicts," in Beyond the State: The Colonial Medical Service in British Africa, edited by Anna Greenwood, (Manchester: Manchester University Press, 2016), 43.

69 Ibid.

${ }^{70}$ Megan Vaughan, "Health and Hegemony: Representation of Disease and the Creation of the Colonial Subject in Nyasaland" in Contesting Colonial Hegemony: State and Society in Africa and India, eds. Dagmar Engels and Shula Marks (London and New York: British Academic Press, 1994), 173-201.
} 
interpreters who imbued missionary medicine with local meaning. ${ }^{71}$ Scholarship on advanced medical training of Africans is relatively sparse reflecting its limited availability in the tropical colonial context. ${ }^{72}$

The question of whether to train African women as registered, professional nurses emerged in Southern Rhodesia amidst a severe shortage of white professional nurses between the mid 1930s and $1950 .{ }^{73}$ This was nearly half a century later than in South Africa where racial anxieties about white women tending black bodies paved the way for the entrance of African women into the South African nursing profession. Shula Marks has shown how the training of African medical staff in South Africa complicated and threatened the prevailing colonial medical hierarchy, which always placed white medical staff above black and gave doctors seniority over nurses. ${ }^{74}$ The entrance of African doctors into clinical workplaces and the possibility of black nurses having seniority over white nurses inverted and subverted this hierarchy. ${ }^{75}$ The tensions and conflicts that Marks points to are also apparent in Southern Rhodesia in the later federal period when the first African doctors and qualified nurses began working in the government service.

The shortage of white nurses in Southern Rhodesia in the 1940s was due to a combination of healthcare policies, settler colonial ideology, increased urbanization, and

${ }^{71}$ Walima T. Kalusa, "Language, Medical Auxiliaries, and the Reinterpretation of Missionary Medicine," 57-78.

72 One exception to this is John Iliffe's history of the medical profession in East Africa. John, Iliffe, East African Doctors: A History of the Modern Profession (Kampala, Uganda: Fountain Publishing, 2002).

${ }^{73}$ Clement Masakure, "One of the most serious problems confronting us at present": Nurses and government hospitals in Southern Rhodesia, 1930s to 1950," Historia, 60, 2 (2015), 109-131.

${ }^{74}$ Shula Marks, Divided Sisterhood: Race, Class and Gender in the South African Nursing Profession (Basingstoke, UK: The Macmillan Press, 1994).

${ }^{75}$ Ibid., 140 
wartime military demands. ${ }^{76}$ Clement Masakure contends that the shortage directly contributed to plans for the training of African state registered nurses. ${ }^{77}$ These plans came to fruition during Federation, a period Masakure doesn't examine in his scholarship. My analysis moves his story into the federal decade and expands it to encompass medical officers and auxiliary staff. An important distinction between my work and his is that during federation, the color bar was supposed to be lifting and that the ideology of professional nursing as the province of white women had changed. The federal health department asserted the importance of black qualified nurses to its aspirations to provide a national health service. By the 1950s it was not a case of should they train African professional nurses but when and where. The effect of these decisions and those relating to the building of the medical school was to marginalize the northern territories in ways that reverberated in the years after the Federation collapsed and Malawi and Zambia gained their independence.

Senior health officials in the federal Ministry of Health imagined a medical community united in purpose and vision. ${ }^{78}$ Federating health brought together colonial medical personnel that differed in opinion, in color, and did not always follow imperial instructions. ${ }^{79}$ I attempt to capture some of that diversity by attending to the actions of European and African medical workers during federation. Furthermore, government

\footnotetext{
${ }^{76}$ Masakure, "One of the most serious problems confronting us at present," 109-131. 77 Ibid., 130.

78 Anna Crozier has examined how the doctors of the Colonial Medical Service formed a medical community with a shared identity based on background, education, and motives for joining the service. Anna Crozier, Practising Colonial Medicine: The Colonial Medical Service in British East Africa (London: I.B. Tauris \& Co, 2007).

${ }^{79}$ Anna Greenwood (Crozier), "Introduction: looking beyond the state," in Beyond the State: The Colonial Medical Service in British Africa, Manchester: Manchester University Press, 2016, 1-18.
} 
health departments were often short of administrative staff affording colonial medical officers a degree of latitude in their work that they would not have enjoyed in Britain. ${ }^{80}$ As such, I examine how European medical doctors and nurses grappled with the practicalities of transferring out of the colonial medical service to an uncertain future in the federal Ministry and whether federation actually brought about better opportunities for African medical personnel within a political climate supposedly predicated on "multiracial partnership."

The theme of "multiracial partnership" is central to the only scholarship that investigates healthcare within the Federation. Brendon Marsh uses health provision to examine the degree to which multiracial partnership was an attainable reality. ${ }^{81}$ Marsh concludes that partnership was more rhetoric than actuality based on an evaluation of health spending and lack of training for medical doctors, arguing, "one African doctor and a handful of medical students [at external medical schools] do not a 'partnership' make. ${ }^{\prime 2}$ Marsh rightly points out that the Federal Health Service failed to carry out any real policy of partnership. It neither invested enough in infrastructure or in training. My work expands on this to examine the effect of this failure, placing it within a longer arc of colonial failures to build foundations of health and considering the ramifications for healthcare in the newly independent nations of Malawi and Zambia. I argue that the senior medical officials in the Federal Health Service had a particular vision of what a

80 Ibid.; Glen Ncube, "The Making Of Rural Healthcare In Colonial Zimbabwe: A History Of The Ndanga Medical Unit, Fort Victoria, 1930-1960s," Ph.D diss, University of Cape Town, 2012, 9-10.

${ }^{81}$ B.D.Marsh, “"Multiracial Partnership' and African Health Care in the Central African Federation" in eds. Toyin Falola and Mathew Heaton, Health, Knowledge, and Belief Systems in Africa (Durham, N.C. : Carolina Academic Press, 2008), 261-276. 82 Ibid., 275. 
health service should look like. This vision did not preclude the supposedly progressive language of "partnership" but manipulated it to maintain a colonial medical order predicated on white settler domination.

In addition, Marsh's analysis does not consider the extent to which a federated health service contributed to the nation building aspirations of white settlers in Central Africa. Indeed, his assertion that health "went to the Federation" suggests that the British government gave control of health to the federal government. What is clear from the sources is that far from bestowing health on the federal government, the British officials were either largely unaware that health as a federal function had been discussed or did not think health would be anything other than a territorial matter given that it was considered integral to Africans' day to day existence. ${ }^{83}$ The federal government appropriated control of the service as part of an ongoing plan to build a white state in Africa and prove itself ready for Dominion status within the British Empire. My analysis, therefore, allows for an appreciation of the desire of the white settler ruling elite to use federation as a means of state-building and foregrounds health in this process.

\section{The Sources}

The primary evidence that has informed this thesis has come from a variety of sources. Reflecting the realities of carrying out a project on African history from outside the continent, my sources are heavily weighted to those from official archives that were readily accessible. The fortuitous discovery of the complete set of departmental records

83 This is evident in the comments attached to TNA CO 1015/634 and TNA CO $1015 / 1090$. 
relating to Nyasaland and Southern Rhodesia for their entire colonial periods made this project viable. While these sources only present one view, that of the colonial medical officials, it is possible to glean a more complex interpretation when read against the grain and in conjunction with other sources.

The departmental reports were supplemented by further archives consulted in visits to the British National Archives and the British Library in London. Access to the full set of the debates of the Federal Assembly allowed me to uncover an African perspective albeit one that was limited to an elite class of African MPs. This African perspective was further enhanced by the acquisition of a memoir written by a Malawian doctor. Austin Mkandawire trained as a medical assistant in Nyasaland immediately prior to federation and worked in the Federal Health Service until leaving to continue his studies in Britain in 1958.

Memoirs, however, can be problematic as sources in historical research. They are written with hindsight, with a specific audience in mind, and with a definite agenda and so need to be used with caution. I was fortunate, therefore, to uncover the papers of a colonial doctor that covered the same time period and geographical location during a visit to the National Library of Scotland. The doctor was a member of the colonial medical service in Nyasaland and was seconded into the federal government service in 1954. The papers consist of weekly letters home to family in Scotland and so represent a contemporary record of life in the federal service. Included with the papers were two lengthy letters written by an African medical worker to the doctor after he left Africa at the end of 1957. The letters give a glimpse into the difficulties of the Federal Health Service from outside the official federal reports. 
The wealth of official reports and government papers was augmented by the examination of medical journals and periodicals of the period. The Central African Journal of Medicine was particularly useful for highlighting some of the tensions and conflicts between the government and the private service at the time.

An important point to note is that there was an uneven distribution of sources about the three colonies of the Central African Federation. In particular, sources for Zambia, formerly Northern Rhodesia, were relatively scant. This was not helped by the dearth of scholarship on the colony's history of healthcare. An email conversation with Walima Kalusa, one of the few historians to have written about health and disease in Zambia, confirmed that historians have generally overlooked this aspect of the nation's past.

\section{A note on terminology}

In this thesis I make a distinction between professionally trained medical workers and auxiliaries. In practice, there was significant overlap. For example, a medical assistant or hospital assistant working in a small, rural hospital or clinic would have had considerable autonomy because professionally trained doctors only visited these facilities sporadically. The demarcation is especially complex with regard to nursing. As such I have tried to refer to African auxiliary nurses as nursing orderlies, or simply as auxiliaries, to distinguish them from nurses who had undergone professional state registered training. Medical auxiliaries encompassed a broad range of functions including medical assistants, hospital assistants, nursing orderlies, medical aides, African midwives, and health demonstrators. When I refer to qualified or professional nurses, I 
am referring to that category of nurse that had undergone a four-year training program leading to state registration. These nurses were overwhelmingly white until the final years of Federation.

\section{Chapter Outline}

The thesis is divided into four chapters. The first examines the history of healthcare provision prior to the Federation paying particular attention to the gender and racial ideologies underpinning policies related to the provision of African medical training. My focus is on the fragile foundations upon which the Federal Health Service attempted to build and the difficulties the service faced when trying to unify what were three very different health services.

The second chapter examines how health came to be a federal function. I argue that the decision to federate health is best understood within a context of settler nation building. I further argue that the process of federating health created suspicion and distrust of the fledgling service and precluded the building of a medical community.

The third chapter moves the story into the Federation years. The chapter focuses on the stark disconnect between the idealized federal vision of healthcare and the shortcomings of that vision in practice.

The final substantive chapter turns to the politically turbulent final years of Federation. This chapter reveals the essential fragility of the Federal Health Service as it struggled to maintain services and failed to hold on to its medical staff. The chapter examines how the federal service responded to a crisis of staffing within the context of a failing federation. This chapter illustrates that despite rhetoric of improved opportunities 
for African access to health careers, the service directed its efforts to recruiting professionals from overseas thus perpetuating a colonial practice of reliance on expatriate expertise. The thesis ends by examining the legacy of federated health for the territorial governments of Southern Rhodesia and the newly independent nations of Zambia and Malawi.

Examining healthcare in the Central African Federation offers a glimpse of healthcare provision in a late colonial developmentalist state. It illustrates the way in which the rhetoric of development and African uplift was articulated within a framework of settler colonialism. Furthermore, it shows the extent to which the maintenance of the colonial order was of primary concern to many of the white settler elite of the Federation. 


\section{Chapter One}

\section{Shaky Foundations of Healthcare in Central Africa}

The provision of health care in the federal era was shaped by the legacies of the colonial past. A robust health care system requires a sound base of infrastructure, training, and equitable healthcare policies. The failure of previous colonial governments to facilitate the development of solid foundations of health meant that the Federal Health Service inherited a fragile health system. In particular the limited attention paid to the training of African medical staff in this earlier period directly contributed to the chronic shortage of medical staff during federation. This chapter examines the extent to which the colonial governments of Central Africa did (or did not) provide healthcare facilities for Africans from the period of colonial conquest to the eve of federation. A major focus is on the failure of colonial governments to build a base of locally trained medical expertise. In particular, it argues that the lack of provision for African medical training in the pre-federation era was a product of a gendered ideology about Africans' roles in colonial society.

\section{Colonial Conquest}

The colonization of Central Africa was a violent process that increased burdens of disease in the African people. In 1889, Britain granted Cecil Rhodes and his British South Africa Company (BSAC) a charter to occupy, govern, and exploit the vast lands north of the Limpopo. In 1890, Rhodes' Pioneer Column marched into the territory and pursued a 
hostile policy of unequal treaties to gain rights to lands believed to be rich in gold, copper, and other minerals. The BSAC was essentially an army of occupation and followed an aggressive policy of land appropriation and forced labor. ${ }^{1}$ Following on the heels of the colonial incursion came a devastating rinderpest epizootic that swept Eastern and Southern Africa in the last decades of the nineteenth century. It virtually wiped out all cattle, destroyed African economies, and created famine. ${ }^{2}$ In Southern Rhodesia, the epidemic contributed to the causes of the Ndebele and Shona uprising of 1896-7 in what became known as the First Chimurenga. ${ }^{3}$ The fragile white settlement almost succumbed until imperial armed reinforcements from South Africa brutally repressed the rebellion. In Nyasaland, colonial occupation occurred in the wake of epidemics of smallpox spread by the wasting frontier of ivory and slave collection that extended from the Swahili coast deep into the African interior in the second half of the nineteenth century. ${ }^{4}$ Formal colonial rule was established in Nyasaland in 1891.

\footnotetext{
${ }^{1}$ Mlambo, A History of Zimbabwe, 36-43.

2 Richard Waller, "Emutai: Crisis and Response in Maasailand, 1883-1902," in The Ecology of Survival: Case Studies from Northeast African History, eds. D. Johnson and D. Anderson, (Boulder, Co. Westview Press, 1998), 73.

${ }^{3}$ In his groundbreaking scholarship, Terence Ranger argued that religious authority united the Ndebele and Shona resistance fighters against the brutal BSAC company rule. His scholarship formed the basis of the foundation myths underpinning African nationalism in the 1960s. Revisionist scholars have questioned the extent of the unified African response to BSAC rule. Terence Ranger, Revolt in Southern Rhodesia, 1896-97: A Study in African Resistance (Evanston. Ill.: Northwestern University Press, 1967). For a discussion of the scholarly debate see Sabelo J. Ndlovu-Gatsheni, "Mapping Cultural and Colonial Encounters, 1880s-1930s," in Becoming Zimbabwe A History from the Precolonial Period to 2008, eds. Brian Raftopoulos, and Alois Mlambo (Oxford: Weaver Press, 2009), 50-58.

${ }^{4}$ The term "wasting frontier" refers to the process in which the search for slaves and ivory was pushed deeper into the African interior as supplies of both dwindled during the nineteenth century. Richard J. Reid, A History of Modern Africa: 1800 to the Present (Hoboken: John Wiley \& Sons, 2011), 45-46.
} 
The early years of colonial rule witnessed further epidemics among African people. Colonial governments responded to the outbreaks with public health campaigns that were coercive and as much to do with asserting state control over human capital as with treating African bodies. ${ }^{5}$ The colonial violence associated with the suppression of epidemics of trypanosomiasis, smallpox, influenza, and venereal disease in Central Africa shaped early African experiences of and responses to biomedicine in general and public health campaigns in particular. ${ }^{6}$ Later complaints by federal health officials of African resistance to vaccination programs or malaria eradication campaigns should be considered in light of these earlier experiences. ${ }^{7}$

From the turn of the century, growing numbers of settlers immigrated to Central Africa. Most were attracted to the rich farmlands in Southern Rhodesia, drawn by the support of government policies that worked to disadvantage African farmers. ${ }^{8}$ In Nyasaland, the colonial government's attempt to introduce settler agriculture largely

\footnotetext{
${ }^{5}$ Lyons, "From 'Death Camps'," 70-71.

6 John McCracken, A History of Malawi 1859-1966, 119; Glen Ncube, 'The Problem of the Health of the Native': Colonial Rule and the Rural African Healthcare Question in Zimbabwe, 1890s-1930, South African Historical Journal, 64, 4 (2012), 821; Jock McCulloch, "The Management of Venereal Disease in a Settler Society: Colonial Zimbabwe, 1900-30," in Histories of Sexually transmitted diseases and HIV Aids in SubSaharan Africa, ed. Philip W Setel, Milton Lewis, and Maryinez Lyons (Westport, Conn: Greenwood Press, 1999), 196-216; Bryan T. Callahan and Virginia Bond, "The Social, Cultural, and Epidemiological History of Sexually Transmitted Disease in Zambia," in Histories of Sexually transmitted diseases, 168-195.

${ }^{7}$ Richard C. Keller, "Geographies of Power, Legacies of Mistrust: Colonial Medicine in the Global Present," Historical Geography 34 (2006), 26-48.

${ }^{8}$ In Kenya, too, the colonial government sought to destroy the ability of African farmers to compete with whites. In Uganda, however, successful African cotton farmers led to the demise of significant European agriculture in the colony. Reid, History of Modern Africa, 197-198. Mlambo, A History of Zimbabwe, 56.
} 
failed. ${ }^{9}$ In Northern Rhodesia, a small number of Europeans settled along the railway line that ran between Livingstone, near Victoria Falls and the towns that would eventually become part of the Copperbelt south of the Katanga mining area of the Belgian Congo.

In common with much of sub-Saharan Africa, early colonial governments in Central Africa were not interested in improving the welfare of African societies. ${ }^{10}$ Healthcare policies privileged European health. Such medical provision as was available served the needs of government employees, missionaries, and early settlers. As elsewhere, a "sanitation syndrome" emerged around 1900 when the idea of African bodies as reservoirs of disease drove a segregationist discourse, informing urban development and housing but also ensuring that the early hospitals were European-only. ${ }^{11}$ The ideology of the pathologized African coalesced with a missionary-driven salvationist discourse promoting the development of missionary medicine across the region. ${ }^{12}$ Without government investment in healthcare, the vast majority of Africans' first encounter with biomedicine was through this missionary endeavor. Missions built rural healthcare infrastructure and trained medical personnel. ${ }^{13}$

The extent to which missions provided medical care varied between individual missions and across the region. The influence of David Livingstone and other early Scottish missionaries led to a sizable presence in Nyasaland. In Northern Rhodesia and

\footnotetext{
${ }^{9}$ An abortive attempt to establish a coffee industry failed in the first decade of the twentieth century. McCracken, A History of Malawi 1859-1966, 75-85.

${ }^{10}$ Good, Steamer Parish, 335.

${ }^{11}$ Swanson, "The Sanitation Syndrome," 387-410. Philip D. Curtin, Death by Migration: Europe's Encounter with the Tropical World in the Nineteenth Century (New York: Cambridge University Press, 1989), 108-109. McCracken, A History of Malawi, 117. 12 Vaughan, Curing their Ills, 55-77.

13 Ibid., 56.
} 
Southern Rhodesia, much larger territories, missions were more scattered. The training of medical assistants in Nyasaland undertaken by the Scottish missions, owed a lot to that mission's ongoing commitment to medical work. In 1910, Dr Caverhill stated, "the [Nyasaland] government has a right to look to us to supply natives skilled in medical and public health work and also to influence the community favorably towards sanitary reform. ${ }^{14}$ In contrast, in Northern Rhodesia, the UCMA and LMS missions prioritized education over medical work, although the UCMA did train limited numbers of orderlies. $^{15}$

The training of medical auxiliaries served practical and ideological purposes. Practically, the African aide was an indispensible member of the medical mission team. In addition to providing much needed health provision capacity, medical aides also functioned as translators, facilitating communication between medical missionaries and their patients. ${ }^{16}$ Ideologically, missions viewed medical aides as important collaborators in their evangelistic endeavors. In particular, missions trained African midwives to counter the social and moral control of elder African women that was considered a major hindrance to the dissemination of Christianity. ${ }^{17}$ Most of the earliest training was in the form of "individual apprenticeship." Missionaries recruited long-term residents, such as

\footnotetext{
${ }^{14}$ Dr. Caverhill, "Report of the Third General Missionary Conference," 1910, 72, qtd in Joyce Smit, "The Training of African Nurses in Nyasaland (Malawi) from 1887 to 1927," Curationis, 11 ( July 1988), 6.

${ }^{15}$ Kumwenda, "The Training of Female Medical Auxiliaries," 122. For the difficulties UMCA medical missions faced with funding due to a lack of commitment to medical work see: Good, The Steamer Parish.

${ }^{16}$ Kalusa, "Language, Medical Auxiliaries, and the Reinterpretation of Missionary Medicine," 57-78.

17 Vaughan, Curing their Ills, 66.
} 
refugees, outcasts, or escaped slaves, or ex-patients who, at that time, often spent many months convalescing at missions. ${ }^{18}$

Early medical training offered at missions was almost exclusively aimed at men. In the African tropical colonial context, nursing was codified as male work until at least the $1940 \mathrm{~s} .{ }^{19}$ Dr. Laws of the Livingstonia mission in Nyasaland envisaged his training as a program for "Christian lads who will choose this work ... who will seek not only the healing of the bodies of their patients, but to lead them to the Saviour., ${ }^{, 20}$ At the General Missionary Conference of Northern Rhodesia in 1927, the prevailing view was that "the Native medical aids should be responsible male Natives ... men of good character."${ }^{, 21}$

Missionary attitudes to African men and women worked to generally exclude the latter from training programs. Missionaries expected their trainees to be Christian and they had doubts about the commitment of African women to the new faith. ${ }^{22}$ Conversely, African male trainees formed part of a select group of colonized "progressives" who were thought to have internalized a wide set of western values including literacy, reliability,

\footnotetext{
${ }^{18}$ Many early missions converts were a vulnerable population to whom the mission offered protection. It was from this population that potential early medical assistants were drawn. Curing their Ills, 61-62, Markku Hokkanen, "Missions, Nurses and Knowledge Transfer: The Case of Early Colonial Malawi," in Transnational and Historical Perspectives on Global Health, Welfare and Humanitarianism, eds. E. Fleischmann, S. Grypma, M. Marten, \& I. Okkenhaug (Kristiansand: Portal Academic, 2013), 114-115. ${ }^{19}$ As Nancy Hunt has noted, in most sub Saharan British colonies nurses were male up until the end of the Second World War. Medical work for African females was restricted to midwifery. Hunt, Colonial Lexicon, 366, fn. 56.

${ }^{20}$ Smit, 7. Emphasis mine.

${ }^{21}$ Qtd in Kumwenda, "The Training of Female Medical Auxiliaries," 101. Emphasis mine.

${ }^{22}$ Agnes Rennick, "Church And Medicine: The Role Of Medical Missionaries In Malawi 1875-1914” (PhD diss., University of Stirling, 2003), 198.
} 
deference to authority, and a Christian morality. ${ }^{23}$ Missionary doctors such as Walter Fisher at Mwinilunga in Northern Rhodesia viewed these "colonial middles" as potential "black Englishmen" and their training formed part of an extensive social engineering project across colonial Africa that sought to transform cultural, medical, and social identities. $^{24}$

In contrast, the CMML missions in the northwest province of Northern Rhodesia instigated training programs for both men and women. ${ }^{25}$ However, these were profoundly gendered in nature. African men received training in skills such as carpentry in addition to the rudiments of germ theory while the girls' education focused on learning domestic chores such as sewing and laundry and attaining midwifery and nursing skills. ${ }^{26}$ The aims of the medical training program were also gendered. Men were trained for a career offering social mobility and enhanced social status. ${ }^{27}$ Male graduates could be employed elsewhere in the colony. Those who remained within the province found that medical work often led to political power and status allowing them to acquire a substantial

${ }^{23}$ Kalusa, "Language, Medical Auxiliaries", 65.

${ }^{24}$ Ibid., 66; Hunt, A Colonial Lexicon, 114, 149-194.

25 Walima T. Kalusa, "Disease And The Remaking Of Missionary Medicine In Colonial Northwestern Zambia: A Case Study Of Mwinilunga District, 1902-1964" (Ph.D diss., John Hopkins University, 2003), 149.

26 Ibid., 152.

27 The status accorded to medical work appears to have varied across colonial Africa at different times. In the early colonial period, medical mission work was regarded as having low status in Northern Rhodesia. This supports Nancy Hunt's view of the perceived status of medical assistants in the Congo for the same period. However, in Nyasaland, the medical assistant appears to have had a much higher status. By the 1940s, the status for medical workers was uniformly higher in African colonies. Nancy Rose Hunt, "Letter-writing, Nursing men and Bicycles in the Belgian Congo: Notes Towards the Social Identity of a Colonial Category," in Paths Toward the Past, African Historical Essays in Honor of Jan Vansina, eds. Robert W. Harms et al (Atlanta, GA: African Studies Association Press, 1994), 187-189. Hokkanen, "The government medical service and British missions in colonial Malawi," 39-63. 
wealth-in-people, often establishing villages of their own. ${ }^{28}$ For women, their future role was as wives and mothers in the local villages providing western-based midwifery and infant healthcare while also teaching other women how to raise healthy children and families. ${ }^{29}$ The ulterior motive here was to dismantle the authority of the indigenous midwife often portrayed in missionary literature as the devil personified. ${ }^{30}$

\section{The Inter War Era}

In the inter war years, the colonial governments slowly started to provide more health care for their African populations. Much of this was aimed at ensuring the preservation of a productive workforce but other forces were also present. Concerns about falling populations and mission advocacy played a part. At conferences in the region, missionaries reminded the territorial governments of their responsibility to provide healthcare for all their people. The governments responded by increasing grantsin-aid to missions whereby missions received funds based on the number of beds and the amount of training they carried out. ${ }^{31}$

Increased attention to the health of colonized people in this era also owed much to post World War One discourse about the role of health and welfare in maintaining peace after the devastating loss of life during the war. The League of Nations Health Organization (LNHO) was formed principally to attend to the effects of the war on the

\footnotetext{
28 Wealth-in-people is a social system in which power, status and influence is dependent on the number of one's dependents. Kalusa, "Disease And The Remaking Of Missionary Medicine," 175.

29 Ibid., 151.

30 Vaughan, Curing Their Ills, 67.

${ }^{31}$ Michael Gelfand, Godly Medicine in Zimbabwe (Harare: Mambo Press, 1988), 75-76.
} 
health of European populations. However, in Africa it did facilitate the sharing and transfer of knowledge about tropical diseases between the colonial medical services. ${ }^{32}$

In Southern Rhodesia, the establishment of a settler government in 1923, led to healthcare policies that operated within a settler colonial framework. Having secured virtual political autonomy from Britain, the settler ruling elite followed segregationist polices designed to permanently subordinate and control the indigenous population. Chief among these was the creation of African reserves. ${ }^{33}$ In the early 1920s, an acute sensitivity to the inherent fragility of the settler state caused in part by a small white population and memories of the Chimurenga, fostered a "moral panic" in which African sexuality and pathologized, syphilitic African bodies posed an existential threat to white settlers. ${ }^{34}$ Initially, such concerns did not stimulate the building of more health infrastructure but led to legislation providing for greater surveillance and the attempted containment of "diseased" African bodies. The "moral panic" of a supposed syphilis epidemic led to the passage of the Public Health Act in 1924 that co-opted teachers, employers, and heads of families into a system of surveillance and notification. ${ }^{35}$ In addition, white Rhodesian groups such as the Rhodesian Women's League appealed to the need to protect white women and children from the syphilitic African domestic servant. ${ }^{36}$ While these interest groups called (unsuccessfully) for the construction of

32 Packard, A History of Global Health, 51-55.

33 African reserves were created in 1913 but formalized in the inter war era by the Land Appropriation Act of 1930. Brian Raftopoulos, Becoming Zimbabwe, 66.

${ }^{34}$ McCulloch, "The Management of Venereal Disease," 196. For a discussion of the "Black Peril" in Southern Rhodesia also see: Schmidt, Peasants, Traders, and Wives, 169-173.

35 McCulloch, "The Management of Venereal Disease," 204. 36 Ibid., 207. 
health clinics, their motivation was not for more treatment for Africans. The goal was to initiate a system of medical certification that would spatially control the African population and ensure that Africans in European towns and housing were free of syphilis. $^{37}$

The desire to create a buffer between a diseased African population and the European residential areas paradoxically spurred the development of rural health infrastructure in Southern Rhodesia in the 1930s. At the start of the decade, Askins, the colony's Medical Director proposed a coordinated system of health care delivery to rural Africans. Although Askins, a recently immigrated British doctor, had brought with him ideas about social medicine, he couched his arguments in terms of pathologized African bodies and European vulnerability. ${ }^{38}$ Askins argued,

"Here we have an extraordinary healthy country for white people to live in, but on the whole our death rate is not as low as it ought to be considering the young constitution of the population and as we want to have a healthy white nation we have got to tackle infectious diseases in the native. The native is the reservoir of these infectious diseases" ${ }^{39}$

37 Ibid., 206.

38 In the midst of the Depression, the concept of social medicine, based on the ideas of Rudolf Virchow amongst others, resurfaced as widespread poverty and hunger threw into sharp relief the link between economics and health. Packard, A History of Global Health, 56.

${ }^{39}$ In his study of rural healthcare in Southern Rhodesia, Glen Ncube argues, "in the context of the interwar period the idea of a district healthcare system, which was embodied in the medical units scheme, was far ahead of its time. Attempting to develop a district healthcare system among subordinate populations was even more radical." This represents an important counter to the argument that Charles Good makes that colonial authorities were not "in the business of enabling African societies to achieve better health." But perhaps as Askin's words shows it was less about improved health for the African and much more about the continued well-being of the white population and that any health benefits for the African were somewhat incidental. Qtd in Michael Gelfand, $A$ Service to the Sick (Harare: Mambo Press, 1976), 122; Ncube, "The Making of Rural Healthcare," 11; Good, The Steamer Parish, 335. 
After Askin's early death, his successor, Martin, took over the project. Martin planned the development centrifugally, moving outwards from the central plateau region, home to most of the white settler population. ${ }^{40}$ The rollout thus fit into settler colonial ideas about attending to the health of Africans in order to safeguard European health.

For many tropical colonial territories, any humanitarian impulse to provide health care in the early colonial period was limited by the desire for the colonies to be selffinancing. However, during the 1930s, a changing colonial discourse that argued for greater attention to the health and welfare of colonized subjects around the globe emerged. The discourse reflected a growing awareness among international health organizations of the need to take greater account of the social and economic determinants of health. To be sure, the shift in thinking in international health circles such as the League of Nations Health Organization and the International Health Board of the Rockefeller Foundation can be attributed to the poverty, hunger, and economic hardships of the Great Depression. But it also reflected the reality of failed disease elimination campaigns and the limited effectiveness of chemotherapy for tackling disease mortality and morbidity. As Randall Packard has shown, this changing perspective influenced the way international health organizations approached projects aimed at eradicating malaria, improving rural hygiene, and attending to malnutrition. ${ }^{41}$ In each of these, the organizations proposed solutions that embraced concepts of development. ${ }^{42}$ These included agricultural reform, better housing and sanitation, and expanded health

${ }^{40}$ Gelfand, $A$ Service to the Sick, 128.

${ }^{41}$ Packard, A History of Global Health, 60-63,

${ }^{42}$ It should be noted that these proposals faced serious headwinds from a continued belief in the ability of science to provide a solution. This limited the extent to which these progressive solutions were implemented. Ibid.,87. 
services. ${ }^{43}$ The ideology behind these proposals began to influence the way that colonial governments viewed the health of their colonial subjects. In Africa, for instance, the work of the LNHO spurred widespread research into the nutrition of African populations. ${ }^{44}$ Slowly, then, ideas emerged about the need to attend to the health of African populations and generated greater metropole funding for social services in the colonies.

The Nyasaland colonial government devoted a large proportion of this increased imperial funding to developing its health services in this period. For instance, 62 percent of monies directed at the colony for 1930 were spent on the development of healthcare facilities. ${ }^{45}$ Even so, health care remained limited and fragmented, especially for rural populations, illustrating the extent to which financing healthcare was absent in the earlier colonial era. Nyasaland was the most financially insecure of the three territories in Central Africa because it had no meaningful mineral reserves and what commercial agriculture did exist was fairly small scale. Unlike other colonies, the government remained reliant on hut tax as its main source of revenue until well into the 1930s. By 1937 the colonial government had built just ninety-three rural dispensaries. In urban areas, government hospitals existed in Zomba and Blantyre. ${ }^{46}$

The Northern Rhodesian colonial government was similarly reluctant to build any meaningful health infrastructure for Africans until the 1930s. Any facilities that were developed were in response to the need to ensure a supply of labor for the burgeoning

\footnotetext{
43 Ibid., 87.

${ }^{44}$ Ibid.,80-84. Also see Michael Worboys, "The Discovery of Colonial Nutrition,” in ed. David Arnold, Imperial Medicine and Indigenous Societies (Manchester: Manchester University Press, 1988), 208-226.

${ }_{45}^{4}$ McCracken, A History of Malawi, 261.

46 Ibid.
} 
copper mining industry. The first healthcare facilities for Africans were simple dispensaries but by the mid 1930s only fourteen of these existed along with eleven small African hospitals.

From the 1930s, the copper mining industry dominated the Northern Rhodesian economy. The industry relied on migrant labor drawn from impoverished rural areas. In contrast to South Africa, the Northern Rhodesian mining companies recognized from the outset that African migrant laborers would work more efficiently if they brought their families with them and consequently provided wives and children with rations and gave married men slightly better housing. ${ }^{47}$ Conditions were still dire. The Roan Antelope Mine in Luanshya, was known as "Death Valley." ${ }^{48}$ High rates of mortality and morbidity persisted through much of the inter war era due to malaria, pneumonia, influenza, and fecal-borne diseases. ${ }^{49}$ In addition, the mine management failed to build hospital facilities for Africans. ${ }^{50}$ The widespread Northern Rhodesian copper mine strikes of 1935 were, in part, a protest at these conditions. ${ }^{51}$

Concerned by the economic impact of malaria on production, the mining companies initiated a program of integrated malaria control that would continue until 1960. The program used a mixture of environmental control, sanitation and housing

${ }^{47}$ Roberts, A History of Zambia, 188. This was in contrast to the policy in South Africa where migrant labor was overwhelmingly composed of single men. Randall M. Packard, "Tuberculosis and the Development of Industrial Health Policies on the Witwatersrand, 1902-1932," Journal of Southern African Studies 13, Special Issue on The Political Economy of Health in Southern Africa (1987): 187-209.

${ }^{48}$ Walima T. Kalusa, "Aspects of Health in the Mining Industry in Colonial Zambia: A Case Study of the Roan Antelope Mine, 1920-1964 (master's thesis, University of Zambia, 1993), 22.

${ }^{49} \mathrm{Ibid}$.

50 Ibid., 23.

${ }^{51}$ Roberts, A History of Zambia, 202. 
improvements, and diagnosis and treatment in addition to surveillance and monitoring. ${ }^{52}$ As part of the program, medical facilities for Africans were somewhat improved and by the start of federation the mining companies operated four African hospitals. ${ }^{53}$ However, government facilities on the Copperbelt remained sparse even as the urban population increased when demand for copper drove higher levels of production. ${ }^{54}$

The need for African labor for the mining industry also shaped health care policies in rural areas in Northern Rhodesia. Concerns about what appeared to be a precipitous drop in the African population in the south of the colony and the need to ensure labor supplies shaped responses to what the colonial authorities believed to be a long lasting epidemic of syphilis. ${ }^{55}$ The responses of the government medical services reflected the waxing and waning labor demands of the copper mines. The rapid expansion of the copper industry in the late 1930s and beyond created the context for vigorous rural treatment campaigns. In addition, the campaign against syphilis in the southern province became the model for other interventions elsewhere in the colony. ${ }^{56}$

The perceived need for more rural health infrastructure in the 1930 s convinced the Directors of Medical Services of all three colonies to begin training African medical personnel. In common with the missionary driven gendered construction of the medical

52 For a fuller description of the methods used see: Malcolm Watson, African Highway: The Battle for Health in Central Africa (John Murray: London, 1953). For an evaluation of the economic impact of the program see: J. Utzinger, Y. Tozan, F. Doumani, and B. H. Singer, "The economic payoffs of integrated malaria control in the Zambian Copperbelt between 1930 and 1950, Tropical Medicine \& International Health, 7 (2002), 657-677. 53 The Federation of Rhodesia and Nyasaland, Annual Reports on Public Health, 1955 (BOA), 15.

54 Roberts, A History of Zambia, 204.

55 Bryan Callahan, “Veni, VD, Vici'?: Reassessing the Ila Syphilis Epidemic,” Journal of Southern African Studies 23, 3 (1997), 421-40.

56 Ibid. 
assistant, governments envisaged that training would be for men only, except for midwifery. The Northern Rhodesian colonial medical department asserted that " the native female of this territory is at present inherently unsuited to such [medical] work and ... she should be ... altogether disregarded in this connection. ${ }^{.57}$ Given the dominance of the female nurse in western thought, it is noteworthy that this was one western practice that Europeans did not initially, at least, attempt to map onto the tropical African context.

Western nursing ideology that framed nursing as inherently feminine work did not sit well within missionary and colonial discourse that viewed the African female's role as reproducer of the male colonized labor force. Nursing can be considered reproductive work, in the sense of healing bodies. If, instead, we view nurses as economic actors and the work that they do as productive, it is possible to see why female African nursing could be considered problematic within the colonial context. ${ }^{58}$ Medical work could represent significant opportunities for capital accumulation even if female nursing orderlies and midwives did not earn as much as male hospital assistants. ${ }^{59}$ In addition, nursing work would take women out of the home. An ideology of domestication created an ideal African woman whose place was within the confines of a rural village, a construction with which African elders collaborated in order to bolster elder, male

${ }^{57}$ Qtd in Kumwenda, "The Training of Female Medical Auxiliaries," 101. Emphasis mine.

${ }^{58}$ I am following Luise White's framework of prostitution in colonial Nairobi being reproductive in the sense of reproducing the migrant male labor by offering them "the comforts of home" but also as productive work in the way that it allowed women to accumulate capital and establish independent households. Luise White, Comforts of Home: Prostitution in Colonial Nairobi (Chicago: University of Chicago Press, 1990). ${ }^{59}$ Markku Hokannen argues that male hospital assistants in Nyasaland were some of the highest paid Africans in the colony by the 1920s and contributed to the demise of the medical assistant programs at the missions as nurses came to be seen as a cheaper option. Hokkanen, "Missions, Nurses,” 29. 
authority. The maintenance of the power and authority of chiefs, elders, and headmen was crucial to the success of indirect rule and thus to the entire colonial project.

Successful colonial rule required the assistance of African male authority to collect taxes, enforce labor policies and maintain the colonial social order. The ability of women to achieve greater independence through paid work risked disrupting this chiefly power and therefore alienating the African allies that colonial rule relied on. Access to medical training offered opportunities for African women that risked upsetting this delicate balance. Colonial authorities generally put long-term political objectives before other concerns. ${ }^{60}$ In the case of medical training, it would appear that the governments were prepared to deny the utility of African female medical staff in order to maintain the colonial social order.

Gendered ideology about access to education also served to persuade government health officials to initially only provide medical training for men. Government neglect of education for Africans meant that prior to the Second World War, the primary way for Africans to be educated was at mission schools. ${ }^{61}$ Missionary ideas about education made it more likely that recipients of mission education were males. In addition, even where females had access, the gendered education curriculum at mission schools meant that it was men who generally had the literacy and English language skills required for

60 Schmidt, Peasants, Traders, and Wives, 121, 157.

61 Carol Summers, Colonial Lessons: Africans' Education in Southern Rhodesia, 19181940 (Portsmouth, NH: Heinemann, 2002). Sybille Küster, Neither Cultural Imperialism nor Precious Gift of Civilization: African Education in Colonial Zimbabwe 1890-1962 (Studien Zur Afrikanischen Geschichte; Bd. 8. Münster: Lit, 1994). 
acceptance into a training program. ${ }^{62}$ In Nyasaland, the Scottish missions training programs for medical assistants required a candidate to have completed at least three or four years of academic schooling in order to be considered ${ }^{63}$ In Southern Rhodesia, the government demanded that trainees in mission hospitals had to have attained at least a standard IV education and were literate in English if the mission wanted to continue receiving grants-in-aid from the government. ${ }^{64}$

The one area of training that was available to women from relatively early on was midwifery. While training for midwives was certainly not available in Central Africa as early as it was in Uganda or Kenya, the CMML program in Northern Rhodesia was underway by the 1930s. Midwifery was also taught at the LMS mission at Mbereshi, also in Northern Rhodesia. This program was supposedly designed to supply trained assistant nurses for use in the wider government medical service. The program's adherence to the missionary educational ideology of domesticity reduced its efficacy, and it later lost its government funding amid criticism that it had not delivered on its promises to provide assistant nurses for the colony. ${ }^{65}$

${ }^{62}$ The mission schools' education curriculum for boys was designed to allow them to interact with the colonial state. As such, boys received English language instruction, literacy skills, and training for trades such as driving and carpentry. Conversely, a typical curriculum for girls was based on teaching domestic skills such as cooking, sewing, and doing laundry. Girls were to be actively discouraged from academic work although if parents agreed to pay extra fees, some basic literacy training would be provided. African girls were much less likely to receive any English language instruction because it was not seen as a priority among mission educators. Schmidt, Peasants Traders and Wives, 131132.

${ }^{63}$ Smit, "The Training of African Nurses," 5.

${ }^{64}$ Government Notice 335, 1927, qtd in Gelfand, A Service to the Sick, 116-117.

${ }^{65}$ Kumwenda, "The Training of Female Medical Auxiliaries," 111-114. 
Government training schools opened in all three colonies in the late 1930s. Each aimed to provide male medical auxiliaries who would work in rural health care facilities. In Southern Rhodesia, schools in Bulawayo and Salisbury trained male nursing orderlies from 1937. The course provided breadth rather than depth of knowledge. Trained orderlies were equipped to treat minor ailments and recognize more serious conditions for referral. It seems that the government struggled to train sufficient numbers. Each rural clinic was supposed to be staffed by two or three orderlies. The African staff was to have a great deal of autonomy because a medical doctor only visited the clinics on a weekly or fortnightly basis. By 1944, although there were sixty-six clinics, only sixty orderlies were listed on the nursing orderly register. ${ }^{66}$

In Nyasaland, proposed government training programs aimed to produce male auxiliaries who could act as dresser-dispensers. They were taught diagnostic and therapeutic techniques that enabled them to treat many of the minor cases at rural dispensaries and clinics. Crucially, the program also sought to "produce men with a knowledge of hygiene and sanitation applicable to village life, so that they may play their part as advisors to native authorities. ${ }^{, 67}$ Rural medical assistants were seen to have a dual role, curative and preventative, but this comment also seems to suggest that medical assistants would return to their villages with a social status enhanced by the accumulation of biomedical knowledge. It should be noted that while the government school trained male medical aides, the missions continued to train male hospital assistants. Hospital

66 Gelfand, A Service to the Sick, 138-141.

${ }^{67}$ Nyasaland, Report on Public Health, 1936 (BOA), 35.Emphasis mine. 
assistants had significantly more training and also enjoyed a much higher status. ${ }^{68}$ Hospital assistants trained at the Blantyre mission had comparable skills to the medical assistants who had been trained in Uganda since $1927 .{ }^{69}$ On graduation, hospital assistants were placed on the same register as sub-assistant surgeons, a classification used for non-European doctors. ${ }^{70}$

The emphasis on producing medical assistants for rural health work is a persistent thread in the sources. The rationale behind this is twofold. First, the understanding was that it was impossible to staff rural clinics and dispensaries with professionally qualified doctors and state registered nurses. While Southern Rhodesia established a state registered nursing program in the early years of the colony, this was entirely the preserve of European women. In addition there was no medical school. Thus all three territories were reliant on expatriate staff. This reliance tended to lead to shortages in staff and meant that rural areas were often at the end of the line when it came to deploying expatriate biomedical expertise. This was one reason why the contribution of missionary medicine to the provision of health care was so important throughout the colonial period. It was often the missionary doctors and nurses who were prepared to work and live in remote areas. The second rationale was that any moral impulse driving colonial medical authorities to provide more extensive health care was fiscally constrained by the overall colonial economy. ${ }^{71}$ Dr Mackenzie, director of medical services, explained that

${ }^{68}$ Austin C. Mkandawire, Living My Destiny, A Medical and Historical Narrative (Glasgow: Dudu Nsomba Publications, 1988), 84.

${ }^{69}$ John Iliffe, East African Doctors, 62-63.

${ }^{70}$ Mkandawire, Living My Destiny, 85.

${ }^{71}$ The fiscal constraints were exacerbated by an imperial policy mandating colonies should be self-sufficient. This persisted until around 1940 from which time European 
Nyasaland, a colony dependent on a subsistence agricultural economy, needed a health service commensurate with its ability to fund it. In his opinion this meant Nyasaland needed a service consisting, for the most part, of a "cadre of African auxiliaries to staff a health service able to provide treatment $\ldots$ at a cost the country could afford." ${ }^{, 72}$

By 1940, government training schools for men operated in all three colonies. While Northern Rhodesia and Nyasaland concentrated their efforts on training staff for curative services, Southern Rhodesia also initiated a program for training hygiene demonstrators whose work encompassed a broad spectrum of preventative services such as health education, water treatment, and housing improvements and would later form a follow-up service in the efforts to control tuberculosis. ${ }^{73}$

\section{Towards the Post War Era}

The 1935 strike on the Northern Rhodesian Copperbelt was an early manifestation of an empire-wide series of strikes, demonstrations and riots that erupted between the mid 1930s and $1950 .{ }^{74}$ The strikes expressed African demand for more equitable labor policies and social services. ${ }^{75}$ The British government determined that a program of economic development was needed. The program aimed to stimulate the building of

powers recognized that if they were fully exploit the economic potential of their colonies, they would need to invest more comprehensively in areas such as health and education. Packard, A History of Global Health, 93.

72 The Federation of Rhodesia and Nyasaland, Annual Reports on Public Health, 1954 (BOA), 20.

${ }^{73}$ Gelfand, A Proud Record, 30.

${ }^{74}$ Frederick Cooper, Africa since 1940, 30.

${ }^{75}$ Cooper warns that viewing the workers' activism of the 1930s and 1940s as inevitably part of nationalistic politics ignores the very diverse local conditions and grievances of striking workers. Ibid., 20. 
infrastructure to improve the standard of living of colonial subjects. In 1940 the British parliament passed the Colonial Development and Welfare Act. ${ }^{76}$ In Northern Rhodesia and Nyasaland, this development ethos spurred the production of ten-year plans, which included provision for increased medical facilities. However, by the start of federation, little progress had been made and they subsequently became the basis for infrastructure development in the federal period.

During and immediately after the Second World War rapid development of a manufacturing sector transformed the Southern Rhodesian economy. ${ }^{77}$ Simultaneously, there was a shift in ideas about the role of the African population within the colonial state. ${ }^{78}$ This reflected the reality of a rapidly expanding urban African population.

Africans provided the necessary labor for the increasing industrialization and they were also important potential consumers of manufactured goods. In 1944, the Southern Rhodesian Prime Minister, Godfrey Huggins argued that a universal health service was vital for the future wealth and development of the colony in the aftermath of the Second World War. ${ }^{79}$ Huggins emphasized, "there can be no more important object than the

\footnotetext{
76 Ibid., 31.

77 By 1951, three times as many Europeans worked in the manufacturing sector as did in farming. John Richard Gray, The Two Nations Aspects of the Development of Race Relations in the Rhodesias and Nyasaland (London: Oxford University Press, 1960), 204.

${ }^{78}$ Part of paradox of settler colonialism in Africa is that white settlers wanted to banish Africans to native areas even as they recognized their importance in the colonial economy.

${ }^{79}$ It should be noted that a similar discourse about the desirability of a national health service emerged in the 1940s in South Africa, leading to a National Health Service Commission in 1944, see: Shula Marks and Neil Andersson, "Industrialization, Rural Health, and the 1944 National Health Services Commission in South Africa," in The Social Basis of Health and Healing In Africa, eds. Steven Feierman and John M. Janzen (Berkeley: University of California Press, 1992), 131-161.
} 
attainment of health and the prevention of disease. It is an ideal that we must place first in our plans for reconstruction. ${ }^{.80}$ Huggins further stressed that the provision of health services was foundational to the building of the state saying, "all our plans for increased production and wealth will be to no avail unless we have a fit and healthy population to produce wealth and enjoy it when it is produced. ${ }^{\prime 81}$ The building of the colonial state thus became intertwined with the need to pay more attention to the welfare of the indigenous population.

Despite rhetoric about the need for a national health service, by 1945, health care provision in Southern Rhodesia remained segregated and unequal. While the European population enjoyed a fairly comprehensive health system, provision for African health care was rudimentary. For example, while the number of rural health clinics rose from 31 in 1935 to 67 ten years later, the number of Africans attending clinics as out-patients increased by a factor of 10 , from around 22,000 in 1935 to more that 203,000 a decade later. In contrast, all the major settlements had general hospitals for Europeans providing sufficient beds, as well as radiographic and laboratory facilities. ${ }^{82}$ The government had built some hospitals for Africans in the major towns in the earlier colonial period but by the post war era, they were hopelessly inadequate for the task. ${ }^{83}$ African hospitals often operated at 135 percent of capacity. ${ }^{84}$ Medical commentators placed the blame for this

${ }^{80}$ Godfrey Huggins, "National Health Service, Prime Minister's Survey of Conditions in S. Rhodesia," Address to Public Meeting at Bulawayo, Feb 1, 1944, AD1715, Hospitals Beyond South Africa, 9.12.1.4 SAIRR, 1.

${ }^{81}$ Godfrey Huggins, "National Health Service," 1.

${ }^{82}$ Southern Rhodesia, Report on Public Health, 1945 (BOA), 3.

${ }^{83}$ It should be noted that Africans attending urban hospitals were expected to pay for their care in the early years of the colony unless they could prove they were indigent. ${ }^{84}$ Gelfand, A Proud Record, 16. 
exponential increase in the numbers of Africans seeking treatment rather than any deficiency of investment on the part of the government. ${ }^{85}$ It seems that medical discourse lamented the persistence of "native practices" and the innate superstitions of Africans for the slow acceptance of biomedicine in the early colonial period only to complain that Africans were overwhelming the facilities later on. The increase in numbers is undeniable with admissions to African hospitals doubling between 1944 and $1949 .{ }^{86}$

After 1940, ideas about the male identity of nurses in tropical Africa underwent a revision. In part, the shift reflected the wartime demand for male medical auxiliaries to work in military hospitals resulting in staff shortages in civilian hospitals and clinics. The change also occurred because ideas about nursing as women's work became increasingly dominant in the colonial setting. ${ }^{87}$ This perspective suggested that the inherently female aptitude for nursing would improve standards of care in hospitals. Thus colonial governments put greater emphasis on training female African nursing assistants. In this endeavor, missions were seen as the most suitable sites for nurse training because it was thought missionaries could better safeguard students' moral virtue. ${ }^{88}$ However, increased numbers of African girls completing the requisite amount of education also led the colonial authorities to start government training of female nursing auxiliaries in all three territories by 1950 .

On the eve of federation, the colonial governments, missions, and mining companies across the region carried out training of male and female auxiliaries including

\footnotetext{
85 Ibid., 16-17.

86 Southern Rhodesia, Report on Public Health, 1944-1949 (BOA).

${ }^{87}$ Kumwenda, "The Training of Female Medical Auxiliaries," 101 ${ }^{88}$ Ibid.,117.
} 
medical assistants, midwives, laboratory assistants, and health assistants. However, training remained fragmented within each territory and reflected the needs of the individual colonies. Missions generally followed their own programs and either sent their pupils to government schools for a period of time towards the end of training or asked the government services to examine the pupils when training had been completed. These steps were taken to ensure that trained mission staff would be employable within a government service. The government-operated programs differed considerably. The programs in Nyasaland were longer and certainly more rigorous than that in Northern Rhodesia. In addition, the auxiliary training reflected the different roles that medical assistants played in health service provision in the three territories. In Southern Rhodesia, nursing orderlies followed a curriculum predicated on care-giving while in the Northern territories greater attention was given to the teaching of diagnostic practices because it was recognized that medical assistants had to be able to work in rural settings for long periods with only minimal supervision. ${ }^{89}$

Significantly, there were no facilities for providing advanced medical training for Africans in the region. While calls for training African state registered nurses dated back to the early 1940s in Southern Rhodesia, professional nursing remained the preserve of white women until well into the federal period. This is in contrast to South Africa, which had around 800 black registered nurses by $1948 .{ }^{90}$ Furthermore, unlike South Africa and

89 This point is made in the 1955 report where it says that training had evolved in each territory to meet "local problems." The Federation of Rhodesia and Nyasaland, Annual Reports on Public Health, 1955 (BOA), 27-28.

90 Shula Marks, "The Legacy of the History of Nursing for Post-Apartheid South Africa," in Nursing History and the Politics of Welfare, eds. Ann Marie Rafferty, Jane Robinson and Ruth Elkin (London: Routledge, 1997), 33. 
colonies such as Uganda and Nigeria, there was no medical school in which to train doctors. The nearest equivalent was the hospital assistant course at the Blantyre mission in Nyasaland. The Nyasaland government opened its own school for hospital assistants in Zomba in the 1940s but trained very few students. Austin Mkandawire, a hospital assistant in Nyasaland in the 1950s, was one of just four men selected for the training program after successfully completing the medical aides course.${ }^{91}$ The lack of advanced training facilities had the effect of concentrating professional biomedical expertise in Europeans. In addition, policies that required white nurses to resign on marriage created a chronic shortage of professional nurses that persisted into the federal era. Reliance on European doctors meant competing within a global marketplace for an increasingly scarce resource.

The colonial governments of Central Africa paid greater attention to health care for their African populations in the decade prior to the creation of the Federation. Some infrastructure was added. Even so, the services were insufficient to meet rising demand. Furthermore, staff shortages had become a chronic problem. The lack of any professional medical training programs perpetuated a reliance on expatriate doctors and professional nurses, staff that was increasingly difficult to recruit. The gendered colonial attitude toward auxiliary training and neglect of African education limited the numbers of nursing orderlies, medical aides, and other medical workers that could be trained. As a result, governments struggled to adequately staff their hospitals and clinics, even as

${ }^{91}$ Mkandawire, Living My Destiny, 105. 
infrastructure was added. It was on these shaky foundations of health that the Federal Health Service attempted to build. 


\section{Chapter Two.}

\section{Federating Health}

The Central African Federation was a co-production of Britain and the leaders of white settlers in Central Africa. The Federation owed its existence to the alignment of British and white settler interests. Africans, for their part, feared the potential loss of land and the prospect of white domination. In this chapter I examine how health came to be a federal function and argue that the story of how the Federation came into being and the process of federating health is best understood as part of white settler nation building. The importance of health to the settlers' national project is indicative of the perceived links between health and development that emerged in the early 1940s. At the same time, federating health affected the working conditions of the hundreds of employees of the colonial government services. The manner in which this was carried out would have implications for the health service throughout the federal decade.

\section{Closer Union in Central Africa}

The Central African Federation has been described as a "large-scale imperial exercise in constructive state-building." "Proposals for greater inter-territorial planning and coordination in areas of British controlled Africa emerged in the immediate post World War One era. They gained greater currency in the aftermath of the Second World

\footnotetext{
${ }^{1}$ Ronald Hyam's main argument is that that the Federation was created as a buffer to fears of South African expansion. Ronald Hyam, "The Geopolitical Origins Of The Central African Federation: Britain, Rhodesia And South Africa, 1948-1953," The Historical Journal, 30, 1 (Mar., 1987), 145.
} 
War when federation appeared to offer a means of improving government regulation and coordination of colonies within a wider geographical region such as East Africa. ${ }^{2}$

However, the Central African Federation also owed its existence to the determination on the part of white settlers of Southern and Northern Rhodesia. Many of these had long envisaged the creation of a white state in Central Africa. ${ }^{3}$

The first stirrings of a political union between the colonies can be traced to an attempt in 1916, by the BSAC to amalgamate the two Rhodesias. ${ }^{4}$ The move invoked a backlash from white settlers in Southern Rhodesia who were agitating for an end to company rule and wanted to get responsible government. In the 1930s, the tiny white settler population in Northern Rhodesia began to expand in the wake of the discovery of vast deposits of copper near the Katangan border with the Congo. At the same time, a commission from Britain reported that some form of closer union was possible as long as the concept of native paramountcy, the protection of African interests over those of nonAfricans, was upheld. ${ }^{5}$ The report spurred a surge of settler nationalism within those Northern Rhodesian whites who looked enviously to the south where the interests of the white population were always privileged over those of Africans. The rapid wartime expansion of the copper mining industry brought increasing numbers of white settlers

\footnotetext{
${ }^{2}$ Kenneth C. Omeje and Tricia M. Redeker Hepner, Conflict and Peacebuilding in the African Great Lakes Region (Bloomington, Ind: Indiana University Press. 2013), 51. ${ }^{3}$ I am following Phillip Murphy revision of Hyam's argument that support for Federation was in large part due to British fears of South African political encroachment. Murphy gives greater credence to settler nationalism. Philip Murphy, "'Government By Blackmail': The Origins of the Central African Federation Reconsidered in The British Empire in the 1950s: Retreat or Revival, ed. Martin Lynn (London: Palgrave Macmillan, 2006), 53-76.

${ }^{4}$ West, 180.

${ }^{5}$ Ibid., 181.
} 
onto the Copperbelt, many of them Afrikaners from South Africa. In 1945, the politician and leader of the small but growing white settler population in Northern Rhodesia, Roy Welensky, linked the defense of the British Empire to calls for a white dominion in Central Africa. ${ }^{6}$ He also argued that administration by the colonial office impeded the development necessary to improve the colony's standard of living. Welensky pointed to Southern Rhodesia's rapid development of manufacturing and expansion of health services as evidence of the benefit of a self-governing colony. ${ }^{7} \mathrm{He}$ argued that the Southern Rhodesia trained nurses, paid higher wages, and had expanded medical education. He conveniently ignored that the number of nurses trained by the Southern Rhodesian service was tiny because state registered nurse training was limited to white women only, that it struggled to retain the services of the nurses and doctors it employed, and that the state had only trained (male) African nursing orderlies since 1937. From the start, then, the idea of closer association and the creation of a white nation and the part that health played in this were intricately linked. Amalgamation was a way to ensure European domination of political and civil institutions in the region.

Prior to the Second World War, The British government had been opposed to any initiatives to bring together the Rhodesias due to differences in policies towards Africans. ${ }^{8}$ The 1940 s marked a change in attitude to one favoring, at least in principle, some form of political union. This was, in part, fueled by concerns of a northward creep of the Afrikaner apartheid worldview. British fears about Afrikaner expansionism

\footnotetext{
6 Wood, Welensky Papers, 88.

7 Ibid., 97.

8 The 1937 Bledisloe Commission had reported that different approaches to African affairs precluded any possibility of a closer political union. Wood, Welensky Papers, 6465.
} 
gathered pace in the wake of the Nationalist Party victory in the South African elections in 1948. As important, though, was the fear that increased nationalist activity could lead to a violent settler revolt on the Copperbelt. ${ }^{9}$ The perceived solution was the creation, in 1945, of the Central African Council, designed to foster closer ties between the colonies. For the British government, the hope was that the council would deflect ideas about amalgamation. To Welensky and the Southern Rhodesian premier, Godfrey Huggins, it represented a stepping-stone towards the desired political union. ${ }^{10}$

At the same time, the idea of amalgamation was bound up with the economic interests of the white settlers in both colonies. The Northern Rhodesians pressed for the nationalization of the copper mining industry while Southern Rhodesians wanted the same for the railway system. To that end, the Southern Rhodesian government secured funding to take over Rhodesia Railways. The consequent loan commitments increased Southern Rhodesian desire for amalgamation in order to access the lucrative revenue from copper. ${ }^{11}$ Economically, then, Southern and Northern Rhodesian settlers took steps to secure control over the region's resources, an important step in nation building.

Although the British government was more amenable to the idea of some sort of closer union during the 1940s, the ruling Labour Party remained firmly against amalgamation. This led the settler leaders' Welensky and Huggins to turn to federation as a possible, viable alternative means of achieving the same ends. As Philip Murphy has argued, Welensky was prepared to resort to a policy of non-cooperation to force Britain to shift its stance towards acceptance of federation. Welensky played on the British

\footnotetext{
9 Murphy, “'Government By Blackmail'," 55.

10 Ibid., 55.

11 Ibid., 57-58.
} 
geopolitical concerns pointing to the potential for Afrikaners to be dominant in the Northern Rhodesian legislature after the general election, due in $1949-50 .{ }^{12}$

The turning point was the change in government in Britain in 1951. The Conservative party victory meant that for the first time, the interests of the British government and Rhodesian settlers aligned in support of federation. As John McCracken notes, reasons for the inclusion of Nyasaland have not been adequately explained. Arguments that Southern Rhodesia agreed to include the colony in order to secure access to Nyasaland labor are unconvincing. ${ }^{13}$ The long history of Nyasaland as a labor reserve illustrates that access was not dependent on a political union. Migrant labor from the colony had been important to Southern Rhodesian farms and mines since the early part of the century. ${ }^{14}$ Nyasaland's inclusion was also unwelcome to the Nyasaland governor. Colby actively campaigned against Nyasaland's involvement, warning that federation was likely to foster African unrest. The British government ignored Colby's appeal, perhaps providing the basis for speculation in the historiography that British officials saw federation as an opportunity to divest Britain from some of its financial responsibilities towards the colony. ${ }^{15}$ It should also be noted that Nyasaland was one of a number of financially constrained colonies that the Colonial Office believed could only become

\footnotetext{
12 Ibid., 60-61.

${ }^{13}$ McCracken, A History of Malawi, 277.

${ }^{14}$ In the field of health, too, migrant labor from Nyasaland was important as medical auxiliaries trained in the colony were in demand in both Southern Rhodesia and Northern Rhodesia. Gelfand, A Service to the Sick, 139. 15 McCracken, A History of Malawi, 276-277.
} 
viable nation-states as part of a wider geographical political community. ${ }^{16}$ There is also some evidence that Britain insisted on the inclusion of Nyasaland in order to give the project the illusion that Federation was not a form of surrender to settler nation building. ${ }^{17}$

African resistance to any sort of closer union, amalgamation or federation was widespread and profound. Southern Rhodesian Africans viewed political union as an impediment to Africans' desire for self-determination. ${ }^{18}$ They also feared that it would led to a more independent settler colony and threaten Britain's existing veto power over any Southern Rhodesian parliamentary legislation that affected African interests. ${ }^{19}$

In Northern Rhodesia and Nyasaland, Africans feared the expansion of the white settler state and the specter of white domination. In both colonies, antipathy to a closer union was intricately bound up with the land. In Nyasaland, resistance to federation was tightly linked to colonial development plans. Coercive soil conservation projects such as ridging were viewed as a threat to land security. The imposition of federation raised a similar fear as Africans worried about Rhodesian land alienation policies and a potential influx of settlers. ${ }^{20}$ The links between conservation measures and mass anti-Federation sentiment were aptly expressed by a women's song sung in 1953:

Federation capitaos

$\mathrm{e}-\mathrm{e}-\mathrm{e}$

Sooner or later you will die

${ }^{16}$ McCracken says that this view was widespread in the Colonial Office in the early 1950s. Other colonies included Sierra Leone, the Gambia, and individual West Indian Islands. Ibid, 277.

${ }^{17}$ Murphy, “'Government By Blackmail'," 72.

18 West, Rise of the Middle Class, 190.

${ }^{19}$ Ibid., 181.

${ }^{20}$ McCracken, A History of Malawi, 322. 
$\mathrm{e}-\mathrm{e}-\mathrm{e}$

Contour ridging capitaos

$\mathrm{e}-\mathrm{e}-\mathrm{e}$

Sooner or later you will die

$\mathrm{e}-\mathrm{e}-\mathrm{e}$

You will die but you don't know it. ${ }^{21}$

The song articulates the notion that from an African perspective, federation posed an existential threat. Africans listened when Welensky said, "If they [Africans] do not come with us, ... they will meet with the same fate that came to the Indians in the USA. They

disappeared." 22 Examining the trepidation with which Africans viewed federation helps explain future reluctance to federal employment and resistance to public health campaigns in Northern Rhodesia and Nyasaland during the federal era.

\section{Federating Health}

It was not immediately obvious to many involved in the conferences leading to the creation of the Federation that health should become a federal function. At the Victoria Falls conference in 1949, for example, a subcommittee convened to consider the handling of social services under any such federal outcome, recommended that while hospitals would be better placed under federal control, clinics and dispensaries, the nuts and bolts of rural healthcare, should remain the responsibility of the territorial governments. ${ }^{23}$ At each of the ensuing conferences, health proved to be a contentious issue. Even as delegates acknowledged the benefits that could accrue from a unified health service, politically it was divisive. At the Officials Conference in London in March

\footnotetext{
${ }^{21}$ Qtd in McCracken, 321, emphasis in the original.

22 Qtd in Peter Fraenkel, No Fixed Abode: A Jewish Odyssey to Freedom in Africa (London: I.B.Tauris, 2005), 219.

${ }^{23}$ Wood, The Welensky Papers, 140.
} 
1951, the Southern Rhodesian contingent became frustrated when the Nyasaland and Northern Rhodesian delegations declared that health must remain a territorial concern. The northern delegates pointed out that the territories had existing development plans that could be difficult to combine and that funding had already been earmarked for expansion of health services. In addition, they argued that rural health provision was enmeshed with local district administration. Further, they claimed that health was such an integral part of everyday life of the African that unification risked alienating support for the entire federal project. Lastly, they asserted that any proposal for unification of the territorial health services should not be considered at least until the territorial medical directors had been consulted. ${ }^{24}$ For their part, the Southern Rhodesians believed that Africans would not see any change in service and therefore would have no objection. At this juncture in the conference, health became a metaphor for what the Southern Rhodesians viewed as "the negative and destructive criticism" which countered any proposed mergers of services put forward by the southern colony. In their opinion the delegates from the northern territories were using well-known African resistance to federation to place obstacles in the way of a "free discussion of every problem. ${ }^{, 25}$ In the end the conference report tried to reconcile the interests of both camps. It recommended that health should remain a territorial concern while also suggesting that some specialist services (to be determined) could come under federal control. ${ }^{26}$

\footnotetext{
24 Ibid., 178.

25 Ibid., 178-179.

26 TNA CO 129/45/CP (51) I 22: Annex II, "Report of Conference on Closer Association in Central Africa,” March 1951, 16, 20, 39.
} 
In March of 1952, the Southern Rhodesians made another concerted effort to appropriate health for the federal government. The meeting, held in Lusaka in Northern Rhodesia, was one of a series held prior to an upcoming conference on federation in London. In addition to health, meetings were held to discuss the viability of federating the police and prison service as well as agriculture and marketing. No representatives from either the Colonial Office or the Commonwealth Relations Office attended.

Colonial officers in London would later express surprise that the meeting had taken place at all as it was thought that the decision to make health a territorial matter had already been finalized. ${ }^{27}$ African representation was also conspicuously absent. The meeting brought together the most senior health officials of the three colonies, a member of the Central African Council, the Southern Rhodesian minister for health, and the member for health in the Northern Rhodesian legislative council. ${ }^{28}$

The archival record illustrates the forcefulness with which the Southern Rhodesian delegates approached this meeting. It is obvious that they arrived in Lusaka intent on securing agreement for the unification of health services. While the ultimate decision would be taken at the London conference in the April, it appears the Southern Rhodesians wanted to be able to leave the meeting with a firm recommendation that the rationale for unification on technical and professional grounds outweighed any political consideration. The Southern Rhodesian medical director, Morris, was arguably the strongest advocate for this position. Morris had been part of a medical sub-committee set

27 TNA CO 1015/634: J.W. Stacpoole, circulation notes on the Record of a Meeting on the Unification of the Health Services in Southern Rhodesia, Northern Rhodesia, and Nyasaland.

${ }^{28}$ TNA CO 1015/634: "Record of a Meeting on the Unification of the Health Services in Southern Rhodesia, Northern Rhodesia, and Nyasaland," 2. 
up under the Central African Council prior to federation. ${ }^{29}$ The committee had been formed with the intention of coordinating the health work of the three colonies.

According to Morris, it utterly failed to achieve its purpose. ${ }^{30}$ Morris would later say:

"There were those of us who endured the occasional but over-prolonged sittings of the medical sub-committee set up under the Central African Council, with the duty of co-ordinating the health work of the three territories. This subcommittee achieved nothing. It failed even to provide a channel whereby information on "major public health schemes" could be exchanged." 31

At the Lusaka meeting, Morris argued that the examples of the Union of South Africa and Australia, where the provision of health had been divided between federal and state departments had not "proved very happy in their results." ${ }^{32}$ Morris believed that any such move would be "wasteful of both manpower and finance and lead to friction between the directors of medical services and to frustration on the part of the officer called upon to administer the federal rump. ${ }^{, 33}$

For his part, the Southern Rhodesian Minister for Health, Fletcher, minimized any differences of opinion amongst the participants. Morris and the Northern Rhodesian Director of Medical Services, Robinson, differed over the extent to which federalizing health presented increased opportunities for professional advancement. Morris said that the larger federal service offered better prospects than the smaller individual territorial

${ }^{29}$ The Central African Council (CNC) was composed of a number of sub-committees designed to facilitate cooperation between the colonies in areas such as labor recruitment, inter colonial trade etc. TNA DO 35/1161: Andrew Cohen, "Central African Council," Minute, February 28, 1945.

${ }^{30}$ R.M. Morris, "Health and the Monckton Commission Report," CAJM, 6,11 (1960), 497.

${ }^{31}$ Ibid.

32 TNA CO 1015/634: "Record," 2.

${ }^{33}$ R.M. Morris, "Health and the Monckton Commission Report," CAJM, 6,11 (1960), 498. 
services. Robinson, however, argued any such advantage would only be realized by the Southern Rhodesian European staff because, in contrast, the staff of the northern territories stood to loose their connections to the global professional network of the colonial medical service. Fletcher brushed off Robinson's objections and quickly moved on to emphasize the benefits and practicability of unification. ${ }^{34}$

The Southern Rhodesian delegates argued that one of the major benefits of unifying health would be the standardization and expansion of medical training. The broader base of training would provide more curative staff capacity but also more staff to work in preventative medicine enhancing the dissemination of health education and hygiene practices. ${ }^{35}$ The meeting threw into sharp relief the regional differences in the services' ability to fill their respective training programs each year. While those in Southern Rhodesia and Nyasaland received twenty applicants for each available place, the delegates from Northern Rhodesia admitted to persistent shortages in suitable candidates. ${ }^{36}$ In addition, the Southern Rhodesian contingent argued that federal control of health would allow the more rapid expansion of advanced training because it was probable that the federal government would attract more investment and because of greater efficiencies in a unified service. ${ }^{37}$ Furthermore, they asserted that merging the health services would allow the health ministry to regulate medical training so that numbers trained could be better matched to demand across the Federation. ${ }^{38}$

\footnotetext{
34 TNA CO 1015/634: "Record," 2.

35 Ibid., 8.

36 Ibid.

37 Ibid.

38 The only dissenter was Dr Mackenzie, the director of the Nyasaland Medical Service who strongly asserted that, in his opinion, training should be a territorial function. His 
The Southern Rhodesian contingent based their arguments for unification on the premise that merging the health services was both feasible and practical. In addition to the benefits for medical training, the delegates argued that federating health would provide better responses to epidemic diseases, more coordinated polices in tackling endemic disease, and greater efficiencies in procurement and disbursement of medical equipment and drugs. Furthermore, they declared that a federal body was best suited for securing the borders of the federal territories against immigrant importation of disease, coordinating research, and for dealing with international entities such as the World Health Organization. ${ }^{39}$

The one disease that all delegates agreed should not be included in any federal control of health was silicosis, a growing health problem within the mining industries of Southern and Northern Rhodesia. After much discussion, participants at the meeting agreed that there were too many differences in the ways in which each territory handled the issue for any benefit to accrue from unifying the service. First, the mining industry itself differed in that Northern Rhodesia's was composed of large clustered mines while Southern Rhodesian mines tended to be small and scattered. Second, Northern Rhodesia had established the Medical and Research Bureau in 1945 and enacted legislation requiring medical screening for all employees at the start and end of their employment. Southern Rhodesia had its own legislation. Lastly, the nature of compensation differed.

perspective may well have been encouraged by the relative robustness of training of auxiliaries in Nyasaland. Medical auxiliaries from Nyasaland had been employed throughout Central Africa since the early colonial period and enjoyed an enhanced reputation for their medical skills. Ibid.

${ }^{39}$ Ibid., 10. 
After a discussion of these differences at the Lusaka meeting, Morris declared it was "beyond the whit of man to codify the two acts which are at present in force."40

What is interesting about this decision to leave silicosis to the territorial governments is that it was based on the premise that the different approaches of the territorial governments towards the disease made it impractical to bring the issue under the federal umbrella. In fact, the same argument could have been made for health as a whole. Legislation of health differed, in that Southern Rhodesia had a medical board to oversee the registration of medical practitioners and state registered training programs, while Northern Rhodesia did not. In addition, the staff of the two health care systems had different terms and conditions with differing rates of remuneration. What may have been the crucial factor for silicosis was the question of compensation and the degree to which the federal government was prepared to assume any liability for payments. The extent to which that figured in the decision to leave silicosis under territorial control is unclear.

The meeting in Lusaka did secure agreement between all delegates that federating health was justified, at least on practical grounds. The three senior health officials concurred that unification would be the most cost effective way of providing health services and that a Health Minister should have the services of an advisory board with representation from all three territories. Furthermore, importantly, all participants agreed that the African would not notice any difference in service. Lt Col E.M. Wilson, the Northern Rhodesian Member for Health and Local Government and chairman of the meeting, said the "African in the village would [not] realize anything had happened at all. He would just go quietly on in the same way to his clinic, and if he were sick he would be

40 Ibid., 11. 
picked up by the nearest ambulance and taken to the nearest hospital in the same way as at present...and he would not be able to care less.. ${ }^{41}$ This assertion assumes that a centralized policy would not bring about changes in priorities, and that funding for individual clinics or hospitals would continue at a similar level. Given that clinics and rural hospitals throughout the colonial period were often faced with the threat of closure due to lack of available staff or funding issues, this was a bold assumption. ${ }^{42}$ In addition, it seems that while Wilson was aware of African antipathy towards the prospect of a Central African Federation, he underestimated the amount of distrust that came to shape relations between many Africans and federal officials in the northern colonies.

Wilson's assertion also underscores the extent to which the entire quest to bring health under the federal umbrella was less about actual provision of healthcare and more about impressing the Colonial Office in London that a white settler controlled federal government could be trusted with a function so integral to Africans' everyday existence. This was an important part of white settler nation-building aspirations and illustrates how the perceived success of the health service could serve as justification for white settler minority rule and pave the way for the Federation to be awarded dominion status within the empire.

The meeting broke up having secured agreement for federating health but without clear recommendations from the delegates to their respective governments. Only

41 TNA CO 1015/634: "Record of a Meeting on the Unification of the Health Services in Southern Rhodesia, Northern Rhodesia, and Nyasaland," 6-7.

42 The rural clinic system set up in the early 1930s in Southern Rhodesia foundered because of a lack of funds and personnel. Mission hospitals and clinics in, which provided the bulk of rural care in all three territories with the help of grants from the colonial governments, often struggled with the same issues. Glen Ncube, "The Making of Rural Healthcare." 
Fletcher, as the Minister for Health in Southern Rhodesia, had the authority to accept any recommendation for the unification of health on behalf of his government. The representatives from Northern Rhodesian and Nyasaland could not do the same. The Nyasaland Director of Medical Services, Mackenzie, made it clear that he had no authority to commit the Nyasaland government to any decisions on whether health should be federalized. Wilson, the Northern Rhodesian delegate, was concerned about the political ramifications of federating health and recommended that further consultation was needed before his government could make a decision as to whether to formally support the measure. ${ }^{43}$

After the meeting, the territorial governments expressed their formal views on the matter. As expected, the Southern Rhodesian government endorsed the idea that the health services should be federalized, saying, "health services would be unworkable except on a Federal Basis." It based its argument on economics, saying that given the expense of running a national health service, it was unlikely that individual territories could continue to maintain the present level of service let alone carry out any expansion without the need for large increases in taxation. ${ }^{44}$ In contrast, the Nyasaland government maintained its commitment to health being a territorial concern as conceived in the original division of functions produced at the officials meeting in London, in $1951 .^{45}$ The Northern Rhodesian government formally acknowledged the practical and technical benefits that could emerge from federating health but considered the importance of the

43 TNA CO 1015/634: "Record of a Meeting on the Unification of the Health Services in Southern Rhodesia, Northern Rhodesia, and Nyasaland," 5. ${ }^{44}$ TNA CO 1015/634: Letter from Nigel Parry, Central African Council, to the UnderSecretary of State for Commonwealth Relations, April 10, 1952, 2-3. 45 Ibid., 3 
political ramifications merited further debate at the upcoming London conference in April. ${ }^{46}$

The following month, the London conference decided how the various functions, including health, would be divided between the federal and territorial governments within the Federation. In 1951, a straightforward division between federal and territorial responsibility had been proposed. However, the Rhodesian Prime Minister, Godfrey Huggins had later put forward a case for a concurrent list of legislation. The concurrent list would contain those functions that came under the remit of both federal and territorial legislatures. ${ }^{47}$ Importantly, though, if the territorial law conflicted with the federal law then the federal legislation would prevail. ${ }^{48}$ Thus the federal constitution would consist of an exclusive Federal Legislative list and a Concurrent Legislative list.

The white, settler faction of the Southern Rhodesian delegation to the April London conference used the conclusions of the Lusaka meeting to argue for health to be placed on the exclusive Federal Legislative list. When this proved to be too difficult, they successfully pushed for it to be put on the Concurrent Legislative List. The placement was a compromise between the desire to keep African affairs within the remit of the territorial legislatures and the presumed technical benefits of a unified service. The point that carried the day was the view that Africans would not notice any difference in the way they received health care. ${ }^{49}$

\footnotetext{
46 Ibid.

${ }^{47}$ Advisory Commission on the Review of the Constitution of the Federation of Rhodesia and Nyasaland, Survey of Developments Since 1953: Cmmd. 1149 (London: Her Majesty's Stationary Office, 1960), 3.

48 Wood, The Welensky Papers, 233.

${ }^{49}$ Ibid., 256-7.
} 
The placement of health on the Concurrent Legislative list was an important step in the process of federating health. It meant that when the Territorial Laws Amendment Act was passed in the Federal Assembly in 1954, the federal government could assume control for health along with any other function that had been placed on the concurrent list. ${ }^{50}$ The act enabled the federal government to take over responsibility for any service that was deemed to fall within the federal sphere. This included non-African agriculture, copyright, weights and measures, and public health. ${ }^{51}$ By the end of 1954 some fourteen functions, including health, had been removed from the concurrent list and placed under the complete control of the federal government.

There is evidence to suggest that the Territorial Laws Amendment Act was a deliberate move on the part of the federal government to assume control of as many functions as possible with the goal of creating a unitary state in Central Africa. In June 1956, Sir Arthur Benson, Governor of Northern Rhodesia, sent a scathing missive to his superiors in the Colonial Office criticizing the centralizing policies of the federal government. ${ }^{52}$ Benson pointed to the complete lack of negotiation that had accompanied the federal take over of functions such as health. Benson said that bills deleting territorial jurisdiction were presented to the territorial governors as fait accompli. In his opinion, the centralizing policies were designed to ensure that the Concurrent Legislative list would cease to exist and thereby necessitate changes in the overall constitution of the Federation well ahead of the constitutional review scheduled for 1960. The chairman of the

50 Advisory Commission, Survey of Developments since 1953, 3-4.

51 Ibid.

${ }^{52}$ Benson to Lennox-Boyd, June 6, 1956, TNA 1015/1129. 
Nyasaland Federal Party summed up the ambitions of the federal government when he announced at a meeting,

"I am informing this Committee off the record that leading Europeans in the Federation and the Federal Government, ably led by Sir Godfrey Huggins, have only one object in view - that is, over the course of the next few years to federalise every department in the Territorial Governments and vigorous steps are being taken already to pave the way to complete amalgamation. It is a question of holding on until then.".53

The chairman's view highlights the importance of federating government functions to the nation-building aspirations of the ruling white settler elite. The assumption of a large "big-spending" department such as health could confer legitimacy on a government whose long-term aim was a white state in Africa. ${ }^{54}$ This perspective explains why the Southern Rhodesians approached the negotiations over the question of federating health with such forcefulness. It should be acknowledged that the senior medical personnel largely agreed that unifying health would bring certain benefits. However, it was problematic from a political perspective. The lack of awareness on the part of the British officials that health was to become a federal function demonstrates the backhanded way in which the Southern Rhodesians approached the issue.

\footnotetext{
${ }^{53}$ P.F. Brereton, speech at a meeting of the Nyasland Federal Association, Feb 27, 1954, qtd in CO 1015/1129: "Northern Rhodesia," letter from Sir A Benson to Mr LennoxBoyd in British Documents on the End of Empire: Central Africa, Part I: Closer Association 1945- 1958, edited by Phillip Murphy (London: The Stationary Office, 2005), 331.

${ }^{54}$ In the negotiations over federating health, Huggins stressed the importance of federating a big department. Huggins said that it would make Federation more acceptable to the white Southern Rhodesians for reasons he didn't make clear. Wood, Welensky Papers, 97.
} 
One hurdle facing the newly created Ministry of Health in the months prior to the federal assumption of health was how to mold together the very different medical services of the Northern territories with that of Southern Rhodesia. Most significant was that the medical professionals in the Northern Rhodesia and Nyasaland services were part of the London administered colonial medical and nursing services while those in Southern Rhodesia were a part of a locally based and recruited service. The services had evolved along very different lines.

The expatriate medical staff of the government services of Northern Rhodesia and Nyasaland was part of an empire-wide colonial medical service. British doctors and nurses who desired to work abroad applied to the colonial medical service or the overseas nursing service in London and were posted according to imperial needs. A career in the colonial medical service often encompassed a number of appointments in different parts of the empire. Opportunities for promotion often came by way of a transfer to a different service in another colony. Nevertheless, some colonial doctors stayed with one territorial service or at least within one region, for many years. Dr William Petrie's career is a good example. Petrie originally came to Africa as a missionary doctor, working in Nyasaland from 1938. After serving in the King's African Rifles during the Second World War, Petrie joined the colonial medical service in 1946 and returned to Nyasaland where he stayed until he left the service at the end of $1957 .{ }^{55}$ The medical services of Northern Rhodesia and Nyasaland often struggled to recruit sufficient personnel. This was a

55 “Introduction," William Oliver Petrie Papers, National Library of Scotland (NLS). 
perennial problem not helped by the low status afforded the services in those colonies compared with more prestigious postings in West Africa, Sudan, or India. ${ }^{56}$

In contrast, the government medical service in Southern Rhodesia was a locally based service that accepted applications directly and processed them either in Salisbury, the colony's capital, or at Rhodesia House in London. The service also recruited widely from South Africa and from its locally based nursing school. Even though the nursing service had a rapid turnover due to a policy requiring resignation of women upon marriage, the doctors and nurses of the Southern Rhodesia medical service tended to be part of a settler community and viewed Southern Rhodesia as their home. ${ }^{57}$ A defining feature of the Southern Rhodesian nursing service from the Second World War onwards was its growing reliance on temporary nurses due to its marriage policy. The nursing service rehired women who wanted to return to work but never as permanent staff. ${ }^{58}$

The services also differed because the racialized and gendered professional hierarchy that was a feature of colonial medicine was more marked in the medical service of Southern Rhodesia than in those of the northern colonies. The bigger European

\footnotetext{
${ }^{56}$ Anne Crozier, Practising Colonial Medicine: The Colonial Medical Service in British East Africa (London: I.B.Tauris, 2007), 22.

${ }^{57}$ The policy of making nurses leave on marriage was standard in Britain, America, and in most western countries for much of the twentieth century. While incoming doctors to the Federation can be regarded as settlers, it is important to note that a feature of some of European population of Southern Rhodesia was its relatively transient nature. Josiah Brownell has argued that some immigrants are better viewed as sojourners given their propensity to move from colony to colony as opportunity presented. Josiah Brownell, "The Hole in Rhodesia's Bucket: White Emigration and the End of Settler Rule." Journal of Southern African Studies 34, 3 (2008): 592. Alois Mlambo also notes the high rate of turnover of settlers in the colony. Between 1921 and 1964, out of every one hundred settlers who arrived in the colony another sixty-seven left. Nintey-two percent of immigrants were of British origin in the early colonial period dropping to fifty percent after the Second World War. Mlambo, History of Zimbabwe, 79-80.

${ }^{58}$ Masakure, "One of the most Serious Problems," 119-120.
} 
population with its comparatively larger numbers of white professional nurses precluded the use of non-European doctors because of the desire to maintain supremacy of white over black. ${ }^{59}$ Hospitals were segregated clinical spaces in which African nursing orderlies, who were overwhelmingly male, did not care for European patients. The top level of the medical hierarchy was the preserve of white, male, medical doctors, usually trained in British medical schools. The next rung was composed of white, female, professionally qualified nurses while locally trained African auxiliaries provided the supporting base.

A further difference in the medical services of Southern Rhodesia and the northern territories is that in the former there was a clear demarcation between curative and preventative medicine that did not exist to the same extent in the latter.

Administratively in Southern Rhodesia, preventative medicine was a separate department with its own cadre of African hygiene demonstrators. The demonstrators' work consisted mainly of health education and assisting with campaigns such as anti-malarial spraying, water treatment, and vaccinations. The department worked closely with the local Native authorities in the African reserves. In contrast, in Northern Rhodesia and Nyasaland, preventative medicine was merely one facet of a colonial medical officer's job. A

${ }^{59}$ John McCracken suggests that in Nyasaland, Asian sub-assistant surgeons had a higher place than white nurses in the colonial medical hierarchy. Shula Marks has described the difficulty the entrance of African doctors into the workplace posed for the medical hierarchy in South Africa. McCracken, History of Malawi, 262; Marks, Divided Sisterhood, 149. 
colonial doctor went on "safari" visiting rural clinics and dispensaries and attended to curative and preventative functions simultaneously. ${ }^{60}$

The government medical service of Southern Rhodesia was also part of a larger medical community that included private medical practitioners and nurses serving the European community. For the most part this did not exist in either Northern Rhodesia or Nyasaland. The exception was on the Copperbelt of Northern Rhodesia where mining corporations provided health services for their employees and a growing, but still small, European population encouraged some medical practitioners to set up private practice.

Conditions of service also differed considerably. Officers serving in the Northern territories were eligible for retirement on a full pension earlier, had more generous housing allowances, and generally better salaries. However, those in the Southern Rhodesian service had more opportunities to supplement their salary through private practice. The services in Northern Rhodesia and Nyasaland also provided a generous amount of tour leave. Officers going on leave usually returned to Britain and could be away from their postings for up to three months every two or three years. This tended to create temporary difficulties of staffing especially when other medical posts were vacant. In one year, four of Nyasaland's medical officers, including the Director of Medical Services, were on leave when three other posts were vacant. As result the service operated with just two-thirds of its staff. ${ }^{61}$

${ }^{60}$ For an example, see: John Goodhall, Goodbye to Empire: A Doctor Remembers (Haddington Scotland: The Prentland Press, 1987).

61 The National Archives (henceforth 'TNA'), CO/1015/1090: D. J. M. Mackenzie to J. C. R. Buchanan, March 12, 1954. 
By the eve of federation, then, the territorial medical services had evolved along divergent paths. The federal Secretary of Health, Morris, imagined a federal medical community united in purpose and values. ${ }^{62} \mathrm{He}$ was deeply mistaken. The process of federating health sowed seeds of distrust and suspicion amongst African and European staff from the outset. In particular, the medical staff of Northern Rhodesia and Nyasaland appeared to view the proposed merger as a loss of professional autonomy and resented what was viewed as the subsuming of their territorial services into a Southern Rhodesian medical service.

Furthermore, Morris underestimated the extent of African antipathy to the concept of federation, which biased African medical personnel against working in the federal service. Africans had been vociferous opponents of any sort of closer union between the colonies of Central Africa. Opposition was strongest and most sustained in Nyasaland and Northern Rhodesia but anti-federation sentiment in Southern Rhodesia was particularly virulent prior to the start of federation. ${ }^{63}$ Collaboration between African organizations of the three colonies resulted in the formation of an All-African Convention to oppose federation. ${ }^{64}$ While it was not successful, African opposition continued unabated throughout the period of federation, most noticeably in the northern territories. In Southern Rhodesia, anti-federation sentiment waned as the imposition of federation

\footnotetext{
62 The Federation of Rhodesia and Nyasaland, Annual Reports on Public Health, 1958, (BOA), 1.

${ }^{63}$ West, The Rise of an African Middle Class," 190.

${ }^{64}$ Mlambo, "From the Second World War to UDI," in Becoming Zimbabwe, 110.
} 
became inevitable and elite Africans, at least for a while, pursued a policy of accommodation with the white settler elite. ${ }^{65}$

The move of the federal government to appropriate health appeared to unnerve colonial medical officers in the field and clearly took officials in the colonial medical service at the British Colonial Office by surprise. In the early months of federation, Dr. Robinson, the Director of Medical Services of Northern Rhodesia, joined his counterparts in the Nyasaland and Southern Rhodesian services on a tour of the Federation as part of a working party formed to investigate the best way of merging the territorial medical services. On his return to his headquarters in Lusaka, Robinson wrote to his colonial medical officers about the changes to working conditions that his officers would experience when health "went federal. ${ }^{, 66}$ Robinson wrote the circular far in advance of the date that the federal government was due to take over responsibility for health, known colloquially within the service as "D-day," and demonstrates that there was a great deal of speculation over what the change in administration could entail. Robinson also sent a copy to Dr. Buchanan of the Colonial Office in London. Here, the missive generated a great deal of discussion about how the federal assumption of health would affect the officers in the field but also its impact on the colonial medical service as a whole. A number of commentators at the Colonial Office appeared to be completely unaware that health was to become a federal function and the responses to the circular reflect the air of uncertainty and suspicion that the process of federating health generated. ${ }^{67}$

65 West, The Rise of an African Middle Class, " 191-2.

66 TNA CO/1015/1090: P.B Robinson, H.D. Circular No. 60, December 3, 1953. 67 TNA CO/1015/1090: 1-5. 
Buchanan expressed a number of reservations about the proposed reorganization of the health services. A primary concern was that the administration in London would be inundated with requests for transfers from officers in the field who did not want to work in the federal service. This was a potential problem for the colonial medical service as the shrinking empire meant fewer posts were available to absorb those officers who wanted to leave Central Africa. In addition there was unease about the rigor of the Southern Rhodesian recruitment process. In Buchanan's view, the colonial medical service demanded a higher caliber of candidate than did the Southern Rhodesian service but Morris, who was to be Secretary for Health in the federal service, was intent on using the Southern Rhodesian process for federal recruitment. Furthermore, Buchanan viewed with disquiet the empire-building tendencies of Morris. Morris did not want to appoint a federal deputy, was intending to retain control of the Southern Rhodesian branch of the federal service, and would have direct control over the branches in the northern territories. Effectively, the federal the Southern Rhodesian headquarters would become the same entity, giving the impression that the process of federating health was more an absorption of the northern services into the Southern Rhodesian service than a unification or process of federation. ${ }^{68}$

A core issue for European officers in the field was the very different conditions of service enjoyed by government medical officers in Southern Rhodesia and those in the colonial medical service. Those in Southern Rhodesia seem to have generally welcomed the unification of the service because, according to the Colonial Office, there was a

68 TNA CO/1015/1090: Buchanan, "Observations on the Process of Federating the Medical and Health Services of Rhodesia and Nyasaland," January 5, 1953. 
perception that their service conditions would be raised to match those of the "pampered Colonial Service. ${ }^{\prime 69}$ The reaction of medical officers in Northern Rhodesia and Nyasaland was markedly different. In addition to losing generous service conditions relating to leave, housing, and paid passages home, they believed that they were sacrificing the opportunities of being part of a unified, medical service offering opportunities throughout the empire. ${ }^{70}$ In his circular, Robinson cautioned his medical officers to consider their future carefully and suggested that the wisest course might be a wait and see strategy until such time as the federal terms became known and the pros and cons of transferring permanently to the federal service could be properly weighed. ${ }^{71}$

A further source of distrust and resentment was the lack of any concrete information about the proposed federal terms on offer even as "D-day" set for no later than July $1^{\text {st }} 1954$, neared. ${ }^{72}$ Each post was to be individually assessed as to equivalency of grades, salary, and other conditions of service with a comparable existing post in the Southern Rhodesian service. ${ }^{73}$ There simply wasn't enough time for a task of this magnitude to be taken in the few months available to the commission appointed to carry out the work, before the federal government was due to take over. This affected colonial officers' ability to make an informed decision about whether to accept federal terms or not as they were essentially flying blind.

The vacillation also created difficulties in recruitment for posts that were already vacant. Nyasaland was in need of at least three medical officers but recruitment had thus

\footnotetext{
69 Ibid.

70 Ibid.

71 TNA CO/1015/1090: P.B. Robinson, H.D. Circular No. 60, December 3, 1953.

72 Dr. J.M. Mackenzie to Dr. Buchanan, March 3, 1954.

73 Ibid.
} 
far been unsuccessful. According to the Director of Medical Services, Mackenzie, the Colonial Office had promised to do its best to fill the vacancies but it could not guarantee that the usual quality of candidate would be maintained. In conversations between Mackenzie and Morris concerning the vacancies, Morris said that he was currently recruiting medical officers for Southern Rhodesia and that assuming there were more candidates than available jobs, then perhaps some candidates might be persuaded to take federal terms and go to Nyasaland. Understandably, Mackenzie was of the opinion that the needs of his service in Nyasaland were being marginalized. ${ }^{74}$

In the event, all employees of the territorial medical services were transferred on a temporary basis to the federal service. ${ }^{75}$ The temporary transfer was for five years and ensured that the federal health department could continue to function while federal service conditions and pay were determined. The hope of senior officials within the federal health department was that most personnel would make their temporary placement permanent once they had received formal notification of federal terms of service. $^{76}$

The terms of the temporary transfer privileged the European staff. They could resign at any time and receive financial compensation for the loss of their territorial

74 Ibid.

75 This was referred to as secondment and was part of a larger secondment of all territorial civil service employees including workers in health, communications, post offices etc. to the relevant newly created federal departments. Survey of Developments Since 1953: Cmmd. 1149, 58.

76 The transfer of health to the federal government meant that all territorial positions were effectively abolished. This was laid down in Articles 9-11 of the Federal Constitution and covered all federal government officer positions in the civil service of which medical officers were a part. Report of The Commission of Inquiry into the Health and Medical Services of the Federation 1959 (Salisbury: The Government Printer, 1960), 7. Henceforth, 'The Morton Commission.' 
post. $^{77}$ African government employees, too, could resign at any time but they were not entitled to the same compensation. Many did not want to work for the federal government and many African federal employees, including medical workers, resigned rather than work for the federal government. This was despite the lack of alternative employment in some areas. Some proceeded to devote their time to anti-federal activities. ${ }^{78}$ Malawian doctor Austin Mkandawire who trained as a medical assistant in 1950, wrote in his memoir that most auxiliaries did not want to work for the federal government. However, he also recognized that for many, resigning in protest was not an option and that individual material conditions drove their decision to resign or to "stick it out." ${ }^{, 79}$ Even so, an astonishing fifty-six percent of African medical staff in Nyasaland refused to transfer to the federal staff. ${ }^{80}$

The temporary transfers created problems for the federal service administrators. Officers could choose to either transfer permanently to the federal service or retire at any time prior to the expiry of the transfer period. This made it difficult for the service to forecast recruitment needs. It also contributed to an ongoing chronic shortage of professional biomedical expertise as officers took advantage of the generous monetary

77 Ibid.

78 Owen Kalinga, "The 1959 Nyasaland State of Emergency in Old Karonga District," Journal of Southern African Studies 36, 4 (2010), 751.

${ }^{79}$ Austin C. Mkandawire, Living My Destiny, A Medical and Historical Narrative (Glasgow: Dudu Nsomba Publications, 1988), 128.

${ }^{80}$ McCraken, A History Of Malawi, 263. 
compensation available. This would create problems for the federal service as it attempted to build a "great health service" in the years to come. ${ }^{81}$

${ }^{81}$ This phrase is borrowed from the editorial of the CAJM on the demise of the Federal Health Service in 1963. The editorial lamented the "passing of a great health service." "The Passing of a Great Health Service," CAJM, 9, 10 (1963), 411. 


\section{Chapter Three.}

\section{Creating a "Great Health Service," 1954 - 1958}

The federal government assumed responsibility for providing health services on the first day of July 1954. The health department set about creating a health service befitting the government's view of the Federation as a modern, rapidly developing nation. In this vision, the hospital loomed large. It was visible evidence of the Federation's intention to improve the health of its people but also functioned as a marker of modernity. ${ }^{1}$ At the same time, the health service looked to expand training of African medical personnel. Providing career opportunities for Africans provided proof of the Federation's commitment to "partnership." The reality was rather more checkered. The uncertainties and suspicions that federating health had fostered, persisted and grew in the early years of the Federation. Staff turnover was high causing instability and prejudicing the formation of a unified medical community. In addition, the health service pursued policies that raised concerns from the wider public about its ability to address local needs and contributed to the growing marginalization of Northern Rhodesia and Nyasaland.

Central to the health department's imagination of a national health service was the construction of significant infrastructure. As a consequence, the department launched an ambitious schedule of hospital and clinic building in urban and rural areas. The emphasis on improving healthcare facilities was important to the federal government because it was one way in which the Federation could appear to be a legitimate candidate for greater political autonomy from Britain. The ability to provide improved health care could

\footnotetext{
${ }^{1}$ Wendland, Heart for the Work, 8.
} 
demonstrate that the federal government was capable of taking over the Colonial Office's role in looking after the interests and welfare of its African subjects and so strengthen the case for eventually attaining dominion status within the empire.

The federal health department inherited development plans for new hospitals from the colonial governments. Each government had started construction of substantial hospitals for their African populations in major cities. Two were in Southern Rhodesia, one on the Northern Rhodesian Copperbelt, and one in Nyasaland. The hospitals became showcases for the Federal Health service's professed commitment to improve healthcare and became symbols of the biopolitical face of the Federation and its intention to promote life and health in its population. ${ }^{2}$

From the Health Ministry's perspective, the completion of the hospitals represented the pinnacle of achievement for the health service. ${ }^{3}$ No matter that they had been conceived of prior to federation. The federal government claimed the credit. The opening ceremony of each was a lavish affair, attended by the Governor-General of the Federation, Lord Dalhousie, senior government ministers, and prominent European and African dignitaries. In his opening speeches, Lord Dalhousie emphasized the magnificence of the buildings and pointed to the hospitals as symbols of the "growing civilization of this young country" and as evidence of the federal government's intention

${ }^{2}$ On the biopolitical guise of the colonial state see Nancy Rose, A Nervous State: Violence, Remedies, and Reverie in Colonial Congo, 7-9. The symbolic importance of hospitals to the Federal service is evident in the renaming of health care facilities that occurred in 1959. Under the new nomenclature, any building with at least ten beds was known as a hospital. The Federation of Rhodesia and Nyasaland, Annual Reports on Public Health, 1959 (BOA), 13.

${ }^{3}$ All four hospitals were completed and opened in the same year, 1958. 
to provide more health facilities across the Federation. ${ }^{4}$ The pomp and circumstance that surrounded the opening of the African hospitals also illustrates the centrality of the hospital in the settler vision of health. In each of the speeches at the various opening ceremonies, Lord Dalhousie emphasized the hospitals as sites of technological expertise being equipped with specialized departments of medicine and surgery but also as a haven for the sick to recover and reclaim their place in society. ${ }^{5}$ Paying attention to the moral economy underlying these speeches illustrates the extent to which the political economy of health had shifted since the early colonial period. Rather than primarily privileging the health of Europeans and African laborers, the developmental ethos that emerged in the wake of the Second World War viewed healthier African societies as crucial to the success of the colonial state. ${ }^{6}$

The hospitals also demonstrate that there was a growing emphasis on a limited number of large hospitals in the 1950 s. $^{7}$ The hospitals were designed to serve as the central referral facility for surrounding settlements. In practice, this meant development

4 "The Opening of the new Harari African Hospital," CAJM, 4, 5 (1958), 223. "The Opening of the new Mpilo African Hospital," CAJM, 4, 9 (1958), 401. Claire Wendland makes the point that hospital buildings can be used as a measure of a nation's modernity or of a commitment to health. Wendland, A Heart for The Work, 8.

5 "The Opening of the new Harari African Hospital," CAJM, 4, 5 (1958), 223. "The Opening of the new Mpilo African Hospital," CAJM, 4, 9 (1958), 401.

${ }^{6}$ Randall Packard, "Visions of Postwar Health and Development and their Impact on Public Health Interventions in the Developing World," in F. Cooper and R.M. Packard, International Development and the Social Sciences, (Berkeley: University of California Press, 1997), 93-118.

7 The increased centralization of services in large, urban hospitals was replicated in much of colonial Africa, simultaneously reflecting the growing urbanization of African populations and the growing status of hospitals as prestigious sites of medical research and education in the United States and Europe. Roy Porter, The Greatest Benefit to Mankind: A Medical History of Humanity (New York: W. W. Norton \& Co., 1999), 647649. 
plans for smaller hospitals in neighboring towns were often shelved, raising concerns about the willingness of the federal health department to pay attention to local needs. As one federal MP questioned, "are we serving the population or are we serving the name of a town or one particular Ministry?" ${ }^{8}$ In particular, the construction of the Kitwe hospital in Northern Rhodesia angered residents and local authorities in the neighboring town of Ndola. When building started in Kitwe, it soon became apparent Ndola was not going to get a replacement for the very dilapidated existing African hospital. Elite Africans and the town council launched a scathing attack on the federal Ministry of Health and on Federation itself. This was noteworthy because the platform for this attack was the normally pro-Federation newspaper, The Northern News.

The existing African hospital in Ndola was over 20 years old and in a state of extreme disrepair. When the Ndola council asked the federal government for a new hospital, the request was refused on the grounds that funds had been committed elsewhere. ${ }^{9}$ Throughout the winter of 1955 , the Northern News carried ever more emotionally charged articles depicting the deplorable conditions at the hospital. One article described the hospital like a "scene from the Crimea." ${ }^{\prime 10}$ Another suggested that the federal government's refusal was the "high price of Federation." A third asserted that the

8 Federation of Rhodesia and Nyasaland, Federal Assembly, "Health and Medical Services," Debates of the Federal Assembly (Salisbury: Government Printer, April 9 1960), 756.

${ }^{9}$ Private Secretary to Minister of Health to Private Secretary to Minister of Transport and Communications, May 13, 1955, Welensky Papers, Box 358.

10 "Tour of Ndola African Hospital like a scene from the Crimea," Northern News, June 16, 1955, Welensky Papers, Box 358. 
federal government was "morally bound to ... build this hospital." ${ }^{\text {"11 }}$ Editorials and columnists argued that the failure to provide funds for a new hospital would stall the future development of Ndola and of the colony as a whole. One editorial said,

"Let the [Health] Minister and his Department understand clearly that treatment of this kind is NOT acceptable. Unless health services (particularly hospitals) with roads and education are adequate to the need, the development of this country is endangered. In cases as urgent as Ndola's the excuse that there is no money is just not acceptable. The money simply must be found." 12

When an outbreak of smallpox occurred in the midst of the furor, critics of the federal government were quick to say that the epidemic was inevitable given the conditions in the hospital. One editorial was particularly critical, saying that the government had been fully aware of the deplorable state of the hospital at the start of 1954 and twenty months later nothing had been done. ${ }^{13}$ In the event, the African residents of Ndola never got their new hospital during the federal period. It was still on the backlog of construction when the Federation was dissolved in $1963 .{ }^{14}$

The large central hospitals that were built also demonstrate that clinical spaces in the Federation remained deeply segregated. Mpilo and Harari hospitals in Southern Rhodesia only treated Africans. While the hospitals in Northern Rhodesia and Nyasaland were nominally multiracial, there were separate wards and even separate kitchens for the

\footnotetext{
11 "High price of Federation," Northern News, June 16, 1955, Welensky Papers, Box 358; "We must be up and doing," Northern News, June 21, 1955, Welensky Papers, Box 358. 12 "The hospital must be built," Northern News, June 15, 1955, Welensky Papers, Box 358.

13 “The warnings were in vain," Northern News, September 22, 1955, Welensky Papers, Box 358 .

${ }^{14}$ The Federation of Rhodesia and Nyasaland, Annual Reports on Public Health, 1963 (BOA), 14.
} 
preparation of patients' food. ${ }^{15}$ This policy persisted despite acknowledgements from the Minister for Health that such arrangements were far more inefficient and costly to provide than integrated services. ${ }^{16}$ It seems that although funds could not be found to replace seriously deficient African hospitals, money was available to provide services in a way that maintained the settler colonial order of segregation.

The opening of the hospitals also allowed the Federal Health Service to claim that it had fulfilled a longstanding promise to offer state registered nurse training to African women. Calls for state registered training of African nurses actually predated federation by at least a decade. In the late 1930s, European patients, nursing staff, and elite Africans all urged the medical director in Southern Rhodesia to start training African nurses. ${ }^{17}$ The ethos behind these calls was that by training African nurses, there would be more European nurses available to care for white patients. It was never envisaged that African nurses should directly care for white bodies. ${ }^{18}$ As already noted, there was a chronic shortage of qualified nurses exacerbated by a restrictive labor policy that kept professional nursing as the preserve of white women and policies that insisted nurses resigned when they got married. ${ }^{19}$ The Federal Health Service, then, inherited a chronic and continuing problem. The expansion of the service to include health care provision for the entire Federation only made matters worse. Prior to federation, the Southern

15 “Llewellin Hospital: Kitwe," CAJM, 4,12 (1958), 556.

16 Federation of Rhodesia and Nyasaland, Federal Assembly, "Health Services: Separate Services," Debates of the Federal Assembly (Salisbury: Government Printer, August 9 1961), 641-642.

17 Masakure, "One of the most serious problems confronting us at present", 128. 18 Ibid.

19 Southern Rhodesia enacted legislation in the 1930s to protect white workers from African competition. Ibid. 
Rhodesian service directly recruited its nursing staff from both within and outside of the colony. In contrast, the medical services of Northern Rhodesia and Nyasaland had access to an empire-wide labor pool of nursing staff managed by the colonial nursing service in London. A change in policy within the colonial nursing service meant that by the early 1950s, applicants to the service were only offered positions in those colonies that did not have their own training schools. This excluded dominions and colonies such as Australia, New Zealand, Canada, and Southern Rhodesia. When the federal government took over responsibility for healthcare provision, it also took over the recruitment of its medical staff. Hence Nyasaland and Northern Rhodesia were removed from the colonial nursing service list of available postings for recruits. This narrowed the pool of potential recruits for those colonies.

All of the large central urban hospitals were designed with the intention that they should become sites for training professional African nurses. However, on their completion, training was restricted to those hospitals built in Southern Rhodesia. Why the federal health department did not start state registered training in the northern territories is not entirely clear. For political reasons, the initiation of state registered nurse training for Africans at multiracial hospitals (but with segregated wards and kitchens etc), would have reflected well on a federal government that was supposed to be committed to the creation of a multiracial society. ${ }^{20}$ In the case of the hospital in Nyasaland, one excuse

20 Senior nursing officials in London later acknowledged this point after a visit by the federal Secretary for Health. M. Henry, "Note on Interview with Dr. Blair," February 2, 1962, TNA, DT 18/686. 
given was the lack of sufficiently educated applicants. ${ }^{21}$ This is plausible given the long neglect of colonial governments to provide education for their African populations. But just a few years later, after gaining independence, Malawi opened a school on the premise that they had enough qualified applicants making that excuse less credible. ${ }^{22} \mathrm{~A}$ second reason expressed was that the hospital did not offer sufficient diversity in care to provide proper training. ${ }^{23}$ This is somewhat surprising given that the hospital was one of the four celebrated at its opening as a site of modern, biomedical expertise. In the case of the Kitwe hospital in Northern Rhodesia, promises were continually made but training never materialized. ${ }^{24}$ The excuse was that the school did not have formal recognition from the General Nursing Council (GNC) in Britain. While recognition was considered important because it conferred legitimacy on the training program, it was not essential. The primary reason for pursuing recognition was that graduates would be qualified to work in British hospitals. ${ }^{25}$ Given the shortages in the federal nursing service, recognition conferring the

${ }^{21}$ The Federation of Rhodesia and Nyasaland, Annual Reports on Public Health, 1958 (BOA), 22 "National School of Nursing," CAJM, 11,9 (1965), 271.

23 "Consideration of the Report of Commission of Inquiry into Health and Medical Services," Debates of the Federal Assembly, April 13, 1960, 763.

${ }^{24}$ Mr. Yamba, African Federal MP for Northern Rhodesia, argued that training of nurses should be carried out in Kitwe because the completion rate would be much higher if women trained within the territories that they lived. He suggested that language barriers and cultural differences could impact training outcomes. Ibid., 748.

${ }^{25}$ The practice of seeking recognition with the GNC in Great Britain was predicated on the idea that colony trained nurses would be able to work within the NHS in Britain. Faced with severe shortages within the NHS in 1949, The GNC amended registration to one that evaluated colonial and dominion hospitals on an individual basis and widened the basis under which overseas trained nurses could work in British hospitals. As Solano and Rafferty have argued, this policy facilitated the international migration of nurses. It also paved the way for a damaging loss of health care resources for some African countries in the post colonial era as nurses from ex colonies were attracted to the higher wages and better living conditions overseas. For example, over 2000 nurses migrated 
ability of federal nurses to work in Britain would perhaps have been counter-productive.

In any case, the ministry was not prepared to start training until this recognition had been received. The GNC refused to extend recognition to the Kitwe school because at the time, there was no legitimate examining body or means of medical registration in Northern Rhodesia. There was no medical council and the council in Southern Rhodesia had no jurisdiction outside of that country's borders. ${ }^{26}$ The GNC recommended that the Kitwe school should open anyway and begin training students while working towards GNC recognition but this advice was ignored. ${ }^{27}$ This inflexibility was a hallmark of health care policies in the federal era, a trait that was to become more apparent in the later years of federation. The insistence on getting GNC recognition prior to opening the Kitwe school also underscores the extent to which the senior health officials in the Federal Health Service were concerned with demonstrating that the federal service was one that adhered to international standards. This was an important part of legitimizing the decision to federate health and also conferred legitimacy on the Federation itself.

The failure to open professional nurse training schools in the northern hospitals increased the inequality of health provision within the Federation. The northern hospitals did not benefit from the contribution that students made to health care provision, a resource that became more important in the later years of the Federation. By 1962, for

from Zimbabwe to Britain between 1998 and 2004. Diana Solano, and Marie Anne Rafferty, "Can Lessons Be Learned from History? The Origins of the British Imperial Nurse Labour Market: A Discussion Paper," International Journal of Nursing Studies, 44, 6 (2007), 1055-1063.

${ }^{26}$ According to Claire Wendland, a medical council was established in Nyasaland in the 1920 s to register male medical aides and assistants who passed an approved course at Livingstonia Mission. I have been unable to ascertain if this was still in existence in the 1950s. Wendland, $A$ Heart for the Work, 43.The Morton Commission, 21.

27 M. Henry, "Note on Interview with Dr. Blair," February 2, 1962, TNA, DT 18/686. 
instance, Southern Rhodesia benefited from the labor of more than three hundred African student nurses. This number is equal to the total number of qualified nurses working in Nyasaland and Northern Rhodesia combined for that year. ${ }^{28}$ What is more, the decision not to establish professional nurse training schools in the northern territories meant that when the Federation was dissolved and Zambia and Malawi attained their independence, neither country had the capacity to train professional nurses of their own. This meant they had to enter a very competitive global market place in order to procure sufficient nursing staff. Thus the failure of the Federal Health Service to train African professional nurses in Northern Rhodesia and Nyasaland can be seen as evidence of a growing marginalization of the northern territories through policies that disproportionately benefited Southern Rhodesia.

\section{Planning a Medical School}

The architects of the Federal Health Service viewed the lack of a medical school in the Federation as a significant gap in their idealized vision of a health service. ${ }^{29}$ In part, this reflected an awareness of the role of training doctors as evidence of a modern, functional health delivery system. ${ }^{30}$ At the same time a growing international body of opinion asserted that a medical school was best established in those countries with a developed economy, a robust tax structure, sufficient investment in secondary education

${ }^{28}$ The Federation of Rhodesia and Nyasaland, Annual Reports on Public Health, 1962 (BOA), 31.

${ }^{29}$ In this context, a medical school is one that offered a course of training leading to an internationally recognized degree in medicine along the lines of programs offered in Britain or the United States.

30 Quoted in Henry R O'Brien, "The Dawn of Medical Education in Tropical Africa," Journal of Medical Education, 33, 8 (1955), 554. 
taught in a European language, and strong institutional ties to a medical faculty in the metropolis. ${ }^{31}$ From this perspective, a medical school was an important marker that a nation had reached a certain level of development. It signaled both modernity and a commitment to provision of health care. It was also evidence of a vision of health that privileged the western trained doctor as the primary locus of biomedical authority. ${ }^{32}$ The impetus for a medical school further reflected a growing pragmatic awareness within the elite federal medical community of the need to train African doctors and nurses. The federal service was simply not able to recruit sufficient European medical personnel.

The principal of the newly opened multiracial University College of Rhodesia and Nyasaland endorsed the need to train African doctors. ${ }^{33}$ At a dinner of the Southern Rhodesian Medical Association, Dr. Adams asserted that the school would encourage research into diseases of the tropics, allow a curriculum to be designed suitable for Central Africa, and lastly and most importantly, facilitate the training of African doctors. Indeed, he was of the opinion that African doctors were necessary to "provide full physical and psychological health for a population of six million Africans." ${ }^{34}$ In reply, Lord Malvern, the federal Prime Minister, said that "the government had decided that Africans should become doctors.... that there was no colour bar in disease and medicine was one of those professions that showed no distinctions." Malvern said that after Africans had completed the lengthy training, "the only decision that could be made was

\footnotetext{
31 Ibid, 555-556.

32 Wendland, A Heart for the Work, 16.

33 The college accepted its first students in 1957.

34 "Dinner of the Annual Congress of the Southern Rhodesian General Medical Council," CAJM, 2,9 (1956), 347.
} 
to accept him on the same grade [of pay] as a European doctor. ${ }^{\prime 35}$ In fact, doctors were the only Africans in the civil service who were automatically accepted into the highest branch of the Federal Civil Service after its reorganization in 1956. What is revealing about this exchange is that it both maintained the progressive idea of African advancement that was supposed to underpin "partnership" but also perpetuated the segregation that the white settler regime desired. Yes, Africans should be doctors but their role was to be that of general medical practitioners of their own people. As much as the elite medical community believed in the innate superiority of the expatriate, white, European doctor, it also realized that their parallel vision of a universal health care system in which all hospitals and at least the larger clinics contained qualified medical personnel was unattainable unless they were willing to acknowledge the potential utility of African trained doctors and nurses. Anne Laura Stoler and Frederick Cooper have suggested that colonizers altered their visions and reexamined their own hegemony when faced with difficulties and challenges of colonial rule. ${ }^{36}$ In the Central African Federation, the challenges of providing health care for six million Africans forced the elite medical community to acknowledge the need to train African doctors but within a context of a settler state, this acknowledgement seems to have been qualified and the altered vision, partial. African doctors would provide care for African patients, primarily in rural hospitals where their presence would not challenge the existing complex medical hierarchy. Indeed, the relocation of the first African doctor to work for the Federal Health

35 Ibid., 349.

${ }^{36}$ Anne Laura Stoler and Frederick Cooper, "Between Colony and Metropole: Rethinking a Research Agenda" in Tensions of Empire: Colonial Cultures in a Bourgeois World (Berkeley: University of California Press, 1997), 6. 
Service, Dr. Tichafa Samuel Parirenyatwa, to a rural hospital in the extreme southwest of the country in the "interests of race relations" supports this contention. ${ }^{37}$

By 1956, the drive towards establishing the medical school was well underway. The Nuffield Foundation in Britain agreed to fund a planning committee to advise the University College on the "desirability and practicability of establishing" such a school. ${ }^{38}$ During the following year, the committee undertook an extensive tour of the Federation visiting major towns, hospitals, and clinics. The committee's findings, drafted in two reports published in 1958 and 1959, recommended that the establishment of a medical school was urgently required to address the severe shortages of doctors in the Federation's government service. The report argued that shortages of doctors had lowered standards of care and created inequality between the numbers of doctors in major towns and those in rural areas. The committee noted that in Southern Rhodesia, the concentration of doctors in the large urban centers meant than half the doctors were serving less than five percent of the population. ${ }^{39}$ The committee also argued that training overseas did not provide the local knowledge so important for understanding the epidemiological, environmental, and social conditions in which doctors within the Federation would practice. ${ }^{40}$ The committee concluded that adding yet more

\footnotetext{
${ }^{37}$ Parirenyatwa had initially been given a position at the African Harari hospital but was moved after a short time. "Restrictions on African G.M.O.," The Debates of the Federal Assembly, July 27, 1959, 1879-1880.

38 "First Report of the Planning Committee," CAJM, 4, 6 (1956), 269.

39 Ibid.

${ }^{40}$ The field of Tropical Medicine was predicated on the exceptional conditions of the tropics. Furthermore, many commentators noted the difference in practicing medicine in Africa and Europe and that most Africans presented with a potential plethora of conditions such as malaria, hookworm, Tuberculosis, and Venereal Disease. See, for example, Michael Gelfand, The Sick African: a Clinical Study (Cape Town: Juta, 1957).
} 
infrastructure in the form of patient beds within the context of personnel shortage and without establishing proper medical training programs was akin to adding to the "superstructure when the foundations are faulty" and that it was better to "make the foundations firm and strong" thereby, over time generating a sustainable improvement in quality and quantity of health service delivery systems. ${ }^{41}$

Where, exactly, in the Federation the medical school was to be sited was a matter of some debate. While the site of the University College of Rhodesia and Nyasaland in Salisbury appeared to dictate that the Southern Rhodesian capital was the obvious choice, it was not a foregone conclusion. Livingstone and Lusaka in Northern Rhodesia and Bulawayo in Southern Rhodesia were all candidates. In the end the committee endorsed the choice of Salisbury. While building the medical school there made sense given the ties between it and the new university, the decision almost certainly further enhanced the view among Northern Rhodesian Africans of Salisbury as Bamba Zonke (take all). ${ }^{42}$ Selected as the federal capital and the principle business center, Salisbury received the lion's share of federal investment in better transport infrastructure as well as significant expansion in service industries, manufacturing, and housing. ${ }^{43}$

The proposed medical school fit the federal vision of healthcare in a number of ways. A relationship with the University of Birmingham in Britain meant its graduates could receive a British accredited degree. This ensured that they would receive the international recognition deemed so important for career advancement. It would provide a

\footnotetext{
41 "First Report of the Planning Committee," CAJM, 4, 6 (1956), 270.

42 James A Pritchett, Friends for Life, Friends for Death: Cohorts and Consciousness Among the Lunda-Ndembu (Charlottesville: University of Virginia Press, 2007), 131. ${ }^{43}$ Ibid., 130.
} 
cadre of African doctors to carry out the bulk of medical care for African patients thus providing evidence of the Federation's commitment to partnership. Lastly, its situation in Salisbury furthered the vision of the Federation's capital as the primary site of biomedical expertise. Salisbury was already home to a major African hospital, the headquarters of the Federal Health Service, and the prestigious Bilharzial Research laboratory. The placement of the medical school in the Federation's capital also promised the construction of a large university teaching hospital at some time in the future.

Furthermore, the establishment of a multiracial medical school was also a way to impress on the outside world that the Federation was a modern, fast developing nation intent on maintaining world class standards. It also illustrates the extent to which the federal leaders were aware of how the promise of healthcare and professional medical training had the potential to elevate the international standing of the Federation. On a visit to Birmingham University, Roy Welensky asserted that

"we are a British country, and because we have British standards, it is vital that the training institutions we set up in the Federation ... should be of the quality you insist upon here... I am far from unhopeful of our success, both in matching political progress to ability and in maintaining British standards. Already we have a network of hospitals and medical posts which offer to the African people of the Federation probably the finest health service on the Continent of Africa... Our medical school is a great act of faith, not only in the physical development of the Federation, but, as we take it, in the honesty of our purpose in making partnership between the races a reality for the first time in Africa....to provide training and opportunity for the men and women of our country, of whatever race, to raise them up from low standards to high, to fit them for participation in all sections of a civilised life.... That, in simple terms, is what we are doing in the Federation., 44

${ }^{44}$ The Federal Prime Minister Sir Roy Welensky at Birmingham University," CAJM, 7 $(1961,470)$. 
This rhetoric encapsulates the way in which the white settler elite appropriated the progressive language of development and African advancement to present an image of the Federation that would be acceptable to an international audience grown skeptical of colonialism and empire. It also underscores the way in which the language of qualifications and standards replaced the language of race in public life. In this formulation, access to advanced, professional medical training was open to anyone with sufficient qualifications. The reality, of course, was that, as already noted, long colonial neglect of education meant that few Africans were suitably qualified.

\section{The Failure to build a Medical Community}

The shortage of European doctors providing the impetus for the planning of the medical school was due, in part, to the deteriorating relations between the Ministry of Health and its staff. From the outset, the suspicion and uncertainty surrounding the process of federating health helped foster a geographic rivalry and an "us and them" mentality within the service. There was widespread dissatisfaction among the European medical staff with the federal takeover of health. Some European doctors in Nyasaland and Northern Rhodesia complained of the "new Rhodesian ways." ${ }^{45}$ William Petrie, a long serving colonial doctor summed up the feelings of the colonial staff in Nyasaland:

"since we have been Federated with the other two Rhodesias, the Nyasaland MOs (who are in the Colonial Service) have felt that we are not wanted - while the Rhodesians think that the Colonials don't want to join in Federation. Unfortunately our chap at the head in Salisbury [Morris] has no interest in his M.Os as men and so there has been a steady drift away from Nyasaland of doctors who do not want to work under Federation. We have been given until 1959 to make our minds up. By that time I think there will be very few Colonials left. The

\footnotetext{
${ }^{45}$ Dr. W. Petrie to his mother, June 16, 1957. Petrie Papers, NLS.
} 
old friendly days have gone as far as our Dept. is concerned. The Federal salaries are to be less than what the Colonial ones were and no passage allowance home. The choice if you Federate is that Rhodesia becomes your home! So these are the reasons why we are so short staffed. The new chaps coming out are very inexperienced... In many ways I wish I was coming home earlier." ${ }^{, 46}$

This observation highlights a number of grievances that medical officers harbored while working for the federal service. It underscores the extent to which Nyasaland doctors felt marginalized and undervalued by a Health Ministry situated far away in Salisbury. In addition, it criticizes the senior management of the federal service for failing to foster a sense of esprit de corps within the service. ${ }^{47}$ Lastly it illustrates the extent to which doctors thought they were being underpaid. A perceived lack of competitiveness in federal terms and conditions was a major cause of the ongoing staff shortages.

Amongst the most senior staff, the major grievances were the loss of autonomy and the over centralization of the service as well as its bureaucratic nature. The Directors of Medicine reported to Morris, the Secretary of Health, in Salisbury and were required to seek his approval for any expenditure or decision. This resulted in delays and effectively rendered the directors powerless. It also probably contributed to the unusually high turnover in the Director of Medicine post in Nyasaland during the first few years of the Federation. The DMS of Nyasaland at the start of federation had been in charge of medical services in Nyasaland since 1949. By the end of 1955, he had gone, as had his deputy (and the DMS of Northern Rhodesia). Nyasaland had no less than four directors

\footnotetext{
${ }^{46}$ Dr. W. Petrie to his mother, October 7, 1956. Petrie Papers, NLS. Emphasis in the original.

47 This was also a common complaint amongst medical officers in Northern Rhodesia. The Zambezi Branch of the British Medical Association, Memorandum, March, 181960 in Report-Appendix VIII, Evidence, Volume II, Northern Rhodesia, (London: HM Stationary Office, 1960), 129-130.
} 
between 1955 and $1957 .{ }^{48}$ One only stayed three months having done an about turn in his opinion of the Ministry. Having been strongly in favor of officers of the colonial service transferring to the federal service, he resigned declaring that he would rather have a "bullet in his back than continue to work under Salisbury's dictation." ${ }^{, 49}$ It was not until Sheffield, a transfer from Northern Rhodesia, halfway through 1956, that some stability returned to the medical leadership in Nyasaland. It is ironic that Petrie viewed Sheffield as very much a Rhodesian in the same mold as federal employees from Southern Rhodesia, despite the latter's long service history in Northern Rhodesia. Petrie appears to have had a difficult working relationship with Sheffield, which, along with a growing disenchantment with the idea of federation, contributed to his decision to quit the service at end of 1957. Petrie came to believe that "“"Federation" means - "all things to be done as in Southern Rhodesia" and his letters catalogue a number of instances where Petrie believed that the director was both over authoritative and unfair in his dealings with African staff. ${ }^{50}$ On one occasion, after objecting to the sacking of fifteen workmen, Sheffield told Petrie, “If you can't carry out my orders, you may hand in your resignation." 51

Replacements for departing doctors were federal employees. Some did not want to be in Nyasaland. They complained that they had been assured during the recruitment process at Rhodesia House in London that they would be posted to Southern Rhodesia.

48 The Federation of Rhodesia and Nyasaland, Annual Reports on Public Health, 19551957 (BOA), 31.

${ }^{49}$ Dr. W. Petrie to his mother, July 15, 1956. Petrie Papers, NLS. Emphasis in the original.

50 Dr. W. Petrie to his mother, February 24, 1956. See also letters dated March 2, July 21 1957. Petrie Papers, NLS.

${ }^{51}$ Dr. W. Petrie to his mother, July 7, 1956. Petrie Papers, NLS. 
These newcomers often did not stay long and Petrie suggested that the false promise made by Rhodesia House was a deliberate and desperate ploy by the Federation to recruit doctors. ${ }^{52}$ Rhodesia House may have thought that Southern Rhodesia was a more attractive prospect to an incoming doctor given its comparatively sophisticated medical facilities, better opportunities for career advancement, and the larger European population that promised the benefit of private practice. Furthermore, the larger and more numerous towns in Southern Rhodesia meant that doctors were more likely to be posted in an urban area than in the more rural Northern Rhodesia or Nyasaland.

In the case of Southern Rhodesia, there is evidence that government medical practitioners believed that the federal Ministry of Health privileged expenditure on health in Nyasaland and Northern Rhodesia over what they saw as necessary development in the south. There is also a suggestion that some Southern Rhodesian doctors looked down on their medical colleagues in the north and the health service that the territorial services in Nyasaland and Northern Rhodesia had provided. One medical superintendent declared:

"Those braggarts in Nyasaland and Northern Rhodesia are always dancing around their puny little hospitals singing proud songs about what great medical benefits they are bringing the Natives. No one seems to realize that we spen[t] more on the Native Hospital at Bulawayo in one year than the government of Nyasaland spen[t] on all their medical services for both white and black [before Federation].

The failure to foster a medical community within the medical professionals of Federal Health Service was both a cause of and a consequence of the chronic shortage of doctors. Indeed, the lack of esprit de corps alluded to, may, in part, have been a result of

${ }^{52}$ See for example: Dr. W. Petrie to his mother, May 15, 1955 and June 11, 1955. Petrie Papers, NLS. Emphasis in the original.

${ }^{53}$ Peter B. Martin to Walter S. Rogers, October 14, 1953, Peter B. Martin Newsletters, Institute of Current World Affairs, https://www.icwa.org/peter-b-martin-newsletters/. 
the federal service's inability to keep its medical personnel, creating conditions that further undermined any idea of community. Demoralized by the rapid turnover in staff and by a policy of recruiting inexperienced replacements for those who left, many government medical officers simply decided it was better to leave the service altogether.

African medical staff had varied reasons for discontent with their federal employers. For some, particularly in Nyasaland, it was part of a deeply held antipathy towards the Federation. African nationalists in the colony continued their resistance to the Federation after it had become a reality. Medical workers participated in widespread riots and demonstrations in many parts of the colony throughout $1953 .{ }^{54}$ By June 1958, the total number of medical employees in Nyasaland had dropped from 1241 in 1953 to less than 600 , a loss of fifty percent. The vast majority of these were medical auxiliaries. Many African medical staff considered the European doctors recruited by the federal service to be tainted by a white supremacist ideology. Austin Mkandawire, a medical assistant in Nyasaland during the Federation, referred to the federal period as one of "racial suspicion and tension." ${ }^{, 55}$ In one incident, a white male nurse discovered two students in possession of aspirin and band-aids. White police officers consequently arrested twenty-five trainee medical assistants on suspicion of petty theft and conducted a complete search of the students' accomodation. Five students were sentenced to between three and five years imprisonment with hard labor. ${ }^{56}$ Mkandawire also recalled the racist attitude of federally recruited doctors towards him and his African colleagues as well as

${ }^{54}$ Mkandawire, Living My Destiny, 128.

55 Ibid., 139.

56 Ibid. 
towards the African patients. ${ }^{57}$ In his opinion, the new doctors had been "brainwashed" into believing Africans were inferior. One new recruit regularly called Africans "the scum of the earth." ${ }^{58}$ Furthermore, Mkandawire said that European staff refused to let medical aides perform tasks that they were trained to carry out, eroding their responsibilities and that they were refused "simple job[s]."

Mkandawire's observations explain why so many Africans were suspicious of the racial "partnership" that federation had promised. It also underlines the extent to which Africans in Nyasaland viewed Federation as a white settler plan to dominate and subjugate the African population in Central Africa, and why so many African government employees in the colony participated in a widespread walkout from the federal service in 1959. It is important, however, not to attribute all grievances to the growing nationalist movement and anti-federation sentiment. Grievances with matters of pay and working conditions also played a part, even if some of these were entangled with negativity towards the Federation.

Soon after the Federation was established, an Interim Federal Public Service Commission had established a European pensionable branch of the Federal Civil Service while leaving existing arrangements for African employees in place. It was thought that in the short term it would be too disruptive to standardize Africans' conditions of service

\footnotetext{
${ }^{57}$ It is notable that colonial doctors who had been part of the territorial service prior to Federation appeared to be immune to accusations of racism given the pervasiveness of discrimination and the contemporary attitudes of many colonial Europeans to Africans at this time. Mkandawire writes about an incident prior to the Federal era, in which he was the recipient of the casual violence that often marked interactions between Europeans and Africans. However, Mkandawire still valorizes his attacker for his humane treatment of Africans. Mkandawire, Living My Destiny, 85, 140.

58 Ibid.

${ }^{59}$ Mkandawire, Living My Destiny, 85, 140.
} 
and so African employees retained their territorial terms ${ }^{60}$ However, the creation of a European branch implied that it was closed to non-Europeans and hence was a violation of Article 40(2) of the federal constitution:

"No person domiciled "within the Federation who is a subject of Her Majesty or a person under Her Majesty's protection, shall on ground of race only be ineligible for employment in the Federal Public Service, and in appointing or recommending any person for such employment, regard shall be had only to his competence, experience and suitability." ${ }^{61}$

As a consequence, the Federal Civil Service was reorganized into four branches. All Europeans were automatically placed in Branch I, while the other three branches were effectively for non-Europeans. Importantly, while the reorganization was supposed to allow Africans the opportunity to reach pay parity with Europeans, in practice, nonEuropean doctors were the only occupation to be given automatic entry into Branch I. Illustrating the persistence of a colonial discourse about the African's lack of a sense of responsibility, work ethic, and integrity, Branch II was presented as a proving ground for those Africans whose occupations would have gained them access to the top tier if they had been white. For the health department, this meant that, apart from doctors, all professionally trained African medical staff such as nurses and midwives, was placed in Branch II until such time as they had proven their ability to handle the responsibilities of

${ }^{60}$ One of the major obstacles seems to have been that African were paid less for their labor in Nyasaland and it was thought the increased rates needed to bring the protectorate into line would have a devastating impact on its economy. Advisory Commission on the Review of the Constitution of the Federation of Rhodesia and Nyasaland, Survey of Developments Since 1953: Cmmd. 1149 (London: Her Majesty's Stationary Office, 1960), 59.

61 Ibid. 
the position. This was for a period of not less than two years. ${ }^{62}$ Medical auxiliaries were placed in Branch III regardless of the differences in job functions. ${ }^{63}$

The exclusion of Africans from the top most branch of the civil service until they had "proved their worth" can be viewed as an example of the way the white elite in the Federation professed a progressive agenda while at the same time perpetuating the colonial hierarchy. At the same time it continued a colonial practice of unequal pay for equal work. Prior to the reorganization of the civil service, the very few African state registered nurses working in the health service were paid less than half of that of European nurses on the same grade. ${ }^{64}$ While reorganization purported to remove this difference, in practice, the placement of African nurses into Branch II allowed the differential in pay to remain. At the end of 1959, there were 52 African state registered nurses working in the federal service. ${ }^{65}$ Of these, only fourteen had been promoted into Branch I by the end of the following year. ${ }^{66}$

The status of medical auxiliaries was also undermined in Nyasaland in the federal period. ${ }^{67}$ Prior to federation, training for hospital assistants, the most prestigious of

62 "Promotion of African Nurses," Debates of The Federal Assembly, April 4, 1960, 234. 63 Advisory Commission on the Review of the Constitution of the Federation of Rhodesia and Nyasaland, Survey of Developments Since 1953: Cmmd. 1149, 59.

64 The starting salary for European state registered nurses was $£ 600$ per annum, while African qualified nurses starting salary was just over $£ 230$ per annum. "State Registered Nurses: Statistics and Salary Scales," Debates of The Federal Assembly, August 23, $1956,1826$.

65 The Federation of Rhodesia and Nyasaland, Annual Reports on Public Health, 1960 (BOA), 28.

66 The number of nurses in Branch II had climbed to 108 by the end of 1960 . The Federation of Rhodesia and Nyasaland, Annual Reports on Public Health, 1961 (BOA), 30 .

${ }^{67}$ I do not have evidence of similar changes in training in Northern Rhodesia or Southern Rhodesia. This reflects the disparity in availability of sources. 
auxiliary positions, was a two-year extension of that given to medical aides. Competition for places in the program was extremely competitive. Mkandawire was one of only four graduates from the medical aide course to be considered for the hospital assistant's course.$^{68}$ During the Federation, the training for hospital assistants was reduced from four years to three. ${ }^{69}$ In addition, their qualification was reduced in value. They were no longer recognized as hospital assistants. Their certification referred to them as medical assistants, a title with less status. It also did not give them the privilege to practice medicine, surgery, or midwifery, and they were no longer entitled to be registered under the Medical Practitioners and Dental Act of $1924 .{ }^{70}$ Federation partnership policies were supposed to supersede the existing racial policies that limited employment opportunities for Africans and subjected them to unequal pay and working conditions. As Mkanadwire's evidence illustrates, in practice, partnership appeared to be an empty promise.

\section{Rural Health and Missions}

The worsening relations between African staff and their federal employees created problems for a Federal Health Service whose vision also embraced the increase of rural health facilities. ${ }^{71}$ The service embarked on a program of upgrading and building of smaller health units across the Federation but faced significant difficulties in ensuring

${ }^{68}$ Mkandawire, Living My Destiny, 105.

${ }^{69}$ Ibid., 85.

${ }^{70}$ Ibid, 85-6.

${ }^{71}$ Roy Welensky, "In the Federal Assembly: Extract on Health from “"“The Break Up" Effects and Consequences on the Two Rhodesias," Central African Journal of Medicine (CAJM), 9 (1963), 296. 
that they were staffed. Questions about the lack of staff at rural medical facilities were a regular feature in the debates of the Federal Assembly. ${ }^{72}$

In Northern Rhodesia, health units often took the form of one room functioning as a dispensary, with small wards either side with perhaps three beds in each. In Nyasaland, the unit was brought into line with the design of small rural hospitals in Southern Rhodesia. U- shaped, the wards formed the wings and the outpatient and treatment rooms were in the center. A central feature of this layout was the health lecture room. ${ }^{73}$ In the late colonial period, in British Central Africa, the nascent moral order of biomedicine meshed with a medical paternalism to privilege the hospital as a site of health education. Rural hospitals functioned as conduits for disseminating the value of biomedicine but also for educating what was viewed as "the primitive groups of the population" about standards of hygiene and cleanliness. ${ }^{74}$

In Northern Rhodesia the number of rural health clinics and dispensaries increased by sixteen percent between 1954 and $1958 .^{75}$ The rate of expansion could not keep pace with demand. While rural clinics provided 950 beds, they consistently operated at more than 130 percent of capacity. ${ }^{76}$ In Nyasaland, greater urgency was given to upgrading facilities, as the absolute number of clinics did not increase substantially in the

\footnotetext{
72 "Port Herald District: Provision of Health Centres," Debates of the Federal Assembly, March 13, 1956, 2387; "Health Services: Central Province of Nyasaland, August, 21, 1956, 1706-07; The shortage of staff had also hampered Nyasaland's colonial government's plan to develop more substantial rural health units in the years leading up to Federation. Nyasaland, Report on Public Health, 1949-1952, (BOA).

${ }_{73}^{73}$ Michael Gelfand, A Proud Record, 61.

${ }^{74}$ The Morton Commission, 1960, 24.

75 The Federation of Rhodesia and Nyasaland, Annual Reports on Public Health, 1958 (BOA), appendix c.

${ }^{76}$ Morton Commission, appendix vi.
} 
same period. ${ }^{77}$ Examining the usage of rural health facilities in Nyasaland is also illuminating. According to one survey, the rural government health units in the colony operated at fifty percent of capacity. ${ }^{78}$ By comparison, the number of beds in medical missions operated at 173 percent of capacity. ${ }^{79}$ This discrepancy points to the continuing importance of missions for providing the bulk of healthcare but could also be indicative of a preference of Africans to use missions rather than government facilities. Reasons for this could include the antipathy of many Nyasaland Africans towards federation, the perceived anti-federation stance of many missions (particularly the Scottish missions), and simply because Africans were accustomed to getting their health care from the mission sector. ${ }^{80}$

The urgent need to train medical auxiliaries required health administrators to make choices about how to fill available places in training schools. There had long been a belief within colonial medical circles that training should aim for quality over quantity. Missionary doctor, J Howard Cook recommended that training should aim to produce a "few thoroughly dependable workers rather than a [larger] number of less reliable

77 In 1954 there were 102 rural health units and dispensaries. By 1958 the number was 105. Advisory Commission on the Review of the Constitution of the Federation of Rhodesia and Nyasaland, Survey of Developments Since 1953: Cmmd. 1149 (London: Her Majesty's Stationary Office, 1960), 140; The Federation of Rhodesia and Nyasaland, Annual Reports on Public Health, 1958 (BOA), appendix c.

${ }^{78}$ Ibid., 141.

${ }^{79}$ Ibid.

${ }^{80}$ Anti-federal protests and activism swept Nyasaland between 1953 and 1954. While activity lessened between 1954 and the beginning of 1958, civil disturbances surged again in the wake of the return of African Congress leader, Banda, to the colony. See Joey Power, Political Culture and Nationalism in Malawi: Building Kwacha (New York, University of Rochester, 2010). For a political history of the relationship between missions and the Federation, see John Stuart, British Missionaries and The End of Empire: East, Central, and Southern Africa, 1939-64 (Grand Rapids, Mich.: W.B. Eerdmans, 2011). 
[ones]. ${ }^{\prime 81}$ Cook also recommended that candidates should be carefully selected based on their character and that strict moral supervision was needed during the training period. ${ }^{82}$ This observation was based on long-standing stereotypical ideas about the African's weak work ethic and lack of moral character. The African, it was thought, was reluctant to take on responsibility, particularly that which came with health work. A medical superintendent in Southern Rhodesia explained to his American visitor in late 1953 that hospital trained male orderlies were sent out to the eighty-eight clinics and hospitals scattered throughout the colony but that "native boys being what they are, they require a lot of replacements. ${ }^{183}$ This view surfaced again as African qualified nurses began to enter the workforce. That some seemed to "shirk [their] responsibilities" was seen as only "to be expected" at first."

The comprehensive health service that the federal health department promised to provide could not be achieved without a substantial contribution from missions in both provision and training. As in the earlier colonial period, the federal government continued a long-standing practice of subsidizing training programs in missions using grants-in-aid. Funding from the colonial governments for mission medical work had increased in the post war period as changing imperial visions of health dictated greater attention to the

${ }^{81}$ Clement C Chesterman, "The Training and Employment of African Natives as Medical Assistants," Proceedings of the Royal Society of Medicine, 25, 7, 1075.

82 Ibid. The idea that the African needed moral supervision was one of the reasons why missions were considered best placed to train female nursing assistants. This idea persisted until well into the 1940s in Central Africa. See Linda Beer Kumwenda, "The Training of Female Medical Auxiliaries in Missionary Hospitals in Northern Rhodesia, 1928-1952," Social Sciences and Missions 16 (July 2005), 103-132.

83 Peter Bird Martin to Walter S Rogers, October 5, 1953.

${ }^{84}$ The Federation of Rhodesia and Nyasaland, Annual Reports on Public Health, 1955 (BOA), 1. 
health of colonial populations. ${ }^{85}$ The federal government increased funding for missions in 1954, increasing the maintenance grant for each bed by fifty percent, allowing many to expand services and facilities. ${ }^{86}$ Between 1953 and 1958, federal aid to missions grew by two-thirds in Southern and Northern Rhodesia and by eighty-five percent in Nyasaland reflecting the dominance of the mission sector in that colony. ${ }^{87}$ A portion of the funding available went towards the training of medical and maternity assistants and a number of missions started training schools in the $1950 \mathrm{~s} .{ }^{88}$ However, there is evidence that this generally positive picture obscures the situation with individual missions, as there is anecdotal evidence that some missions actually had funding cut at some time in the federal era. ${ }^{89}$

The money received for training represented a financial lifeline for missions who were often fiscally constrained. Chilonga mission in Northern Rhodesia for instance, received a grant of $£ 180$ to train medical assistants and pay trainees wages. Without this funding, the hospital could not have continued to function..$^{90}$ Training, too, helped with staffing issues in mission hospitals as students contributed to the provision of care.

${ }^{85}$ For more on post war imperial attitudes towards colonial possessions see Randall Packard, "Malaria Dreams: Postwar Visions of Health and Development in the Third World," Medical Anthropology 17 (1997), 279-296.

${ }^{86}$ Michael Gelfand, Godly Medicine in Zimbabwe (Harare: Mambo Press, 1988), 115.

87 The Federation of Rhodesia and Nyasaland, Annual Reports on Public Health, 1958 (BOA), 3.

${ }^{88}$ Gelfand, Godly Medicine in Zimbabwe, esp. Chapter IX.

${ }^{89}$ Chitambo Mission in Northern Rhodesia was one such mission, whose funding was cut between 1955 and 1957, creating severe financial problems for a mission almost wholly reliant of government funding. Marion Currie, Livingstone's Hospital, The Story of Chitambo (Bloomington, IN: AuthorHouse, 2011).

90 Godfrey Kabaya Kumwenda, "The Role and Conditions of Service of African Medical Auxiliaries in Catholic Mission Health Institutions In Zambia: A Case Study of Chilonga Mission Hospital in Mpika District, 1905-1973" (master's thesis, University of Zambia, 2015). 
Mission and government interests were both served by this financial arrangement, but it came at a cost of greater government intervention into the health work of missions. In order to receive enhanced funding for training, missions had to ensure there were sufficient beds and qualified staff available in their hospitals to provide an acceptable standard of training. They also had to teach to a standardized curriculum. ${ }^{91}$

The need to ensure that a mission hospital was sufficiently staffed to offer training presented a stumbling block for many missions. While some had doctors and nurses who stayed for many years providing much needed stability and continuance of service, others struggled in this regard. The geographic remoteness of some missions, length of tenure, funding, and personal circumstances could affect the degree to which medical missions enjoyed good levels of staffing. The example of the Church of Scotland missions in Northern Rhodesia illustrates some of this difficulty. The church ran three mission hospitals in the north west of the country but contributed very little to their running costs. At Chitambo, the mission only paid the salaries of one doctor and one staff nurse and the hospital was reliant on federal government grants for all other funding. The situation reached a crisis point in 1959 and a choice had to be made to either cut the numbers of beds or to introduce user fees. The latter option was contentious because the local population had built Chitambo hospital under the promise of free health care in return for their labor. However, faced with the prospect of closing the hospital, it was decided to introduce a small fee. The decision resulted in a backlash from local people who boycotted the hospital, and from the federal government who already viewed the Scottish

91 A standard curriculum for training was in use in Northern Rhodesia by 1958. The Federation of Rhodesia and Nyasaland, Annual Reports on Public Health, 1958 (BOA), 25 . 
missions with suspicion because of their alleged support for African nationalism. ${ }^{92}$ In addition to the funding issue, Chitambo mission had ongoing difficulties in providing the requisite numbers of staff needed to secure government recognition of its training school. This recognition was important to secure vital government funding. In order to qualify, mission hospitals with between 70 and 80 beds were required to have one doctor and three nursing sisters. ${ }^{93}$ Again, in 1959, the prospect of yet another doctor resigning from Chitambo mission endangered the government funding. In the end some skillful negotiations with the medical department secured the recognition of training contingent on another nursing sister being found. ${ }^{94}$

By the end of 1958, there was a deep divide between the Federal Health Service's celebratory narrative of success and the realities of health service provision. The Federal Health Service was close to breaking point. Relations between African staff and their European supervisors in Nyasaland had deteriorated to the extent that one medical aide declared that anyone "who saw the fine work of the medical service 10 to 20 yrs ago would be shocked to see the present state of affairs of it and would probably refuse to rejoin it even for a thousand dollars a month." ${ }^{.95}$ The department lacked support from both

\footnotetext{
${ }^{92}$ The issue of user fees emerged on a number of occasions during the Federation period. On principle, the Federal Health Service did not want to bring in user fees because it prided itself on being a national health service providing universal access for health. However, the small tax base of the Federation meant that funding the service was an ongoing issue. It should also be noted that while the service was free for Africans and all government employees, most of the European population paid. Currie, Livingstone's Hospital, The Story of Chitambo, 123-124.

93 Currie, Livingstone's Hospital, The Story of Chitambo, 122.

${ }^{94}$ Currie, Livingstone's Hospital, The Story of Chitambo, 124.

${ }^{95}$ Medical assistant to Dr. Petrie, November 27, 1958. Petrie Papers, NLS.
} 
within and without the service. Internally, the deep divisions and widespread dissatisfaction caused a rapid turnover in staff and contributed to an ongoing shortage of medical expertise. To critics outside the service it represented a failure of federation itself.

The fortunes of the Federation were also fading. Economic depression between 1956 and 1958 led to a decreasing confidence in the prospects for the developing nation. Politically, too, 1958 was a turning point. African nationalists widely condemned changes to the federal constitution that threatened African representation in the federal government. In Southern Rhodesia, the ousting from power of the supposedly proAfrican Garfield Todd by right wing political factions together with the emergence of the Reconstituted African Congress galvanized African nationalists in the colony. ${ }^{96}$ In Nyasaland, African nationalism resurged with the return of Hastings Banda to Nyasaland.$^{97}$ The colonial governments of Northern Rhodesia and Southern Rhodesia also proposed changes to the composition of their legislative councils that seemingly further entrenched white minority power. Furthermore, Welensky, premier of the federal government, was increasingly vocal about demands for dominion status for the Federation. ${ }^{98}$ The scene was set, therefore for political turbulence in the years to come.

${ }^{96}$ West, The Rise of an African Middle Class, 212-214.

${ }^{97}$ Power, Building Kwacha, 7.

${ }^{98}$ Robert Rotberg, Rise of Nationalism, The Rise of Nationalism in Central Africa: The Making of Malawi and Zambia (Cambridge, Mass., Harvard University Press, 1965), 292. 


\section{Chapter Four.}

\section{The Struggle to Maintain a Colonial Medical Order, 1959 - 1963}

Writing on the impending retirement of the First federal Secretary of Health at the end of 1958, the Central African Journal of Medicine, opined:

"[Morris] leaves a fine medical service, one of the best in the colonial empire fully up to strength, and one for which this country has much reason to be grateful. Southern Rhodesia especially is noted for its good race relations between the white and black sections of its population and in our opinion no other department has done as much as his with its doctors and nurses to bring about this happy state of affairs."

The events of 1959 and onwards would shatter this illusion. As the Federation plunged into political chaos and lurched towards dissolution, the Federal Health Service found it increasingly difficult to fulfill its obligations. What had long been a chronic condition of understaffing became an acute crisis as many expatriate and African staff left the service and recruitment significantly slowed.

Furthermore, the health service came under attack from many quarters. Elite Africans and European critics of federation called attention to the failings of the health department and increasingly pointed to issues of access to health care and health professions as a means of exposing the contradictions and hypocrisies of federation. Critics used the Federal Assembly and two important commissions into federal functions as platforms for airing their grievances. The 1959 Morton Commission was a wide-

1 "The Approaching Retirement of Dr. R. M. Morris, The Federal Secretary of Health," CAJM, 4, 4 (1958), 172. Emphasis mine. This quote also underscores the extent to which commentators in Southern Rhodesia viewed the Federal Health Service as essentially Southern Rhodesian. As noted in chapter two, officials at the Colonial Office argued that the proposals for Federating health seemed to suggest the process represented an absorption of the Northern territorial services into Southern Rhodesia's rather than the creation of a federal service. 
ranging investigation into the functioning of the government health service. The Monckton Commission of 1960 was a comprehensive commentary on the Federation as a political unit but one in which matters of health emerged as a central issue.

Under siege, the federal government responded to criticism of its health service by launching vigorous recruitment campaigns and introducing structural changes designed to make employment in the service more attractive. Crucially, these responses were generally aimed at attracting more expatriate professionals rather than building a base of African expertise. Despite the rhetoric of partnership and the stated intention of expanding training and providing career opportunities for Africans, the response is best understood as a desire to maintain colonial medical hierarchies and perpetuate the settler colonial order.

\section{The Crisis of Staffing}

The acute crisis in staffing erupted in the middle of 1959. Two primary factors contributed to its timing; the expiry of the temporary transfer of territorial staff to the Federal Health Service at the end of June and the political turmoil generated by a surge in African nationalist activism from the start of the year.

In January 1959, the leaders of the African Congress parties in Northern Rhodesia and Nyasaland, Kenneth Kaunda and Hastings Kamuzu Banda, returned from the Accra All-African People's Conference invigorated and motivated to escalate the struggle for self-government and constitutional reform. Time was short. A comprehensive review of the Federation and its constitution was scheduled for 1960 and African nationalists feared that the British government would yield to federal demands for dominion status, resulting 
in the "perpetual subjugation" of Africans to the white settler regime. ${ }^{2}$ During the first two months of the year, tension rose in the colonies as Kaunda and Banda launched verbally aggressive attacks on the Federation and its supporters. Neither leader explicitly endorsed the use of violence to achieve their aims. Nevertheless, the protests and demonstrations, which were part of the ensuing campaigns of civil unrest carried an underlying threat of force. ${ }^{3}$

The intensity of the nationalist campaigns invoked a robust response from the colonial and federal governments. In Northern Rhodesia, the Zambian African National Congress was banned and its leader, Kaunda, imprisoned. In Nyasaland, the governor, with federal backing, prepared a crackdown on the Malawi Congress party based on the understanding that Congress was "bent on pursuing a course of violence, intimidation, and disregard of lawful authority." ${ }^{, 4}$ In Southern Rhodesia, the government banned the Reconstituted Congress Party, declared a state of emergency, and mobilized federal troops to support the Nyasaland government. ${ }^{5}$ On March $3^{\text {rd }}$, the Nyasaland governor declared a state of emergency. In the aftermath of the declaration, colonial military and police forces detained more than 1300 people. Fifty-one lost their lives and a further seventy-nine suffered gunshot injuries in action that was reminiscent of the British response to Mau Mau uprisings in Kenya. ${ }^{6}$

The governor of Nyasaland later asserted that he had declared a state of emergency based on intelligence that a plot existed to murder all Europeans if Banda was

\footnotetext{
${ }^{2}$ Quoted in Rotberg, The Rise of Nationalism, 293.

${ }^{3}$ Rotberg, The Rise of Nationalism, 294-5.

${ }^{4}$ Quoted in Rotberg, The Rise of Nationalism, 298.

${ }^{5}$ Murphy, British Documents, lxxii.

${ }^{6}$ Murphy, British Documents, lxxiii.
} 
arrested. According to an informer for Special Branch, on a designated day, "R-day," between ten and twenty-four days after Banda's arrest, a coordinated uprising of sustained violence including the murder of women and children would sweep the colony. According to the Special Branch Report:

"Each District Chairman was responsible for murdering his own DC or where there was a PC, the PC and his staff first, followed by the Police Officer and then any other European. In the township areas there was to be widespread murder of Europeans and Asians. H.B. Chipembere said the murders were to include all women and children. Their bodies were to be mutilated and then burned if possible."

The Devlin Commission, appointed by the British government to investigate the emergency was extremely critical of the colonial government's handling of the situation. It referred to the colony as a police state and concluded that there was little credible evidence to suggest that "R-day" referred to a timed murder plot. ${ }^{8}$ As the Devlin report noted and oral sources later confirmed, "R-day" actually marked the ending of the arrangement by which government employees had been temporarily transferred to the federal civil service. " "R-day," on June $30^{\text {th }}$, was the last day for medical staff to elect to make their temporary transfer permanent. Those who did not wish to do so had to resign on, or before that date. ${ }^{10}$

Large numbers of African and expatriate medical workers resigned from the federal health department on "R-day," turning what was a chronic shortage of staff into a

${ }^{7}$ Qtd in Power, Building Kwacha, 138.

8 Philip Murphy, "A Police State? The Nyasaland Emergency and Colonial Intelligence," Journal of Southern African Studies, 36, 4 (2010), 765.

${ }^{9}$ The Devlin Report pointed to a federal government circular produced in April 1958, detailing the transfer arrangements and suggesting that the date be referred to as "R-day." "Nyasaland Commission of Enquiry, $17^{\text {th }}$ July 1959, TNA CAB 129/98, 85-86; Power, Building Kwacha, 138-9.

${ }^{10}$ Nyasaland Commission of Enquiry, $17^{\text {th }}$ July 1959, TNA CAB 129/98, 85-86. 
crisis that threatened to cripple the service. The effect of "R-day" was the opposite of what the newly appointed Secretary for Health, Dyson Blair, had expected. Blair thought that the end of the temporary transfer arrangement would help to build a unified medical community saying, "Finally, all the staff of all races will have one loyalty to the federal service." ${ }^{11}$ Blair appears to have seriously miscalculated the extent to which neither expatriate nor African staff wished to be part of the service.

The crisis in staffing did not occur without warning. In Nyasaland, less than half of African medical workers had transferred to the service in 1953. By the end of 1956, only thirty-eight percent of expatriate medical officers in the Federation had accepted federal terms. Most were stationed in Southern Rhodesia. Only twenty-two percent of officers in Northern Rhodesia and none of those in Nyasaland had transferred. A full onethird had left the service altogether. There were warnings that if this pattern was repeated in 1959 , at the end of the transfer period, "the already serious staff situation ... will become catastrophic." 12 The question is why didn't the health department address the problem earlier, either by offering better terms, stepping up recruitment, or changing the conditions of employment to make the federal service more attractive? As the years rolled by, it appears that it was easier to blame the ongoing issue on the press coverage maligning the Federation outside of the country than to take remedial action.

${ }^{11}$ The Federation of Rhodesia and Nyasaland, Annual Reports on Public Health, 1958 (BOA), 1.

12 The Federation of Rhodesia and Nyasaland, Annual Reports on Public Health, 1956 (BOA), 1. 
It seems many European members of staff resigned because they were unsure about committing to a long-term future in Central Africa. ${ }^{13}$ It is also true that they could take advantage of favorable compensation terms if they chose to resign rather than transfer permanently to the federal service. ${ }^{14}$ In total, forty-eight expatriate doctors resigned on "R-day," leaving fourteen percent of professional staff posts unfilled. ${ }^{15}$ In the professional nursing service, "R-day" resignations further exacerbated shortages due to the number of nurses who left the service to get married. For example, in Northern Rhodesia, fifty-nine qualified nurses resigned during 1959, representing a quarter of the permanent, professional nursing workforce. Of these, thirty-eight got married and a further fourteen resigned on "R-day." 16 The health service continued to function but the loss of so much professional medical expertise was significant.

Senior federal health officials asserted that medical auxiliaries in Nyasaland and Northern Rhodesia decided to resign on "R-day" because they had been unduly influenced by the inflammatory political rhetoric of African nationalists. In Blair's opinion, the decision had been a hasty one, based on naive and unformed political

${ }^{13}$ The Federation of Rhodesia and Nyasaland, Annual Reports on Public Health, 1959 (BOA), 1.

14 "Abolition of office" terms were negotiated between the incoming federal government and the colonial office back in 1953. This agreement determined that when the territorial health services was transferred to the Federal Service on July 1 1954, all posts in the territorial service had effectively been abolished and no longer existed. Thus for those officers who did not wish to make their transfer permanent could elect to retire on an enhanced pension or receive a financial compensation. The commissioners of the Morton report believed that this more than anything was a major cause of the many resignations of European staff in 1959. TNA CO/1015/1090: Buchanan, "Observations on the Process of Federating the Medical and Health Services of Rhodesia and Nyasaland," January 5, 1953.

${ }^{15}$ Morton Commission, 7-8.

16 The Federation of Rhodesia and Nyasaland, Annual Reports on Public Health, 1959 (BOA), 27. 
motives. ${ }^{17}$ However, there is evidence that African medical workers anticipated the prospect of a significant walk out on "R-day" many months in advance of the event. In November 1958, the Nyasaland Auxiliary Medical Organization (NAMO), decided to bring forward the date of its annual meeting to March or April of 1959 because its board members thought that "R- day" could result in many African auxiliaries walking off the job. ${ }^{18}$ This illustrates that motives for the "R-day" action were at least in part due to grievances and concerns relating to working conditions within the federal service. However, the walkouts should also be seen as part of an ongoing campaign of civil disturbance aimed to disrupt the activities of the federal government.

Walkouts on "R-day" in Nyasaland among African medical workers were widespread. In Cholo, thirty miles from Blantyre in the Southern Province, fifty percent resigned while in Karonga in the Northern Province, two out of three medical assistants and fifteen out of seventeen medical aides left. In the latter case, it took three months for attendance at the hospital to recover as rumors circulated that the federal government had replaced the staff with unskilled laborers. ${ }^{19}$ The Ministry of Health attempted to minimize the extent of the "R-Day" action, asserting service had been disrupted at only "one or two" rural health units. Attendance at government units in Nyasaland in 1959 dropped by twenty-five percent, amounting to more than one million fewer visits. The health

\footnotetext{
17 Ibid., 1.

18 Medical Assistant to Dr William Petrie, 27 November 1958, Petrie Papers, NLS. 19 The Federation of Rhodesia and Nyasaland, Annual Reports on Public Health, 1959 (BOA), 20-21. Karonga was long a hot bed of Malawian nationalism. Medical workers in the province left their jobs in protest when Health was federated and devoted their time to political activism for the Malawi National Congress. Owen J. M. Kalinga, "The 1959 Nyasaland State of Emergency in Old Karonga District," Journal Of Southern African Studies 36, 4 (2010), 743-763.
} 
department attributed the drop to people's fear of leaving their homes during the riots and disturbances during the year but it is also possible that non-attendance at government health facilities was also an expression of anti-federal sentiment. By comparison, attendances at mission facilities in Nyasaland increased by twelve percent over the previous year, around 168,000 more visits. ${ }^{20}$ Furthermore, at least one rural hospital stopped admitting patients because security forces took over the ward accommodation during the emergency. ${ }^{21}$ Larger urban hospitals were also affected. Many medical employees walked out at the flagship Queen Elizabeth hospital in Blantyre, after being promised re-employment when Nyasaland gained its independence. ${ }^{22}$

The crisis in staffing reverberated through the following years of federation. At the end of 1960, one-third of all medical posts were vacant. As a result, the health service was forced to rely on the goodwill of retired doctors returning to work. ${ }^{23}$ In the nursing service, some 250 posts were vacant and a further 355 nurses were employed on temporary contracts. The staffing shortages also exacerbated the inequity of health provision between urban centers and rural areas. In 1961, there were only three European health inspectors for the whole of Nyasaland and shortages of medical auxiliaries

\footnotetext{
${ }^{20}$ Attendances at government facilities and missions during 1958 were 4,211,379 and $1,381,855$ respectively. The corresponding figures for 1959 were 3,151,537 and 1,549,709. The Federation of Rhodesia and Nyasaland, Annual Reports on Public Health, 1958 (BOA), 15. The Federation of Rhodesia and Nyasaland, Annual Reports on Public Health, 1959 (BOA), 19.

${ }^{21}$ The Federation of Rhodesia and Nyasaland, Annual Reports on Public Health, 1959 (BOA), 14.

${ }^{22}$ Interview with Ceciwa Bwanausi Khonje, cited in Power, Building Kwacha, 269 fn. 16.

${ }^{23}$ The Federation of Rhodesia and Nyasaland, Annual Reports on Public Health, 1960 (BOA), 1.
} 
persisted following the "R-day" walkouts. Consequently, work at rural leprosy treatment centers was severely curtailed. $^{24}$

Stretched to almost breaking point, senior officials at the Ministry of Health drew up plans for concentrating health provision at fewer centers. It cut services and closed some medical facilities in rural areas in each region, prioritizing continuity of service in urban areas. ${ }^{25}$ However, the situation also threatened healthcare delivery in major urban hospitals. In Southern Rhodesia, branches of the British Medical Association stepped in to organize a casualty roster at the central hospitals in Salisbury and Bulawayo. The colony was more fortunate than its northern neighbors in this regard, having a large number of private medical practitioners who were prepared to step into the breach. ${ }^{26}$

The continued fallout from the "R-day" resignations increased pressure on a health service already heavily dependent on its African auxiliary staff. ${ }^{27}$ African auxiliaries comprised more than seventy percent of the Health Ministry's employees. ${ }^{28}$ By 1960 there were ninety-six rural hospitals and 254 rural health clinics in the Federation, many staffed by auxiliaries working, for the most part, unaided. ${ }^{29}$ In addition the shortage of medical officers meant visits to rural hospitals became much more

24 “Antileprosy Activities in Nyasaland," International Journal of Leprosy, 29, 3 (1961), 368.

25 The Federation of Rhodesia and Nyasaland, Annual Reports on Public Health, 1960 (BOA), 1.

26 Ibid., 3.

27 I do not have evidence of how widespread similar action was in Northern Rhodesia but Blair's comment in the 1959 annual report is suggestive that a similar situation occurred in the colony. The Federation of Rhodesia and Nyasaland, Annual Reports on Public Health, 1959 (BOA), 1.

28 The Federation of Rhodesia and Nyasaland, Annual Reports on Public Health, 1960 (BOA), 38.

${ }^{29}$ Ibid. 
infrequent increasing the autonomy of the medical assistants in charge. ${ }^{30}$ In urban areas, too, medical assistants took on more responsibility as unfilled vacancies and generous leave entitlements meant that even larger hospitals struggled to maintain a sufficient medical and nursing establishment. ${ }^{31}$

The increased reliance on African auxiliaries placed a greater burden on training schools in Nyasaland and Northern Rhodesia to graduate adequate numbers of medical aides, nursing orderlies, and other auxiliary staff. However, in the wake of the emergencies and amid increasingly strident African resistance to the Federation, the federal health department experienced greater difficulty in attracting sufficient students or achieving a satisfactory graduation rate. In Nyasaland, for example, all second and third year nursing orderly trainees who were supposed to be completing midwifery training were dismissed, supposedly due to political agitation that had fostered unacceptable insubordination among the students. ${ }^{32}$

The issue of student graduation was most pressing at the government training schools in Northern Rhodesia. The government operated two medical assistant training programs. At the women-only school in Livingstone, thirty-two percent of trainees abandoned their training in 1959 and another twenty-three percent in 1960. At the Lusaka men-only school, an average of twenty-five percent of students left the training program in each of the years between 1959 and 1962. Less than fifty students in total completed

\footnotetext{
30 Ibid.

31 Ibid.

32 Letter to Dr William Petrie, 27 November 1958, Petrie Papers, NLS. The annual Federal health report for 1959 confirmed that the dismissal of this entire class was because of political insubordination. The Federation of Rhodesia and Nyasaland, Annual Reports on Public Health, 1959 (BOA), 28.
} 
the medical assistant courses at the two schools in those years. ${ }^{33}$ The poor rate of completion caused Blair, to lament that the future "looks bleak" for a rural medical service dependent on its medical assistants. ${ }^{34}$

The Lusaka school, in particular, had difficulty in attracting and retaining men in its program. In 1960, out of 190 male students accepted for auxiliary training in Northern Rhodesia, only thirty-six entered the Lusaka school. The federal Ministry of Health attributed this to the targeting of the school by political agitators, something that illustrated the "immaturity of perpetrators of agitation and dissension" who maliciously influenced a student body "undergoing training for a vocation of vital importance to the health of African people." ${ }^{35}$ As Frederick Cooper has observed, this formulation speaks to British ideas that politically, Africans were viewed as either "primitives or demagogues, the latter threatening to mobilize the inchoate grievances of the former" rather than having political views of their own or legitimate grievances. ${ }^{36}$ By some accounts, conditions at the Lusaka training school were bad. In 1961, An African federal Member of Parliament drew attention to the poor food and substandard accommodation for trainees in the school. The somewhat off hand response from the federal Minister of Health was that standards at the government school were probably better than at many

33 The figures in this paragraph are drawn from: The Federation of Rhodesia and Nyasaland, Annual Reports on Public Health, 1959-1962 (BOA).

34 The Federation of Rhodesia and Nyasaland, Annual Reports on Public Health, 1960 (BOA), 30.

35 The Federation of Rhodesia and Nyasaland, Annual Reports on Public Health, 1961 (BOA), 33.

${ }^{36}$ Frederick Cooper, Decolonization and African Society: The Labor Question in French and British Africa (Cambridge: Cambridge University Press, 1996), 18. 
training schools in Southern Rhodesia. ${ }^{37}$ The unsatisfactory conditions may have been why forty students at the school went on strike in 1962. All were dismissed from the training program. ${ }^{38}$ Yet, the idea of federation had been extremely unpopular with much of the African population in Northern Rhodesia well before it became a political reality and their antipathy only increased during its existence. This is evidenced by the marked increase in rumors of Banyama, vampire men who allegedly kidnapped Africans, drained their blood or extracted their brains transforming them into zombies. ${ }^{39}$ Accusations of Banyama were leveled at Europeans and Africans who supported federation through membership of the liberal, multiracial, elite, Capricorn Society or whose work was closely associated with the federal government. ${ }^{40}$ Is it possible that Banyama as a form of political intimidation deterred men from enrollment in federal training programs and caused students to abandon their courses?

\section{Commissions and Critiques}

The extreme staffing difficulties within the Federal Health Service emerged at a time when the federal government was bracing itself for the anticipated review of its constitution. When the Federation was established, the constitution made provision for a Federal Review Conference within seven to nine years to consider any changes deemed

\footnotetext{
37 "Lusaka African Medical School," Debates of the Federal Assembly, August 9, 1961, 1560.

${ }^{38}$ The Federation of Rhodesia and Nyasaland, Annual Reports on Public Health, 1962 (BOA), 36.

${ }^{39}$ James A Pritchett, Friends for Life, Friends for Death: Cohorts and Consciousness among the Lunda-Ndembu (Charlottesville, VA, University of Virginia Press, 2007) 129. ${ }^{40}$ Luise White, Speaking With Vampires: Rumor and History in Colonial Africa (Berkeley, Ca, University of California Press, 2000), 302-303.
} 
necessary. ${ }^{41}$ Ahead of the conference, the British government appointed an advisory commission, led by Walter Monckton, to advise the Federal Review Conference on the Federation's future form. ${ }^{42}$ The commission, carried out over the first six months of 1960, was a wide-ranging investigation into every aspect of federation. The British government assured the Federation's Prime Minister, Roy Welensky, that the commission did not have the authority to recommend that any territory could secede from the Federation and that the commission could only recommend changes to the Federation's constitution. ${ }^{43}$ African nationalists objected to the commission's limited terms of reference, arguing that they made it nothing more than a sham. ${ }^{44}$ In Nyasaland, the Malawi Congress Party urged for a complete boycott of the commission, a measure largely successful, particularly in the Northern Province. ${ }^{45}$

The commission was a commentary on the Federation as a political unit but one in which health emerged as a major issue. The authors of the subsequent report were to state that the provision of health was the cause of much political controversy and that no other

\footnotetext{
41 Advisory Commission on the Review of the Constitution of the Federation of Rhodesia and Nyasaland Report: Cmmd. 1148, Northern Rhodesia (London: HM Stationary Office, 1960), 6.

42 Ibid.

43 Philip Murphy has shown that Harold Macmillan privately gave Lord Shawcross permission to consider all solutions to the Federation's problems including the right to secede. The apparent duplicity made Macmillan an enemy of the white settlers in Southern Rhodesia. Philip Murphy, "Introduction," in British Documents on the End of Empire: Central Africa, Part I: Closer Association 1945-1958, edited by Phillip Murphy (London: The Stationary Office, 2005), 1xxviii.

44 Power, Building Kwacha, 147.

45 Ibid., 243, fn 74.
} 
federal function provided a greater volume of evidence. ${ }^{46}$ This was particularly true of evidence collected from Northern Rhodesia. There, Africans, who gave evidence, vilified the Federal Health Service accusing it of inadequate funding, discriminating against African employees, and causing standards of service to fall. One witness's evidence encapsulated many Africans' perspective saying:

"the Federal Ministry of Health...has proved a failure...the African hospitals are in a disgraceful state, the standard of service has dropped; the surroundings are very dirty, the Government (Federal) trucks which in the rural areas were doing the work in place of the Ambulance no longer do that...there is no money ...for cutting grass 100 yards from the hospital...for replacement of old, old blankets...better plates, for proper cooking of food.... for better uniforms...for building better Isolation wards, what is the use of saying Federal Services are good if the good things cannot be seen? Are we to rely upon what we hear, and not what we see?",47

Here, the witness exposed the tendency of the federal government to loudly proclaim the excellence of its health service and the benefit it had brought to the African people. This trend was part of a widespread federal campaign at home and abroad designed to legitimize the Federation and white settler rule. Within the Federation, pro-federal newspapers and newssheets such as The African Eagle and FACT often carried stories of how the federal government had provided excellent health services and career opportunities for African people in what can be considered a battle for the hearts and minds of a skeptical and rebellious African population. ${ }^{48}$ Overseas, the "Voice and

\footnotetext{
${ }^{46}$ Advisory Commission on the Review of the Constitution of the Federation of Rhodesia and Nyasaland Report: Cmmd. 1148, Northern Rhodesia, (London: HM Stationary Office, 1960), para 136.

47 Ibid.

${ }^{48}$ See for example: "Modern African Hospital to Replace Present Small Buildings," The African Eagle, June 16, 1959; "Expansion of Health Services," The African Eagle, March 3, 1959; "Federal Health Service Offers Good Careers," FACT, 1, 5 (Aug. 1960), Welensky Papers, Box 269; "Better Health For All," FACT, 1, 2 (May 1960), Welensky Papers, Box 269. Jennifer Johnson has explored the utility of health service provision in
} 
Vision" public relations campaign projected an image of the Federation as a fast developing, progressive nation that had brought significant benefits to the standard of living of African people. Andrew Cohen has argued that it is likely that the campaign advertisements proclaiming the educational and health benefits that the Federation had brought to Africans were a preemptive rebuttal to the findings of the Monckton Commission. The large-scale advertisement illustrating the work of the Federal Health Service that appeared in the London Times one day before the official publication of the Monckton report supports this assertion. ${ }^{49}$

The need to counter the negative dimensions of the Monckton report was important to the federal government for a number of reasons. First, a negative report risked damaging the increasingly fragile image of the federal government as one invested in the concept of multiracialism and committed to safeguarding the welfare of African people. Second, by 1960, the public image of colonialism, empire, and settler states was increasingly negative. This was due to the wide international press coverage of brutal colonial repression in places such as Kenya, Nyasaland, and South Africa. Third, there was a growing awareness that the surging tide of African nationalism on the continent was unstoppable and that independent African nation-states were the future. The Federation appeared to be increasingly anachronistic, a political formulation out of step with current ideas.

garnering support for a nationalist movement. See Jennifer Johnson, The Battle for Algeria: Sovereignty, Health Care, and Humanitarianism (Philadelphia, University of Pennsylvania Press, 2016).

${ }^{49}$ Andrew Cohen, "Voice and Vision" - The Federation of Rhodesia and Nyasaland's Public Relations Campaign in Britain: 1960-1963," Historia, 54, 2 (2009), 118. 
Reviewing the evidence to the Monckton Commission suggests that the beleaguered federal government and its health service attempted to limit employee participation in the evidence hearings. Even though the federal department was one of the largest employers of educated, literate Africans in the Federation, I have found no submissions from African medical workers. In case of Nyasaland, this may have been due to the Malawi Congress Party boycott of the commission. However, it may also have been that African medical staff simply did not receive information about how to submit evidence to the commission from the government in time. A doctor in Nyasaland said that he had only received pamphlets about this after the deadline for applying to give evidence had passed. ${ }^{50}$ Furthermore, there is evidence that the Federal Health Service refused to allow government medical officers from appearing in the commission hearings. A letter from the office of the Director of Medical Services in Northern Rhodesia stated that a government medical officer could only give evidence in an individual capacity and only when invited to do so. They were not permitted to give evidence as representatives of either the Federal Health Service or in any other capacity such as membership of the local BMA. ${ }^{51}$

The report from the Monckton Commission advocated returning health to the territories. Supporters of federated health viewed the findings of the Monckton Report as flawed and based on "a cursory examination of the position" illustrating "muddled and

50 Dr. D. Stevenson, UCMA, Fort Johnston, February 5, 1960 in Report-Appendix VIII, Evidence, Volume III, Nyasaland, (London: HM Stationary Office, 1960), 151.

51 Annexure to oral evidence, B, Letter from R. Park (for DMS) to Dr. Oliver, March 17, 1960 in Report - Appendix VIII, Evidence, Volume II, Northern Rhodesia, (London: HM Stationary Office, 1960), 131. 
uninformed thinking. ${ }^{, 52}$ They derided the commission's recommendations, arguing that political considerations had trumped technical ones. ${ }^{53}$

On the question of the Federation and its future, the Monckton commission reported that the political union was deeply flawed. It recommended that Northern Rhodesia should follow Nyasaland in enacting constitutional reform to permit elections for the Legislative Council. ${ }^{54}$ Crucially, the commission appeared to step outside its terms of reference in recommending that any of the three territories should, in theory, be allowed to secede. Roy Welensky called the resultant report, "the death knell of Federation. ${ }^{.55}$

The Monckton Commission's recommendation to return health to the territories was in stark contrast to a second commission that reported its findings in the same year. The Morton Commission was tasked with performing a general review of the functions and administration of the Federal Health Service. The commission toured the Federation visiting major towns and hospitals. In doing so, the commission heard evidence from fifty interested organizations and sixty individuals, of which a good number were nurses,

52 "The Monckton Commission and Health," CAJM, 6, 11 (1960), 496.

${ }^{53}$ See for example, R.M. Morris, "Health and the Monckton Commission Report," CAJM, 6,11 (1960), 496-499; "Health Services In The Federation Of Rhodesia And Nyasaland," The British Medical Journal 2, 5207 (1960), 1213-214.

${ }^{54}$ In 1960, changes to the constitution in Nyasaland paved the way for elections for seats on the Legislative Council to occur for the first time in 1961. The Malawi Congress Party led by Banda won every seat it contested. The election confirmed the MCP as the dominant African party and set a course for the colony's independence. Tom Lodge, Denis Kadima, and David Pottie, "Malawi," in Compendium of elections in Southern Africa, edited by Tom Lodge et al. (Johannesburg: Electoral Institute of Southern Africa, 2002), 121-122.

55 "Collapsing Bastion," Time 76, 17 (October 24, 1960): 43, Academic Search Premier, EBSCOhost (accessed March 19, 2017). 
government medical officers, and private practitioners. ${ }^{56}$ It did not interview any African medical workers and did not visit any rural health facilities.

In their final report the commissioners endorsed the decision to federate health. However, they were critical of many aspects of the Federal Health Service. The report called attention to "the difficulties of the first five formative years of centralized Federal control [that] have almost inevitably caused a certain amount of disturbance, misunderstanding and discontent." ${ }^{57}$ In addition, it noted witnesses' "complaints of delays ... in overcoming shortages in the medical, nursing' and domestic staffing of hospitals, all of which, it was claimed, could have been either avoided or lessened if local experience and resources had been properly used. ${ }^{, 58}$ Furthermore, the report criticized the Ministry of Health of being a "centralized and impersonal administration" that had applied "broad national policies blindly" without regard for local conditions. ${ }^{59}$

The Morton Commission's accusation of over-centralization, excessive bureaucracy, and lack of consideration for local needs and concerns resonated with much of the evidence submitted to the Monckton Commission. African and European witnesses to the latter pointed to the difficulties of working with the health service's central administration. Complaints included the constant shortage of drugs due to the length of time it took to procure replacements and the amount of paperwork required before

\footnotetext{
56 Morton Commission, vii.

57 Ibid., 26.

58 Ibid.

${ }^{59}$ Ibid.
} 
receiving approval for any health project. ${ }^{60}$ Missions complained that promised grant-inaid money was not always forthcoming and that federal officials always took the credit for having facilitated the opening of new clinics or hospitals even when missions had provided the majority of the funding and local Africans, the labor. ${ }^{61}$ Furthermore, local authorities complained that it was difficult to get permission to build new health facilities. ${ }^{62}$ This was a shift from earlier in the federal period when the participation of African local authorities in adding much needed health infrastructure was warmly welcomed. ${ }^{63}$ By the 1960s, the Health Ministry was complaining that this practice interfered with the planned development of health infrastructure and created problems for the federal department, which was expected to staff and finance the clinics. ${ }^{64}$ The African response was that the federal department was out of touch with what health infrastructure was needed on the ground because they were too far away in Salisbury. ${ }^{65}$ This shift in federal policy reflects the growing inability of the Federal Health Service to provide adequate medical manpower for its services in the later federal period. It is also indicative

60 Zambezi Branch of the British Medical Association, written evidence, March 18, 1960 in Report-Appendix VIII, Evidence, Volume II, Northern Rhodesia (London: HM Stationary Office, 1960), 129.

61 J.E. Parry, written evidence, March 5, 1960 in Report - Appendix VIII, Evidence, Volume I, Northern Rhodesia, (London: HM Stationary Office, 1960), 204.

62 Soli Native Authority, oral evidence, March 171960 in Report-Appendix VIII, Evidence, Volume II, Northern Rhodesia (London: HM Stationary Office, 1960), 94. 63 The Federation of Rhodesia and Nyasaland, Annual Reports on Public Health, 1957 (BOA).

64 The Federation of Rhodesia and Nyasaland, Annual Reports on Public Health, 1960 (BOA).

65 Dr. Musk MO, Chitambo Mission, Memorandum, February 29, 1960, 176, S. M. Mununga, MLC Luapula District, Memorandum, March 3, 1960 in Report-Appendix VIII, Evidence, Volume II, Northern Rhodesia (London: HM Stationary Office, 1960), 194. 
of an increasingly defensive federal health department, which perhaps viewed the local authorities' building of health infrastructure as a critique of its operations.

Predictably, supporters of the Federal Health Service welcomed the Morton Report because of its support for federating health in spite of its criticisms of the service. This was probably because, despite recommending sweeping changes to recruitment, service conditions, and policy, the report couched its advice within a familiar colonial framework. Solutions to the shortage predicament centered, for the most part, on continuing a policy of attracting expatriate expertise from Britain or other white settler dominated parts of the Commonwealth. While the commission recognized the utility of the African medical worker, it asserted the continued need for European supervision. Furthermore, its vision of the hospital as a center of medical research and site of education of a people, which they believed had only recently been lifted out of savagery resonated with an essentially paternalistic colonial administration. ${ }^{66}$

The publication of the Morton Report sparked a lively debate in the Federal Assembly. As a major function of the federal government, matters pertaining to the policies and practices of the health service were a regular feature of assembly debates. The parliamentary discourse on the health service shifted over time. In the early years of federation, a major concern was the inadequate and substandard medical facilities, especially in Northern Rhodesia. This included questions about the completion dates of new clinics or extensions of existing infrastructure, complaints about overcrowding in African hospitals, and calling attention to the dilapidated condition of many existing hospitals and clinics. In the later federal period, as more qualified African nurses and

${ }^{66}$ Morton Commission, 24. 
doctors began working in the Federation's hospitals, questions about staffing and opportunities for Africans to further their careers became more prevalent.

The African members in the Federal Assembly were adept at exposing the hypocrisy of "partnership." When the Health Minister blamed African nationalist activism for obstructing recruitment of qualified staff from outside the Federation, African members would ask why more African doctors and nurses were not recruited from South Africa or why professional nurse training had not been started in either Nyasaland or Northern Rhodesia. ${ }^{67}$ Speaking in the debate on the Morton Report, Mr. Chembe, African member for Northern Rhodesia, launched a scathing attack on the federal Ministry of Health. Chembe deplored the policy that insisted a South African black nurse had to be married to a Federation national to be eligible for employment, pointing out that white expatriate nurses were not subject to the same restriction. ${ }^{68}$ Chembe also questioned the practice that required African nurses to resign from the service when they became pregnant and lost all their years of service when they returned to work. ${ }^{69}$ Chembe pointed out that the South African service gave their nurses maternity leave, encouraging the nurse back into the workplace. ${ }^{70}$ Furthermore, Chembe complained that the practice of insisting student nurses were single created problems

67 "African Nursing Sisters: Training Facilities in Nyasaland," Debates of The Federal Assembly, August 30, 1961, 1749-50.

68 "Consideration of the Report of Commission of Inquiry into Health and Medical Services," Debates of The Federal Assembly, April 13, 1960, 757.

${ }^{69}$ Clement Masakure informed me that all the African nurses working in the 1960s that he interviewed for his dissertation raised the point about having to resign from the service and reapply from scratch if they wanted to return after having children. Clement Masakure, email communication with author, Feb 6, 2017; Consideration of the Report of Commission of Inquiry into Health and Medical Services," Debates of The Federal Assembly, April 13, 1960, 758.

${ }^{70}$ Ibid., 758. 
when the nurses worked within an African community that conferred greater status and respect to married women. ${ }^{71}$ Crucially, Chembe linked his complaints to the federal government's stated policy of multiracial partnership, saying,

"are we following partnership when African doctors from other countries are not accepted... and when highly trained nurses are not accepted in this country... There are educated people from the Union of South Africa and you will not admit them here. And if an African doctor who is trained in the Union of South Africa comes here he is chased away from Harari hospital and sent to a rural hospital. That is the policy of this government and yet you talk about partnership.,"72

\section{The Quest for Medical Personnel}

The federal government and Ministry of Health made several changes in response to the crisis in staffing and the recommendations of the Morton Commission. The health department launched a vigorous recruitment campaign, improved conditions of service and pay, and introduced legislation that expanded recruitment beyond the Federation's traditional recruiting grounds of Britain and countries of the Commonwealth. It is significant that the Ministry of Health responded in ways that enhanced recruitment of medical professionals from overseas. By doing so, the health department gave greater weight to those recommendations from the Morton Commission that perpetuated the service's dependency on expatriate expertise and demonstrated a white settler determination to maintain the colonial medical hierarchy and settler colonial order. Advice from the Morton Commission that did not fit within this framework was disregarded. The decisions about which recommendations the health department chose to implement exposes the inflexibility of the medical elite in seeking a solution to the

\footnotetext{
${ }^{71}$ Ibid.

72 Ibid., 757.
} 
staffing crisis and illustrates that there were limits to the level of African participation that the ruling settler elite was prepared to accept.

The Ministry of Health improved conditions of service and rates of pay for its medical officers. The service increased a doctor's base pay and prohibited government medical officers from private practice, paying a special allowance as compensation for loss of potential revenue. The Ministry viewed the payment as having a double benefit. It further raised salary levels, making the Federal Health Service more competitive in the global marketplace. It also appeased the powerful lobby of private practitioners in Southern Rhodesia, who strongly resented the government medical officers' ability to draw a government salary, enjoy generous leave and pension entitlements, and carry out private practice for personal gain. ${ }^{73}$ The service also created a new position for Junior Resident Medical Officers. This aimed to attract newly qualified doctors looking to fulfill their junior residency requirement, which entailed a year long paid internship in a hospital setting. The federal health department hoped to entice graduates from British medical schools by offering to cover the cost of travel to and from the Federation. ${ }^{74}$

The federal government also enacted legislative changes effectively widening the recruitment net for the health service. The legislation permitted doctors from other countries to register in the Federation as long as they demonstrated a working knowledge of the English language. It appears to have been fairly successful as eleven doctors with

${ }^{73}$ The Federation of Rhodesia and Nyasaland, Annual Reports on Public Health, 1962 (BOA), 1.

${ }^{74}$ Junior Resident Medical Officers are those who have received their medical degree but need to obtain a year's hospital experience as part of their final qualification as a medical doctor. The hospital has to be recognized by the institution conferring the degree in order for the experience to be valid. "Consideration of the Report of Commission of Inquiry into Health and Medical Services," Debates of The Federal Assembly, April 4 1960, 246. 
"foreign" degrees accepted employment by the end of 1961 with another twenty in $1962 .^{75}$

Legislation and structural changes aside, the primary response of the health department was a vigorous campaign to recruit expatriate qualified medical personnel from Britain. This included a recruitment tour by the Secretary for Health, advertisements in professional journals, and use of the Central African Film Unit to make a film aimed at attracting medical personnel to the Federation.

The Secretary for Health, Blair, spent three months in 1960 in Britain on a recruiting mission for medical staff. The tour had limited success and recruitment of sufficient staff remained elusive. It was the view of the Minister for Health (one that Blair shared) that the negative publicity in the overseas press about the Federation made it very difficult to attract staff and this, rather than pay and conditions of service was the primary reason for recruitment difficulties. There is evidence that this view may have had at least some validity. In the wake of the state of emergency declaration in Nyasaland, for example, five of six doctors recruited in Britain for the Federation cancelled their passages. ${ }^{76}$ A member of the federal parliament responded by saying that "it was ... a very great pity that some of [the doctors] were so chicken-hearted" to allow a small disturbance blown out of proportion by the overseas press to deter them and that perhaps

75 "First Foreign Doctor for Health Service," Rhodesia and Nyasaland Newsletter, December 6, 1961, AD1715, Various memos and correspondence on African Welfare Societies in Southern Rhodesia, constitutional affairs and race relations 1953-1964, 27.3.22, SAIRR, 6 .

76 "Consideration of the Report of Commission of Inquiry into Health and Medical Services," Debates of the Federal Assembly, April 4 1960, 245. 
they "were not the type we wanted anyway and we are just as well without them.,"77 Officials at the Ministry of Health also asserted that the federal government was unfairly blamed for staffing shortages and that potential recruits were deterred by rumors that the federal service was to be broken up. ${ }^{78}$

In early 1962, the Federal Health Service contracted the Central African Film Unit, to shoot a film aimed at attracting medical doctors and nurses to Central Africa. ${ }^{79}$ Shown in medical and nursing schools, at British Medical Association meetings, and to enquirers at Rhodesia House in London, the film, Invitation to Adventure, promised a medical career that would appeal to a pioneering spirit. However, it also reassured the viewer that practicing medicine in the Federation would be similar to that in Britain but better because of the superior climate, wide open spaces, and benefits of lifestyle on offer. The Federation was portrayed as a country with good communications, and a thriving capital city, Salisbury. The narrator asserted that there was "no place on earth where as a medical practitioner you can make such an important contribution to building a health service. ${ }^{, 80}$ Applicants were encouraged to join the social experiment of the Central African Federation and help build a great nation. ${ }^{81}$

Invitation to Adventure showed what a doctor working in a rural area could expect on a typical day. In discussing some of the medical issues the applicant might encounter, the film stressed that an important part of the work was combating "ignorance." Issues

\footnotetext{
77 Ibid., 252.

78 Ibid., 246.

79 "An Invitation to Adventure" (Southern Rhodesia: Central African Film Unit, 1962), VHS (20 min), British Film Institute, London, Colonial Film: Moving Images of Empire, viewed September 2016.

80 Ibid.

81 Ibid.
} 
such as malnutrition, for example, were not due to neglect of public health or of poverty but a result of the ignorance of the African. ${ }^{82}$ What was striking about the film was that Africans were largely absent, appearing only as patients or, briefly, as (male) medical aides. A large part of the film was devoted to selling a white settler way of life to prospective candidates. The Federation was depicted as a white man's country, "a land of great natural beauty but also of progress and a vitality that is stimulating." The film emphasized the professional links to Britain and ended with an "invitation to you to join us in a great adventure to put medicine to work to create a full and happy life for all our people and the generations to come." ${ }^{\circledR 83}$

An Invitation to Adventure targeted a certain type of medical practitioner, an expatriate professional who was European, preferably British or at least Commonwealth trained. Furthermore, the expatriate doctors that the service hoped to attract were white and male. The Southern Rhodesian settler elite, of which doctors were very much a part, desired a new national identity that would bind together all whites and embraced a masculinity that was a "muscular one...laughing-in-the-face-of- danger, at-ease-in-thebundu (wilderness), and at-ease-with-the-natives." ${ }^{" 84}$ An Invitation to Adventure aimed to attract doctors who had the same pioneering spirit that Southern Rhodesian white medical professionals believed characterized the early doctors who made the colony their home in the first decades of the twentieth century. Such thinking also illustrates the persistence of an ideology that saw white, male doctors at the apex of a gendered and racialized colonial

82 Ibid.

83 Ibid.

${ }^{84}$ Marc Epprecht, "Black skin, 'cowboy' masculinity: a genealogy of homophobia in the African nationalist movement in Zimbabwe to 1983," Culture, Health \& Sexuality, 7, 3 (May, 2005), 256. 
medical hierarchy and also a desire on the part of the medical elite to maintain the image of biomedicine as a practice performed, for the most part, by white practitioners. ${ }^{85}$

The exception to this construction was the realization that the only way to provide health care effectively in African rural areas was to employ African medical practitioners. This represented a shift from an earlier period in which it was thought that African medical assistants would be the primary providers of care in rural clinics and even small hospitals but always with regular visits and inspections by a white medical doctor. In part, this shift was an acknowledgement of the impossibility of staffing remote rural hospitals with white professional staff but it also reflected the reality of a small, growing cadre of federal African qualified doctors.

The first African doctors to work in the Federal Health Service were generally mission educated and completed their medical studies at either the University of Witwatersrand or the University of Natal in South Africa. Returning to the Federation, they often completed their intern year at the Harari hospital before becoming a government medical officer. The first of these, Dr. Tichafa Samuel Parirenyatwa, remained at Harari hospital as a General Medical Officer after his intern year. Not all members of staff at the hospital received his appointment favorably, "a number were critical and a few were openly hostile." ${ }^{" 86}$ Parirenyatwa was soon transferred "in the interests of race relations" to a rural posting sixty miles south of Bulawayo. Ironically, Parirenyatwa was responsible for providing medical care for black and white patients at the rural Antelope Mine Hospital because he was the only doctor for sixty miles. White

\footnotetext{
85 Warwick Anderson, "How's the Empire: An Essay Review," Journal of the History of Medicine and Allied Sciences, 58,4 (2003), 464. 86 "Obituary," CAJM, 8, 9 (1962), 356-358.
} 
farmers were initially horrified at the idea of being treated by a black doctor. However, by the time Parirenyatwa left after two years, to go into private practice and devote more time to nationalist politics, he had become very popular with African and European patients ${ }^{87}$ While more research is needed to trace the careers of these early African doctors, it does appear that at least some were posted to rural areas after completing their year's internship. Dr. Mcleod Chitiyo, who would become the first African pathologist in Southern Rhodesia, was posted to a remote medical station in Nyasaland. ${ }^{88}$ A rural posting enabled the federal service to man remote medical stations and also circumvented the issue of white nursing sisters serving under black doctors. ${ }^{89}$

\section{Continuing Crisis in the Nursing Service}

The "R-day," exodus of expatriate nursing expertise and subsequent difficulties in recruitment turned what had long been a chronic shortage of qualified nurses within the federal service into a crisis. To be sure, the chronic shortage was the partly a consequence of colonial neglect to provide advanced nurse training to Africans but it was also exacerbated by the long-standing policy that required women to leave the service when they got married. ${ }^{90}$ This policy conformed to prevailing social norms about gender.

87 Judith Garfield Todd, Through the Darkness: A Life in Zimbabwe (Cape Town, SA: Zebra Press, 2007), 222-223.

${ }^{88}$ Dr. David Parirenyatwa, "Chitiyo leaves indelible imprint on medical scene," The Herald (Zimbabwe), 2 Mar. 2016, accessed Mar. 10 2017, https://www.pressreader.com/ ${ }^{89}$ Shula Marks has noted that in South Africa, the prospect of black doctors instructing white nurses filled many white nurses with greater horror than the prospect of nursing black bodies. It represented "a profound inversion and subversion of natural racial hierarchies in which all whites, regardless of class or gender, were superior to all blacks." Shula Marks, Divided Sisterhood, 140.

${ }^{90}$ Masakure, "One of the most serious problems confronting us at present," 119-120. 
A married woman's place was in the home and her primary function was to raise children. The extent to which this was normative is illustrated in the Morton Commission's discussion of the problems within the nursing service. The commission said that "a large scale breakdown in the [Federal] nursing service... threatened" due to ill-formed policies regarding promotion, inflexible conditions of service, and substandard nurses accommodation..$^{91}$ The commission did not mention the policy dictating resignation on marriage and gave no advice about how the service might address the problem of large numbers of student nurses finishing their training but leaving soon after to get married. By 1959, only thirty-two of 203 European nurses that had been trained by the department since the start of federation remained in the Federal Nursing Service. ${ }^{92}$

In response to the Morton Commission's report, the Ministry of Health introduced a one-year contract scheme specifically aimed at attracting white professional nurses from Britain. Advertisements in British nursing journals urged nurses to "come and nurse in the sunshine for 12 months. Friends can travel together." ${ }^{93}$ The health service paid the recruit's passage both ways and it was hoped that, once in the Federation, some would either extend their contracts or join the permanent staff. ${ }^{94}$ The plan was fairly successful and a year later 127 "sunshine girls," as they were known, were in service in government hospitals throughout the Federation. Of the initial group of twenty-seven

91 Morton Commission, 63.

92 The Federation of Rhodesia and Nyasaland, Annual Reports on Public Health, 1959 (BOA), 27.

93 Sally Hubbard, "Nursing in Zomba, 1963-1964," in An Expatriate Experience of Life and Work in Nyasaland, edited by Colin Baker, vol. 3 (Cardiff: Mbemba Books, 2014), 303-312.

94 The Federation of Rhodesia and Nyasaland, Annual Reports on Public Health, 1962 (BOA), 31. 
who arrived in March of 1962, ten extended their contracts, one joined the Federal Nursing Service, one left to nurse in South Africa, and four resigned on marriage. ${ }^{95}$ While the one-year contract plan brought more nurses into the service, it barely scratched the surface of the shortage in nursing expertise. As previously noted, 250 nursing posts were vacant at the end of 1960. Two years later, the figure was almost as high meaning that the nursing service remained twenty percent understaffed. The shortages were evenly spread across the three territories. However, in Southern Rhodesia, the shortfall was somewhat cushioned by 588 student nurses who were at various stages of the state registered training program. ${ }^{96}$ Hence the crisis in nurse staffing disproportionately affected the northern territories of the Federation and illustrates how decisions about the placement of state registered nursing programs can be seen as evidence of the marginalization of the northern colonies.

The adoption of the "sunshine girls" contract scheme further illustrated the reliance of the nursing service on temporary staff. Perpetually short of nurses, the federal service had already become heavily dependent on a pool of temporary nursing labor made available by the policy dictating that nurses resign on marriage. These nurses returned to work for periods varying between a few weeks to several years. ${ }^{97}$ Relying on a largely temporary workforce created difficulties in planning and posting nursing expertise where it was most needed. Indeed, the Morton Commission highlighted that

\footnotetext{
95 ““'Sunshine Girls” Still Coming,” CAJM, 9, 1 (1963), 33. 96301 of these were African, 255 European, and 32 Asian or "Coloured."The Federation of Rhodesia and Nyasaland, Annual Reports on Public Health, 1962 (BOA), 31. 97 Ibid., 1.
} 
many European hospitals appeared to be relatively overstaffed, as the following table illustrates:

\begin{tabular}{lccccc}
\hline & $\begin{array}{c}\text { In-Patient } \\
\text { Daily Average }\end{array}$ & $\begin{array}{c}\text { No. of } \\
\text { Beds }\end{array}$ & $\begin{array}{c}\text { European State } \\
\text { Registered Nurses }\end{array}$ & $\begin{array}{c}\text { Occupancy } \\
\text { Percent. }\end{array}$ & $\begin{array}{c}\text { No of Patients } \\
\text { per Nurse } \\
\text { (Daily } \\
\text { Average) }\end{array}$ \\
\hline Rusape & 6 & 12 & 10 & 50 & 0.6 \\
Marandellas & 4 & 8 & 7 & 50 & 0.6 \\
Choma & 5 & 13 & 6 & 41 & 0.8 \\
Selukwe & 4 & 14 & 7 & 33 & 0.6 \\
Gwanda & 2 & 17 & 6 & 30 & 0.3 \\
Mazabuka & 4 & 14 & 7 & 28 & 0.6 \\
Enkledoorn & 4 & 17 & 7 & 26 & 0.6 \\
Filabusi & 2 & 12 & 5 & 18 & 0.4 \\
\hline
\end{tabular}

Table 1: Staffing: European Government Hospitals, Central African Federation, $1959^{98}$

In contrast, a table with the same data for African hospitals within the same district illustrates the extent to which they were over crowded and understaffed by comparison:

\begin{tabular}{lccccc}
\hline & $\begin{array}{c}\text { In-Patient } \\
\text { Daily Average }\end{array}$ & $\begin{array}{c}\text { No. of } \\
\text { Beds }\end{array}$ & $\begin{array}{c}\text { African } \\
\text { Nurses (SRN and } \\
\text { auxiliary) }\end{array}$ & $\begin{array}{c}\text { Occupancy } \\
\text { Percent. }\end{array}$ & $\begin{array}{c}\text { No of Patients } \\
\text { per Nurse } \\
\text { (Daily } \\
\text { Average) }\end{array}$ \\
\hline Rusape & 198 & 160 & 27 & 124 & 7.3 \\
Marandellas & 120 & 97 & 14 & 124 & 8.5 \\
Choma & 122 & 186 & 30 & 65 & 4.1 \\
Selukwe & 62 & 24 & 6 & 258 & 10.3 \\
Gwanda & 149 & 116 & 16 & 129 & 9.3 \\
Mazabuka & 61 & 75 & 21 & 82 & 2.9 \\
Enkledoorn & 109 & 54 & 14 & 202 & 7.8 \\
Filabusi & 136 & 120 & 10 & 113 & 13.6 \\
\hline
\end{tabular}

Table 2: Staffing: African Government Hospitals, Central African Federation, $1959^{99}$

What is striking about the data in each of these tables is that despite the African and European hospitals being situated within the same district, there does not seem to have

${ }_{98}$ Morton Commission, 16-17.

${ }^{9}$ Ibid., The Federation of Rhodesia and Nyasaland, Annual Reports on Public Health, 1959 (BOA). 
been any reallocation of nursing capacity to even the nursing workload. Excess European nurses do not appear to have been posted to the African hospitals even where the number of patients per African nurses was relatively high and the European nurses had very few patients. Indeed, it seems that in some European hospitals, patients received care on a one-to-one basis.

The second table shows that a number of the African staff were state registered nurses. The first professionally trained African nurses were those who had trained in South Africa. From 1962, state registered African nurses trained at federal hospitals entered the workforce. As far I can discern, the new nurses were solely employed at African-only hospitals or on the African wards of multiracial hospitals. Some support for this is evident in the Minister for Health's statement that no qualified African nurses worked in European hospitals because they were "fully employed" in caring for African patients. ${ }^{100}$ The training and employment of African state registered nurses permitted the maintenance and extension of a segregationist policy that was a cornerstone of health care practices in the earlier colonial era and persisted into the federation period despite its progressive rhetoric of multiracial hospitals and partnership.

Senior health officials in the Federation saw as desirable a separate but somewhat equal health service in which Europeans provided care in European hospitals and Africans, always under European supervision, care in African hospitals. However, the senior medical community never intended to decolonize the health service. They never envisaged an African Secretary of Health, for instance, or an African Medical

100 "Government Hospitals: Staff," Debates of The Federal Assembly, August 9, 1961, 640. 
Superintendent of the Salisbury group of hospitals. Accordingly, the pace of

Africanization of the service was exceedingly slow. In part, this was due to the late start of advanced medical training in the Federation. As we have seen state registered training of African nurses only began in 1958 and the first cohort did not enter the workforce until 1962. Training of doctors did not start in the region until 1963, the very end of the federal period. But the slow pace was also because the federal health department appeared to cling to the belief that that solutions to the staffing crisis lay in recruiting medical expertise from overseas.

The emphasis on the use of temporary expatriate staff illustrates the unwillingness of the Ministry of Health to consider more innovative solutions to the staffing crisis. The Morton Commission had recommended that professional nurse training be extended to men and that medical aides should be allowed to enter training to become state registered, professional nurses. ${ }^{101}$ Neither recommendation was acted on. In August of 1961, when staffing levels in the nursing service had reached a "dangerously low level," African federal MPs asked the Health Minister if he would consider accepting African women for training who were currently working as trained medical aides. ${ }^{102}$ Medical aides training programs required less schooling as a condition of entry but the aides would have received two or threes years of medical training, were literate in English, and had a number of years of hospital experience. Furthermore, the African MPs noted that nursing schools within Britain accepted some medical aides from the Federation into their state

\footnotetext{
101 Morton Commission, 24.

102 The Federation of Rhodesia and Nyasaland, Annual Reports on Public Health, 1961 (BOA), 29; "Training of African Nurses," Debates of The Federal Assembly, August 7 1961, 514-515.
} 
registered training programs. ${ }^{103}$ Why, the African MPs queried, did the federal health department not do the same? To do so would help provide a long-term sustainable solution to the staffing issue while also providing a career path for medical aides perhaps encouraging more girls who did not have sufficient schooling for advanced nurse training to consider entering medical aide programs. The Health Minister's response was that under no circumstances would the standards of entry into the state registered programs be dropped because to do so would merely increase the number of student nurses who failed to pass their examinations. ${ }^{104}$ The minister's refusal to consider the proposal to train medical aides exposes the inflexibility of the Ministry of Health in the way it addressed the staffing crisis but it also reflected a belief common among federalists that the Federation could only be a success through the hard work of qualified men and women. ${ }^{105}$ The emphasis on standards and qualifications enabled white settlers to maintain the colonial medical hierarchy and the settler colonial order while appearing to adopt the progressive language of partnership and development.

\footnotetext{
103 There was an acute staffing crisis within the NHS in the early 1960s, which may have contributed to the willingness of training programs to consider applicants with working experience even if they did not have the formal education qualifications: Stephanie Snow and Emma Jones, "Immigration and the National Health Service: putting history to the forefront," Policy Papers, History and Policy, March 8, 2011, viewed 23 March, 2017, http://www.historyandpolicy.org/policy-papers/papers/ 104 "Training of African Nurses," Debates of The Federal Assembly, August 7, 1961, 514-515. ${ }^{105}$ Luise White makes the point that federalists became adept at talking about minority rule without invoking race. Ian Smith, leader of the Rhodesian Front, asserted that the fact that these qualified people were white was a coincidence of history. This, of course, ignores the willful neglect of colonial governments to educate the African population. Luise White, Unpopular Sovereignty: Rhodesian Independence and African Decolonization (Chicago: University of Chicago Press, 2015), 32. Emphasis mine.
} 
The staffing situation, at least regarding the number of doctors, did improve by the end of 1962. Increases in pay and enhanced career paths for junior doctors combined to make the federal medical service more competitive in the global market for medical practitioners. Blair asserted that the improvement was also due to the growing reputation of federal hospitals as places "where the young medical graduate can gain a wide and varied experience under the direction of expert specialist staff in excellent surroundings."106 These changes disproportionately benefited Southern Rhodesia. The number of junior medical doctors in the colony tripled without a corresponding increase in Northern Rhodesia and Nyasaland. At the end of 1962, ninety-five percent of general medical officer posts in Southern Rhodesia were occupied. In Northern Rhodesia and Nyasaland nearly a quarter of posts remained vacant. ${ }^{107}$

During the last years of the Federation, the white settler elite led by Roy Welensky, fought a rearguard action to salvage the political union while African leaders in Northern Rhodesia and Nyasaland made substantial progress towards gaining independence. African opposition to the Federation in the northern territories was well organized and the Malawi Congress and United National Independence Party had widespread support. Banda and Kaunda were released from detention and participated in negotiations with the British and colonial governments on constitutional reform.

By 1962, Dr. Hastings Banda was the de facto prime minister of Nyasaland and under his leadership, the Nyasaland Legislative Council initiated policies designed to

106 The Federation of Rhodesia and Nyasaland, Annual Reports on Public Health, 1962 (BOA), 1.

107 Ibid., 29. 
illustrate that independence would benefit the African population. ${ }^{108}$ The policies included expansion of secondary education and the abolition of the thangata system. ${ }^{109}$ Thangata was a system of labor rent that required agricultural tenants to work for estate owners for two months a year, often at times when the tenants' own farms required attention. While the council could not enact any policies pertaining to health care, it was able to disrupt the Federal Health Service by refusing to allow federal officers access to schools for vaccination programs. ${ }^{110}$ Nyasaland became a self-governing territory in early 1963. In Northern Rhodesia, the path to self-government was slower, hindered by a lack of progress on constitutional reform. However, elections towards the end of 1962 allowed Kaunda and his party, the United International Party for Independence, to form a government. ${ }^{111}$

In March of 1963, the British government confirmed the right of any territory in the Federation to secede signaling the inevitability of the Federation's demise. For the Ministry of Health, the complicated business of unraveling the Federal Health Service had begun.

\footnotetext{
108 Rotberg, The Rise of Nationalism in Central Africa, 312-313.

109 As John McCracken has shown, Banda did not actually abolish Thangata through legislative means but introduced policies backed by the British Colonial Office that led to the ending of a practice that had long been hated. John McCracken, A History of Malawi, 392-393. Brian Morris, An Environmental History of Southern Malawi: Land and People of the Shire Highlands (Cham: Springer International Publishing, 2016), 159.

110 The Federation of Rhodesia and Nyasaland, Annual Reports on Public Health, 1961 (BOA), 16.

${ }^{111}$ Roberts, A History of Zambia, 220-221.
} 


\section{Epilogue}

\section{Endings and Beginnings}

At the end of 1963, the outgoing Secretary for Health lamented the dissolution of the Federation and the "destruction" of its health service that put an end to ten years of "high endeavour by thousands of devoted and capable officers." 1 It is ironic that the Federal Health Service was dissolved at a time when senior health officials considered that the Ministry was finally making good on its original aims and objectives. 1962 had been a year of growth. Over 900 patient beds had been added and staffing levels had somewhat improved, at least in Southern Rhodesia. Other causes for optimism were the imminent opening of the new medical school and the first cohort of state registered African nurses had completed their training. ${ }^{2}$ The dissolution of the Federation revealed the fragility of the northern branches of the Federal Health Service. Despite assertions that federating health had produced a "great health service," it had largely continued a colonial legacy that privileged healthcare for urban dwellers over rural inhabitants, Europeans over Africans, and its policies tended to marginalize the northern territories. The effect of this marginalization became evident in the early independence period when the governments of Malawi and Zambia committed to providing health services for their populations.

1 The Federation of Rhodesia and Nyasaland, Annual Reports on Public Health, 1963 (BOA), 1.

2 The Federation of Rhodesia and Nyasaland, Annual Reports on Public Health, 1962 (BOA), 1. 


\section{Dissolution}

The key issue facing negotiators on the transfer of federal functions back to the territories was the need to ensure that the territorial services had enough staff to continue functioning. To this end, an inter-government agreement was formed in early 1963. In theory, the agreement provided a pathway to a smooth transition. In practice, it continued the uncertainty and discontent so prevalent in the federal era.

Under the terms of the agreement, expatriate federal officers were invited to remain for a transitional period and those who wished to stay in Central Africa after dissolution could apply to any of the three territorial services. In May 1964, officers who had not received offers of employment from the territorial services were eligible for enhanced compensation. Any officers who had been offered employment but chose to leave anyway would only receive their pension due to them. ${ }^{3}$

According to Blair, offers of employment from the territorial governments were late in arriving meaning that officers did not know whether they had employment or not, often right up to within a few days of the scheduled transfer of services. Blair accused the respective territorial governments of complacency saying that they appeared "obsessed with the belief that federal officers would be forced by economic and other circumstances to accept whatever offer of employment was made to them." ${ }^{\prime 4}$ In his view, the governments had no appreciation of the competitive global market for medical professionals and their attitude led to many officers deciding to leave Central Africa

3 “Committee On Overseas Affairs," The British Medical Journal, 2, 5362 (1963), 135. 4 The Federation of Rhodesia and Nyasaland, Annual Reports on Public Health, 1963 (BOA), 1. 
permanently. Whether Blair's assertion is correct or not, what is clear is that the question of compensation did foster a deep sense of injustice and anger among colonial medical practitioners at the British government. In 1964, a spate of letters to the British Medical Journal from ex-federal medical officers complained that they had been let down by the British government and that they felt "expendable.,"

The doctors were unhappy with the seeming reluctance of the British government to adequately compensate colonial medical officers when independence ended their employment in the colonies. The doctors pointed to other parts of the empire such as Ghana or Nigeria where medical officers had received enhanced compensation regardless of whether they stayed in the colony or not. In the British government's view, the Federal Health Service had been a locally based one and its medical officers, therefore, locally domiciled and as such, not entitled to receive any extra money. As the principle mediator for medical practitioners, the British Medical Association (BMA) attempted to intercede. The BMA declared that the government's decision was unacceptable because the former members of the colonial medical service in Central Africa had been encouraged to join the Federal Health Service based on Britain's commitment to the Federation's continuing existence. As such, the BMA believed that the British government had a moral obligation to these doctors now that it had "blown [the

${ }^{5}$ See for example, E. Robinson, "Plight Of Doctors In Central African Federation," The British Medical Journal 1, 5388 (1964), 985. D. E. C. Mekie, "Plight Of Doctors In Central African Federation," The British Medical Journal 1, 5393 (1964), 1316. J. A. D. Bradfield, "Plight Of Doctors In Central African Federation," The British Medical Journal 1, 5391 (1964), 1186; J. L. Mason and Also Expendable, "Plight Of Doctors In The Central African Federation," The British Medical Journal 2, 5403 (1964), 249-50. 
Federation] up." ${ }^{, 6}$ Despite vigorous lobbying by the BMA, the British government remained steadfast in its decision to uphold the inter-government agreement, merely promising to set up a hardship committee, which would look into individual cases of exfederal officers who suffered financial adversity. ${ }^{7}$

\section{Post Federation - Malawi and Zambia}

The actions of the British government almost certainly contributed to the exodus of European doctors after the dissolution of federation. At the end of 1963, one in five medical professionals employed by the Federal Health Service left Central Africa, a disproportionate number of them from the Northern territories. ${ }^{8}$ Dr. John Goodall, for instance, who worked in Nyasaland, wrote that he had to find another job and that remaining, as an expatriate doctor in independent Malawi, was not an option. Goodall was able to use his connections within the colonial medical service to secure a position in the Bahamas. ${ }^{9}$

The number of medical officers in Nyasaland dropped from thirty-seven in 1958 to just fourteen. ${ }^{10}$ By May 1964 only twelve out of twenty-five general medical officer posts were filled, only one surgeon was available, and no psychiatrist. ${ }^{11}$ Only three out of

6 "Committee On Overseas Affairs," The British Medical Journal, 2, 5362 (1963), 13536.

7 “Displaced Doctors." The British Medical Journal, 1, 5379 (1964), 41-42.

8 The Federation of Rhodesia and Nyasaland, Annual Reports on Public Health, 1963 (BOA), 22.

${ }^{9}$ John Goodhall, Goodbye to Empire: A Doctor Remembers, 92.

${ }^{10}$ Baker, "Government Service in Malawi," 307.

${ }^{11}$ Availability of sources do not permit a examination of the immediate post federation medical staffing situation in Northern Rhodesia but the annual reports for 1963 and 1964 are highly suggestive of a comparable difficulty. The territorial service certainly lost its 
thirteen district hospitals had doctors. In addition the nursing service was twenty percent understaffed. ${ }^{12}$ On a more positive note, forty-four medical assistants and aides who had resigned in 1959 rather than join the federal service, were reinstated and principal medical assistants provided the bulk of care in the vast majority of district hospitals. ${ }^{13}$

The international community stepped in to help the Malawi service with personnel and much needed funding. The Israeli government provided a team of eleven doctors. Normally new recruits were dispersed to work in the district hospitals but the leader of the Israeli group explained that "they were a team and they worked together one doctor knew about heads another about feet - together they could treat all ailments." ${ }^{, 14}$ In the event, the Israeli doctors provided medical care at two of the major urban hospitals. ${ }^{15}$ Britain contributed twenty nurses, two matrons, and a senior tutor, while Canada sent a tutor and the Netherlands, one nurse. Britain and the Netherlands supplemented the salaries of the nurses they provided and Canada took on responsibility for paying the tutor.

The staffing situation in both Malawi and Zambia was further exacerbated by the lack of any facilities to train qualified nurses or doctors. For nursing, both countries were able to start training schools relatively quickly. In the case of Malawi, the British and Canadian tutors organized a state registered nurse training school in Blantyre. The school opened with twenty-three students in the summer of 1965. The Malawian Minister for

Director of Medical Services, who relocated to Southern Rhodesia and replaced Blair as Secretary of Health in 1964.

${ }_{12}$ Nyasaland, Report on Public Health, 1964 (BOA), 1.

${ }^{13}$ Baker, "Government Service in Malawi," 307; Nyasaland, Report on Public Health, 1964 (BOA), 1.

${ }^{14}$ Robbie Robbins, Extract from memoir in Colin Baker, email to author, April 82016. ${ }^{15}$ Nyasaland, Report on Public Health, 1964 (BOA), 1. 
Health remarked on the large numbers of girls leaving school who were academically qualified to enter professional nurse training. ${ }^{16}$ This is in contrast to the assertion made in the federal period regarding the possibility of a training school in Nyasaland. In Zambia, too, training of qualified nurses was underway at Kitwe by 1965, a year after independence. Medical schools were much longer in the making. In Zambia, the medical school opened in 1968. It was attached to the Lusaka hospital, which had been renamed the University Teaching Hospital. Malawi however would not start to train its own doctors until 1991.

Africanization of the health services in Malawi and Zambia proceeded much more slowly after independence compared with other British colonies such as Uganda or Nigeria. In large part this was due to the almost complete dependence on white professional staff. In Zambia, less than one hundred Africans held college degrees and less than a thousand had secondary-school certificates. ${ }^{17}$ As late as 1967 , whites occupied two out of three of the top Zambian civil service positions. In Malawi, only one African doctor worked for the government health service in 1964. Nearly two decades later, the government employed just twelve Malawian doctors. In contrast, Uganda and Nigeria had the advantage of medical schools established in the colonial period. When those countries won their independence, there was a cohort of African medical practitioners who were prepared to take over the medical services. ${ }^{18}$

\footnotetext{
16 "The National School of Nursing, Malawi," CAJM, 11,7 (1965), 271.

17 Andrew Roberts, A History of Zambia (London: Heinemann, 1976), 234.

18 John Iliffe, East African Doctors: A History of the Modern Profession (Kampala, Uganda: Fountain Publishing, 2002), 118-119.
} 
When Banda ascended to the presidency in Malawi, he was expected to promote an African medical profession, in part because he was the victim of a persistent color bar that denigrated African medical practitioners. ${ }^{19}$ However, according to John Luwanda he despised African doctors, regarding them as inferior to European expatriates. After the Cabinet Crisis in 1964, all educated Africans, including doctors, were marginalized losing much of their authority and respect. ${ }^{20}$ In 1967, the Secretary for Health and the Chief Medical Officer were both part of the colonial past having served in the colonial medical service for many years. ${ }^{21}$ Luwanada argues, that attacks on Malawian doctors' professional status initiated a brain drain of physicians that has continued into the present day. ${ }^{22}$ Luwanda further asserts that Banda and the new elite Malawians in power did not make good on promises to improve social services, including health, for the benefit of all Malawians but monopolized the scarce biomedical facilities that existed at independence. $^{23}$

In contrast to Banda's Malawi, the new government of Zambia made wider access to health (and education) a priority in the early years of independence. An important difference between the new nations was Zambia's relative economic prosperity. A vibrant world economy fueled demand for the nation's copper. Between 1963 and 1969, the

19 John Iliffe has examined the struggle for professional recognition by African doctors in East Africa. John Iliffe, East African Doctors.

${ }^{20}$ John Lwanda, "Doctoring the Brain Drain: Medical Case of Malawi," African Issues 30, 1 (2002), 48.

21 "News From Malawi," CAJM, 13, 3 (1967), 67.

${ }^{22}$ Lwanda, "Doctoring the Brain Drain: Medical Case of Malawi," 48.

23 Ibid. 
value of mineral exports rose by 163 percent, permitting the Zambian government to expand health and education programs. ${ }^{24}$

At independence, in 1964, most healthcare provision was centered in the large urban areas of Livingstone, Lusaka, and the Copperbelt. Outside of these, health infrastructure was concentrated along the railway that ran between Livingstone and the towns of the Copperbelt. Much of rural Zambia was still without health service provision or was served by one of nineteen mission hospitals. ${ }^{25}$

The Zambian government immediately increased aid to many missions. ${ }^{26}$ The staff at Chitambo hospital looked forward to the new era with cautious optimism. Relations with the federal government had been strained. Currie, the missionary doctor, wrote that the federal government appeared to regard mission hospitals as superfluous and not part of the essential medical services of the country. ${ }^{27}$ The Zambian government also altered training courses at missions. In 1965 it scrapped the medical assistants course, replacing it with one similar to that of the enrolled nursing course in existence in Britain. $^{28}$ This allowed missions to take applicants with a lower level of education. In 1966, the length of the nursing course was reduced to two years from three in an effort to train much needed medical manpower to staff the growing number of health units in the country. $^{29}$

\footnotetext{
${ }^{24}$ Marcia M. Burdette, Zambia: Between Two Worlds (Boulder, Co: Westview Press, 1988), 64.

25 Ibid.

26 Currie, Livingstone's Hospital, 162.

27 Ibid., 145.

${ }^{28}$ Ibid., 164.

${ }^{29}$ Ibid., 166.
} 
By 1972, The Zambian government had facilitated the expansion of medical missions and had taken over those mission hospitals such as Chitambo, which had run into financial difficulties despite the extra grants-in-aid. ${ }^{30}$ It had nearly doubled the number of government hospitals and rural health clinics and there were three times the number of urban clinics compared with the end of federation. ${ }^{31}$

\section{Post Federation - Southern Rhodesia}

The Southern Rhodesian territorial service did not have the same crisis in staffing as did the services in the colonies to the north. The service benefited from the relocation of staff from Northern Rhodesia and Nyasaland during 1964. In particular, a number of senior medical staff moved south. Some were Southern Rhodesians who had been deployed in the northern territories and were merely returning home, while others decided that career prospects might be more favorable in Southern Rhodesia. ${ }^{32}$ In addition, the nursing service, which would continue to suffer from serious shortages, was aided by a considerable number of student nurses, a source of nursing labor not available to either Malawi or Zambia because of the policy regarding the opening of training schools in the federal era. At the end of 1964, nearly 600 student nurses and a further 30 trainee midwives were working within the Southern Rhodesian service. ${ }^{33}$

When federation failed, the Southern Rhodesian white settlers narrowed their nation building focus onto the Southern Rhodesian state. In 1965, the ruling Rhodesian

\footnotetext{
${ }^{30}$ Marcia M. Burdette, Zambia: Between Two Worlds, 68. Marion Currie, Livingstone's Hospital, 172.

31 Ibid., 68.

${ }^{32}$ Southern Rhodesia, Report on Public Health, 1964 (BOA), 1.

${ }^{33}$ Ibid., 49.
} 
Front party headed by Ian Smith declared unilateral independence (UDI) from Britain, setting the stage for a bloody and protracted war for independence, a struggle known as the Second Chimurenga. Zimbabwe finally attained its freedom in 1980.

The two major issues facing the Southern Rhodesian service after the end of federation were a severe lack of funding and a growing isolation that began with UDI in 1965 and accelerated after the declaration of the Rhodesia republic in 1970. Funding had been difficult in the twilight of federation as first, political uncertainty and then the Federation's seemingly inevitable demise, made it increasingly difficult to attract investment. The end of federation meant that Southern Rhodesia lost significant income from copper revenue and taxes levied in Northern Rhodesia and Nyasaland. During the federal era Southern Rhodesia had received some $£ 70$ million in taxes from Northern Rhodesia. The northern territories had shouldered proportionally more of their previous expenses than Southern Rhodesia, which transferred some of its expenditure, for example, European education and agriculture, to the federal government. ${ }^{34}$ For the territorial medical service in Southern Rhodesia, the funding crisis in its first year after dissolution meant that services were cut. ${ }^{35}$ The new Secretary for Health, Dr. Webster warned that the health service must be properly funded, especially if the service wanted to attract sufficient professional staff. ${ }^{36}$

The crisis of funding endangered the future of the newly opened medical school in Salisbury. The school had opened its doors to twenty-four students in the March of 1963. However, many of the faculty buildings and a proposed 350-bed teaching hospital

\footnotetext{
${ }^{34}$ Rotberg, The Rise of Nationalism in Central Africa, 256-257.

${ }^{35}$ Southern Rhodesia, Report on Public Health, 1964 (BOA), 2. 36 Ibid.
} 
were not yet built or paid for. After it became clear that federation would end, first Nyasaland and then Northern Rhodesia declared their intentions to withdraw support. Clearly, the medical school was seen as a Southern Rhodesian institution that the Northern territories were giving considerable financial backing to without any real tangible benefit in return. This may have been due to the small representation of students from either Nyasaland or Northern Rhodesia in the first entering cohort. In the event, the school was saved from premature closing only by the injection of a considerable sum of cash from the British government. ${ }^{37}$

The years between 1965 and 1970 were tumultuous for the school. It maintained its commitment to admitting students based on academic merit regardless of race, religion, or gender. UDI ushered in a period of fiscal constraint, shortage of teaching staff, and a growing isolation. By 1970, representatives from the school were excluded from conferences of the Association of Medical Schools in Africa. Further, the declaration of the Rhodesia republic led to the withdrawal of the school's major partner, the University of Birmingham. In addition, the school's graduates were no longer able to register with the General Medical Council in Britain removing reciprocity, one of the most sought after benefits for any medical school in the ex-colonies of Britain. ${ }^{38}$

Evidence of further isolation in the wake of UDI can be seen in the fracturing of the colony's relationship with the World Health Organization (WHO). An associate member, since 1950, Southern Rhodesia had close ties with the organization particularly

37 The amount included $£ 750,000$ for recurrent costs up to 1967 and $£ 800,000$ for capital expenditure. Lindsay Davidson. "Birmingham's Baby: The Beginnings of Medical Education in Rhodesia," British Journal of Medical Education 5, 1 (1971), 64. 38 Ibid.,66-7. 
with regard to research into bilharziasis and malaria. ${ }^{39}$ During the federal era, Southern Rhodesia had been a site for one of the pilot projects on malaria eradication in the mid 1950s. After UDI communication between the two ceased and pre-eradication malaria programs previously agreed on, were scrapped. ${ }^{40}$

\section{Conclusion}

The Federal Health Service illustrates much of the contradictions of federation. It professed to embrace the progressive rhetoric of "partnership" but at the same time its policies can be seen as a determination to maintain the colonial order. To a large extent, professional medical work remained the province of whites. State registered nurse training was extended to Africans but the refusal to open schools in either of the northern territories suggests that this was at best a partial admission that Africans should be part of the professional medical community.

At least in theory, the Central African Federation was a "textbook biopolitical regime. ${ }^{41}$ The Ministry of Health harnessed the language of development to promise better healthcare and opportunities for African people. In practice, the moral basis underpinning healthcare provision was incompatible with a settler desire to maintain the colonial order. Faced with a crisis in staffing, the Federal Health Service responded in ways reminiscent of the earlier colonial period. Officials at the federal health department

\footnotetext{
${ }^{39}$ Blair, future Federal Secretary of Health, had been a consultant to the WHO with regard to bilharziasis.

40 Southern Rhodesia, Report on Public Health, 1966 (BOA), 48.

${ }^{41}$ P. Wenzler Geissler, Para-States and Medical Science: Making African Global Health (Duke University Press, 2015), 2.
} 
maintained a worldview very much in keeping with the colonial past. As such, this thesis illustrates that the development ethos that emerged in the post war period could be subverted to meet settlers' aims and desires.

From an African perspective, the federal era represented a time when the government had promised to promote the health of African societies and advance the interests of Africans by providing careers in the medical professions. When clinics were closed, promises to build hospitals were reneged on, or opportunities for Africans to work in healthcare did not materialize, Africans judged and interpreted these actions as evidence of the failure of federation to live up to its promises and its premise of racial partnership.

When Roy Welensky visited Birmingham University in 1960 to acknowledge the close institutional ties between the British university and the proposed medical school in the Federation, he pointed to the Federal Health Service as evidence of the importance of standards and qualifications to the federal nation-building enterprise. ${ }^{42}$ The speech can be seen as public relations exercise designed to illustrate the biopolitical benevolence of the Federation to an international audience but Welensky's words also underscore a controlling ethos within white settler elite thinking in Southern Rhodesia. Southern Rhodesians based their right to sovereignty on their ability to govern. As far back as 1923, the struggle for settler government autonomy combined the post World War One Wilsonian language of self-determination and Cecil Rhodes' language of “equal rights

42 The Federal Prime Minister Sir Roy Welensky at Birmingham University," CAJM, 7 $(1961,470)$, see this thesis chap. 3, 98). 
for all civilized men" to argue for responsible government. ${ }^{43}$ In the federal era, the language of ability gained currency due to the post Second World War international language of universalism. It was no longer acceptable to frame policies and practices in overt racial terms. In accordance with the new language, African nurses were placed in a lower branch of the Federal Civil Service not because they were black, but because the white elite believed that African nurses had to demonstrate their ability to take on the same responsibilities as the European state registered nurse. In addition, the federal government's refusal to open state registered training to medical aides was justified by a perceived need to ensure that black nursing students would have the academic capacity to pass their examinations. By placing a premium on the requirement to maintain standards, the white settler elite was able to manipulate the language of development and African advancement to fit their desire to maintain a settler colonial order.

Paying attention to settler concerns about standards and qualifications in advanced medical training is important because it illustrates the extent to which settler policies towards the African population in Central Africa were fluid and situational. In an era when universal human rights and citizenship were becoming increasingly significant, the federal language of partnership allowed the federal government to frame its activities as befitting a modern developing nation in the new post war international order. Partnership meant that to be seen to be training African doctors and state registered nurses, for example, was an important part of the image of the Federation to internal and international audiences. However, these settler concerns are also important because they illustrate the ways in which the white elite could marshal the international language of the

${ }^{43}$ Qtd in West, The Rise of an African Middle Class, 5. 
day and accommodate it to their preferred practices and ideas. Welensky's emphasis on the superiority of British medical training shows that the Federal Health Service valued British trained doctors, clearly evident in the recruitment campaign and film designed to entice British doctors to the Federation. As African members of the Federal Assembly pointed out, African doctors and nurses from South Africa faced greater obstacles in finding employment in the federal service despite the desperate shortage of staff. At the same time, training African doctors and nurses made possible a greater degree of segregation in healthcare in the Federation. This appeared to be most important in Southern Rhodesia, where the majority of the European population resided. Here, African medical professionals would care for African patients, not Europeans, and would not be placed in positions of authority where they could challenge and subvert the colonial hierarchy. Hence, the first African state registered nurses to be promoted to the rank of nursing sister worked in the hospitals of Northern Rhodesia or Nyasaland rather than those in Southern Rhodesia.

These insights bring into sharp relief the intentions of the settler state. They are evidence of the Federation's white settler ruling elite's refusal to decolonize even as they accommodated the post war language of universal rights. Most of all, examining the rhetoric and realities of healthcare and access to healthcare professions in the Central African Federation helps us to see more clearly, the ways in which the language of inequality can be made normative in a settler state and how it can persist in the post colonial settler states today. It is the very failure of the Federation to establish a multiracial nation that highlights its unequal practices and policies. 


\section{Bibliography}

\section{Primary Sources}

\section{Archival Sources}

The National Archives London (TNA)

The National Library of Scotland (NLS)

Acc.13582 The Papers of William Oliver Petrie

Bodleian Library, Oxford University

The Welensky Papers

Historical Papers Research Archive, University of the Witswatersrand, South Africa South African Institute Of Race Relations (SAIRR), 1892-1974.

http://www.historicalpapers.wits.ac.za

Godfrey Huggins. National Health Service, Prime Minister's Survey of Conditions in S. Rhodesia. Address to Public Meeting at Bulawayo, Feb 1, 1944. AD1715, Hospitals Beyond South Arica, 9.12.1.4 SAIRR.

Rhodesia and Nyasaland Newsletter. AD1715, Various memos and correspondence on African Welfare Societies in Southern Rhodesia, constitutional affairs and race relations 1953-1964, 27.3.22, SAIRR.

\section{Newspapers, Journals, and Periodicals}

African Eagle

African Weekly

British Medical Journal (BMJ)

Bulawayo Chronicle

Central African Journal of Medicine (CAJM)

FACT

Lancet

Northern News

\section{Government Publications}

Advisory Commission on the Review of the Constitution of the Federation of Rhodesia and Nyasaland, Survey of Developments Since 1953: Cmmd. 1149. London: Her Majesty's Stationary Office, 1960. 
Advisory Commission on the Review of the Constitution of the Federation of Rhodesia and Nyasaland, Report: Cmmd. 1148, Northern Rhodesia. London: HM Stationary Office, 1960.

Advisory Commission on the Review of the Constitution of the Federation of Rhodesia and Nyasaland Report-Appendix VIII, Evidence, Volume I - V: Cmmd. 1151, Northern Rhodesia. London: HM Stationary Office, 1960.

Annual Departmental Reports. Southern Rhodesia, 1895-1980. British Online Archives (BOA).

Annual Departmental Reports. Nyasaland, 1907-1967. British Online Archives (BOA).

Federation of Rhodesia and Nyasaland, Annual Reports on Public Health, 1953-1963 British Online Archives (BOA).

Federation of Rhodesia And Nyasaland, Federal Assembly. Debates of the Federal Assembly. Salisbury: The Government Printer, 1955-1963.

Report of The Commission of Inquiry into the Health and Medical Services of the Federation 1959, Salisbury: The Government Printer, 1960. (Morton Commission)

\section{Memoirs and Autobiographies}

Cowen, Wiiliam. W. A Central African Odyssey. London: The Radcliffe Press, 1995.

Goodhall, John. Goodbye to Empire: A Doctor Remembers. Haddington, Scotland: The Prentland Press, 1987.

Herbert, Eugenia W. Twilight on the Zambezi: Late Colonialism in Central Africa. New York: Palgrave, 2002.

Lessing, Doris. Going Home. London: Michael Joseph Ltd., 1957.

Mkandawire. Austin C, Living My Destiny, A Medical and Historical Narrative. Glasgow, Dudu Nsomba Publications, 1988.

Powdermaker, Hortense. Stranger and friend: the way of an anthropologist. New York: Norton, 1966.

Todd, Judith Garfield. Through the Darkness: A Life in Zimbabwe. Cape Town, SA: Zebra Press, 2007. 


\section{Other Published Primary Sources}

Chesterman, Clement C. "The Training and Employment of African Natives as Medical Assistants.” Proceedings of the Royal Society of Medicine, 25 (1932): 1067-1076.

“Antileprosy Activities in Nyasaland." International Journal of Leprosy, 29, 3 (1961): 367-368.

O’Brien, Henry R. "The Dawn of Medical Education in Tropical Africa." Journal of Medical Education, 33 (1955): 153-164.

\section{Secondary Sources}

Anderson, Warwick. "How's the Empire: An Essay Review." Journal of the History of Medicine and Allied Sciences, 58 (2003): 459-465.

Arnold, David, ed. Imperial Medicine and Indigenous Societies. Manchester: Manchester University Press, 1988.

Baker, Colin, ed. An Expatriate Experience of Life and Work in Nyasaland. 5 vols. Cardiff, Mbemba Books, 2012-2016.

Baker, Colin. "The Government Medical Service in Malawi: An Administrative History, 1891-197.” Medical History 20 (1976): 296-311.

Baker, Colin. Revolt of the Ministers: The Malawi Cabinet Crisis 1964-1965. London: I.B.Taurus, 2001.

Barnes, Terri. “We Women Worked so Hard”: Gender, Urbanization, and Social Reproduction in Colonial Harare, Zimbabwe, 1930-1956. Portsmouth, NH: Heinemann, 1999.

Bonneuil, Christophe. "Development as Experiment: Science and State Building in Late Colonial and Postcolonial Africa, 1930-1970." Osiris, 15 (2000): 258-81.

Brownell, Josiah. "The Hole in Rhodesia's Bucket: White Emigration and the End of Settler Rule.” Journal of Southern African Studies 34 (2008): 591-610.

Burdette, Marcia M. Zambia: Between Two Worlds. Boulder, Co.: Westview Press, 1988.

Callahan, Bryan. "“Veni, VD, Vici'?: Reassessing the Ila Syphilis Epidemic," Journal of Southern African Studies 23 (1997): 421-40. 
Callahan Bryan T. and Virginia Bond, "The Social, Cultural, and Epidemiological History of Sexually Transmitted Disease in Zambia." In Setel, Histories of Sexually transmitted diseases and HIV Aids in Sub-Saharan Africa, 168-195.

Cohen, Andrew. "Voice and Vision" - The Federation of Rhodesia and Nyasaland's Public Relations Campaign in Britain: 1960-1963." Historia 54 (2009): 113-132.

Cooper Barbara. "Women and Gender." In The Oxford Handbook of Modern African History, edited by John Parker and Richard Reid, 338-358. Oxford: Oxford University Press, 2013.

Cooper, Frederick. Africa since 1940: The Past of the Present. Cambridge: Cambridge University Press, 2002.

Cooper, Frederick. Decolonization and African Society: The Labor Question in French and British Africa. Cambridge: Cambridge University Press, 1996.

Cooper, Frederick. "Modernizing Bureaucrats, Backward Africans, and the Development Concept." In International Development and the Social Sciences, edited by F. Cooper and R.M. Packard, 63-92. Berkeley: University of California Press, 1997.

Crozier, Anna. Practising Colonial Medicine: The Colonial Medical Service in British East Africa. London: I.B. Tauris \& Co, 2007.

Creighton, T. R. M. Southern Rhodesia and the Central African Federation: The Anatomy of Partnership. New York: Praeger, 1961.

Currie, Marion. Livingstone's Hospital, The Story of Chitambo. Bloomington, IN: AuthorHouse, 2011.

Curtin, Philip D. Death by Migration: Europe's Encounter with the Tropical World in the Nineteenth Century. Cambridge: Cambridge University Press, 1989.

Davidson, Lindsay. "Birmingham's Baby: The Beginnings of Medical Education in Rhodesia." British Journal of Medical Education 5 (1971): 61-74.

Dawson, Marc and Helen Tilley. "Ecologies of Complexity: Tropical Environments, African Trypanosomiasis, and the Science of Disease Control in British Colonial Africa, 1900-1940.” Osiris 19 (2004): 21-38.

Engels, Dagmar, and Shula Marks. Contesting Colonial Hegemony: State and Society in Africa and India. London: British Academic Press, 1994. 
Epprecht, Marc. "Black skin, 'cowboy' masculinity: a genealogy of homophobia in the African nationalist movement in Zimbabwe to 1983." Culture, Health \& Sexuality 7 (May, 2005): 253-266.

Fairhead, James and Melissa Leach. Misreading the African Landscape: Society and Ecology in a Forest-savanna Mosaic. Cambridge: Cambridge University Press, 1996.

Farmer, Paul, Arthur Kleinman, Jim Yong Kim, and Mathew Basilico, Reimagining Global Health: An Introduction. Berkeley: University of California Press, 2013.

Feierman, Steven. "Explanation and Uncertainty in the Medical World of Ghaambo." Bulletin of the History of Medicine 74 (2000): 317-44.

Feierman, Steven. "Struggles for Control: The Social Roots of Health and Healing in Modern Africa." African Studies Review 28 (1985): 73-147.

Fraenkel, Peter. No Fixed Abode A Jewish Odyssey to Freedom in Africa. London:

I.B.Tauris, 2005.

Geissler Wenzel, Paul. Para-States and Medical Science: Making African Global Health. Durham: Duke University Press, 2015.

Gelfand Michael, A Proud Record. Salisbury (Harare): Government Printer for the Federal Bureau of Information, 1960.

Gelfand Michael. A Service to the Sick. Harare: Mambo Press, 1976.

Gelfand Michael. Godly Medicine in Zimbabwe. Harare: Mambo Press, 1988.

Gelfand, Michael. The Sick African: A Clinical Study. Cape Town: Juta, 1957.

George, Abosede A. Making Modern Girls: A History of Girlhood, Labor, and Social Development in Colonial Lagos. Athens, OH: Ohio University Press, 2014.

Good, Charles. The Steamer Parish: The Rise and Fall of Missionary Medicine on an African Frontier. London: University of Chicago Press, 2004.

Gray, John Richard. The Two Nations Aspects of the Development of Race Relations in the Rhodesias and Nyasaland. London: Oxford University Press, 1960.

Greenwood, Anna ed. Beyond the State: The Colonial Medical Service in British Africa. Manchester: Manchester University Press, 2016. 
Gros, Jean-Germain. Healthcare Policy in Africa: Institutions and Politics from Colonialism to the Present. London: Rowman \& Littlefield, 2016.

Hodgson, Dorothy L. "Pastoralism, Patriarchy and History: Changing Gender Relations among Maasai in Tanganyika, 1890-1940." Journal of African History 40 (1999): 41-65.

Hokkanen, Markku. "The government medical service and British missions in colonial Malawi, c. 1891-1940: crucial collaboration, hidden conflicts." In Greenwood, Beyond the State, 39-63.

Hokkanen, Markku. "Missions, Nurses and Knowledge Transfer: The Case of Early Colonial Malawi." In Transnational and Historical Perspectives on Global Health, Welfare and Humanitarianism, edited by E. Fleischmann, S. Grypma, M. Marten, \& I. Okkenhaug, 110-136. Kristiansand: Portal Academic, 2013.

Hunt, Nancy Rose. A Colonial Lexicon of Birth Ritual, Medicalization, and Mobility in the Congo. Durham: Duke University Press 1999.

Hunt, Nancy Rose. A Nervous State: Violence, Remedies, and Reverie in Colonial Congo. Durham: Duke University Press, 2016.

Hunt, Nancy Rose. "Letter-writing, Nursing men and Bicycles in the Belgian Congo: Notes Towards the Social Identity of a Colonial Category." In Paths Toward the Past, African Historical Essays in Honor of Jan Vansina, edited by Robert W. Harms et al., 187-189. Atlanta, GA: African Studies Association Press, 1994.

Hyam, Ronald. "The Geopolitical Origins of the Central African Federation: Britain, Rhodesia and South Africa, 1948-1953." The Historical Journal 30, no. 1 (1987): 145-72.

Iliffe, John. East African Doctors: A History of the Modern Profession. Kampala, Uganda: Fountain Publishing, 2002.

Jennings, Michael "Cooperation and competition: missions, the colonial state and constructing a health system in colonial Tanganyika," In Greenwood, Beyond the State, 153-173.

Johnson, Jennifer. The Battle for Algeria: Sovereignty, Health Care, and Humanitarianism. Philadelphia: University of Pennsylvania Press, 2016.

Kalinga, Owen. "The 1959 Nyasaland State of Emergency in Old Karonga District." Journal of Southern African Studies 36 (2010), 743-763. 
Kalusa, Walima T. "Aspects of Health in the Mining Industry in Colonial Zambia: A Case Study of the Roan Antelope Mine, 1920-1964." Master's thesis, University of Zambia, 1993.

Kalusa, Walima T. "Language, Medical Auxiliaries, and the Reinterpretation of Missionary Medicine in Colonial Mwinilunga, Zambia, 1922-51." Journal of Eastern African Studies 1 (2007): 57-78.

Kalusa, Walima T. "Disease And The Remaking Of Missionary Medicine In Colonial Northwestern Zambia: A Case Study Of Mwinilunga District, 1902-1964.” PhD diss., John Hopkins University, 2003. ProQuest Dissertations and Theses.

Keller, Richard C. "Geographies of Power, Legacies of Mistrust: Colonial Medicine in the Global Present." Historical Geography 34 (2006): 26-48.

Kumwenda, Godfrey Kabaya. "The Role and Conditions of Service of African Medical Auxiliaries in Catholic Mission Health Institutions In Zambia: A Case Study of Chilonga Mission Hospital in Mpika District, 1905-1973," Masters Thesis, 2015, University of Zambia.

Kumwenda, Linda Beer. "The Training of Female Medical Auxiliaries in Missionary Hospitals in Northern Rhodesia, 1928-1952." Social Sciences and Missions 16 (July 2005): 103-132.

Kumwenda, Linda Beer. "The Medical Personnel of the Universities' Mission to Central Africa." In Healing Bodies, Saving Souls: Medical Missions in Asia and Africa, edited by David Hardiman, 193-226. Amsterdam: Rodopi BV, 2006.

Küster, Sybille. Neither Cultural Imperialism nor Precious Gift of Civilization: African Education in Colonial Zimbabwe 1890-1962. Studien Zur Afrikanischen Geschichte; Bd. 8. Münster: Lit, 1994.

Leys, Colin. European Politics in Southern Rhodesia. Westport, Conn: Greenwood Press, 1959.

Lwanda, John. "Doctoring the Brain Drain: Medical Case of Malawi." African Issues 30 (2002): 47-51.

Lindsay, Lisa A. "Domesticity and Difference: Male Breadwinners, Working Women, and Colonial Citizenship in the 1945 Nigerian General Strike." The American Historical Review 104 (1999): 783-812.

Livingston, Julie. Debility and the Moral Imagination in Botswana. Bloomington: Indiana University Press, 2005. 
Lodge, Tom, Denis Kadima, and David Pottie. "Malawi." In Compendium of elections in Southern Africa, edited by Tom Lodge et al. Johannesburg: Electoral Institute of Southern Africa, 2002.

Lowry, Donal, "Rhodesia 1890-1980, 'The Lost Dominion."' In Settlers and Expatriates: Britons over the Seas, edited by Robert A. Bickers, 112-149. Oxford: Oxford University Press, 2010.

Lyons, Maryinez. "From 'Death Camps' to Cordon Sanitaire: The Development of Sleeping Sickness Policy in the Uele District of the Belgian Congo, 1903-1914." The Journal of African History 26 (1985): 69-91.

MacLeod Roy and Milton Lewis, eds., Disease, Medicine and Empire: Perspectives on Western Medicine and the Experience of European Expansion. London \& New York: Routledge, 1988.

Marks, Shula. Divided Sisterhood: Race, Class and Gender in the South African Nursing Profession (Basingstoke, UK: The Macmillan Press, 1994.

Marks, Shula and Neil Andersson, "Industrialization, Rural Health and the National Health Service Commission in South Africa." In The Social Basis of Health and Healing in Africa, edited by Steven Feierman and John Janzen, 131-174. Berkeley: University of California Press, 1992.

Marks, Shula. "The Legacy of the History of Nursing for Post-Apartheid South Africa." In Nursing History and the Politics of Welfare, edited by Ann Marie Rafferty, Jane Robinson and Ruth Elkin, 28-44. London: Routledge, 1997.

Marsh, B.D. “'Multiracial Partnership' and African Health Care in the Central African Federation." In Health, Knowledge, and Belief Systems in Africa, edited by Toyin Falola and Mathew Heaton, 261-276. Durham, N.C. : Carolina Academic Press, 2008 .

Masakure, Clement. "On the Frontline of Caring: A History of African Nurses in Colonial and Postcolonial Zimbabwe: 1940s-1996.” PhD diss., University Of Minnesota, 2012. ProQuest Dissertations and Theses.

Masakure, Clement. "One of the most serious problems confronting us at present:" Nurses and government hospitals in Southern Rhodesia, 1930s to 1950." Historia, 60 (2015): 109-131.

McCulloch, Jock. "The Management of Venereal Disease in a Settler Society: Colonial Zimbabwe, 1900-30." In Setel, Histories of Sexually transmitted diseases and HIV Aids in Sub-Saharan Africa, 196-216. 
McCracken. John. A History of Malawi 1859-1966. Rochester, NY: James Currey, 2012.

McGregor, JoAnn and Terence Ranger, "Displacement and Disease: Epidemics and Ideas about Malaria in Matabeleland, Zimbabwe, 1945-1996.” Past \& Present, 167 (2000): 203-237.

Messac, Luke "Moral hazards and Moral Economies: The Combustible Politics of Healthcare User Fees in Malawian History." South African Historical Journal, 66 (2014): 376-380.

Mkandawire, Thandika. "Thinking about Developmental States in Africa." Cambridge Journal of Economics 25, 3 (2001): 289-313.

Mlambo, Alois S. A History of Zimbabwe Cambridge: Cambridge University Press, 2014.

Monnais-Rousselot, Laurence, and Wright, David. Doctors beyond Borders: The Transnational Migration of Physicians in the Twentieth Century. Toronto: University of Toronto Press, 2016.

Morris, Brian. An Environmental History of Southern Malawi: Land and People of the Shire Highlands. Cham: Springer International Publishing, 2016.

Murphy, Philip. "Acceptable Levels? The Use and Threat of Violence in Central Africa, 1953-1964." In The Ends of European Colonial Empires: Cases and Comparisons, edited by Miguel Bandeira Jerónimo and António Costa Pinto, 178-196. London: Palgrave Macmillan, 2015.

Murphy, Philip. "A Police State? The Nyasaland Emergency and Colonial Intelligence." Journal of Southern African Studies, 36, 4 (2010): 765-780.

Murphy, Philip. British Documents on the End of Empire: Central Africa, Part I: Closer Association 1945- 1958, edited by Phillip Murphy. London: The Stationary Office, 2005.

Murphy, Philip. “'Government By Blackmail': The Origins of the Central African Federation Reconsidered. In The British Empire in the 1950s: Retreat or Revival, edited by Martin Lynn, 53-76. London: Palgrave Macmillan, 2006.

Ncube, Glen. "“The Problem of the Health of the Native': Colonial Rule and the Rural African Healthcare Question in Zimbabwe, 1890s-1930," South African Historical Journal, 64, 4 (2012): 807-826.

Ncube, Glen. "The Making Of Rural Healthcare In Colonial Zimbabwe: A History Of The Ndanga Medical Unit, Fort Victoria, 1930-1960s." Ph.D diss, University of Cape Town, 2012. ProQuest Dissertations and Theses. 
Omeje, Kenneth C., and Tricia M. Redeker Hepner. Conflict and Peacebuilding in the African Great Lakes Region. Bloomington, Ind: Indiana University Press. 2013.

Packard, Randall. A History of Global Health: Interventions into The Lives of Other Peoples. Baltimore: John Hopkins University Press, 2016.

Packard, Randall M. "Malaria Dreams: Postwar Visions of Health and Development in the Third World." Medical Anthropology, 17 (1997): 279-296.

Packard, Randall M. "Tuberculosis and the Development of Industrial Health Policies on the Witwatersrand, 1902-1932." Journal of Southern African Studies 13, Special Issue on The Political Economy of Health in Southern Africa (1987): 187-209.

Packard, Randall. "Visions of Postwar Health and Development and their Impact on Public Health Interventions in the Developing World." In International Development and the Social Sciences, edited by F. Cooper and R.M. Packard, 93-118. Berkeley: University of California Press, 1997.

Packard, Randall M. White Plague, Black Labor: Tuberculosis and the Political Economy of Health and Disease in South Africa. Berkeley: University of California Press, 1989.

Phiri, B. J. A Political History of Zambia : From Colonial Rule to the Third Republic, 1890-2001. Trenton, NJ: Africa World Press, 2006.

Porter, Roy. The Greatest Benefit to Mankind: A Medical History of Humanity. New York: W. W. Norton \& Co., 1999.

Powdermaker, Hortense. Copper Town: Changing Africa; the Human Situation on the Rhodesian Copperbelt. New York: Harper \& Row, 1962.

Power, Joey. Political Culture and Nationalism in Malawi: Building Kwacha. New York: University of Rochester, 2010.

Pritchett, James A. Friends for Life, Friends for Death: Cohorts and Consciousness Among the Lunda-Ndembu. Charlottesville: University of Virginia Press, 2007.

Prince, Ruth. "Situating Health and the Public in Africa: Historical and Anthropological Perspectives." In Making and Unmaking Public Health in Africa: Ethnographic and Historical Perspectives, edited by Ruth Prince and Rebecca Marsland, 18-24.

Athens, OH: Ohio University Press, 2014.

Pringle, Yolana. "Crossing the Divide: Medical Missionaries and Government Service in Uganda, 1897-1940.” In Greenwood, Beyond the State, 19-38. 
Raftopoulos, Brian and Alois Mlambo, eds. Becoming Zimbabwe A History from the Precolonial Period to 2008. Oxford: Weaver Press, 2009.

Reinhardt, Bob H. The End of a Global Pox: America and the Eradication of Smallpox in the Cold War Era. Chapel Hill, NC: The University of North Carolina Press, 2015.

Reid, Richard J. A History of Modern Africa: 1800 to the Present. Hoboken: John Wiley \& Sons, 2011.

Rennick Agnes. "Church And Medicine: The Role Of Medical Missionaries In Malawi 1875-1914.” Ph.D diss., University of Stirling, 2003. ProQuest Dissertations and Theses.

Roberts, Andrew. A History of Zambia. London: Heinemann. 1976.

Rotberg, Robert. The Rise of Nationalism in Central Africa. London: Oxford University Press, 1965.

Schmidt Elizabeth. Peasants Traders and Wives: Shona Women in the History of Zimbabwe, 1870-1939. Portsmouth, NH: Heinemann Educational Books, 1992.

Scott, James. Seeing Like a State: How Certain Schemes to Improve the Human Condition have Failed. New Haven: Yale Univ. Press, 1998.

Setel, Philip W., Milton Lewis, and Maryinez Lyons, eds. Histories of Sexually transmitted diseases and HIV Aids in Sub-Saharan Africa. Westport, Conn: Greenwood Press, 1999.

Shutt, Allison Kim. Manners Make a Nation: Racial Etiquette in Southern Rhodesia, 1910-1963. Rochester, NY: University of Rochester Press, 2015.

Smit, Joyce. "The Training of African Nurses in Nyasaland (Malawi) from 1887 to 1927." Curationis 11 (July 1988): 4-7.

Solano, Diana and Marie Anne Rafferty. "Can Lessons Be Learned from History? The Origins of the British Imperial Nurse Labour Market: A Discussion Paper." International Journal of Nursing Studies, 44 (2007): 1055-1063.

Stoler, Anne Laura and Frederick Cooper. "Between Colony and Metropole: Rethinking a Research Agenda." In Tensions of Empire: Colonial Cultures in a Bourgeois World, edited by Anne Laura Stoler and Frederick Cooper, 1-58. Berkeley: University of California Press, 1997.

Stuart, John. British Missionaries and The End of Empire: East, Central, and Southern 
Africa, 1939-64. Grand Rapids, Mich.: W.B. Eerdmans, 2011.

Summers, Carol. Colonial Lessons: Africans' Education in Southern Rhodesia, 19181940. Portsmouth, NH: Heinemann, 2002.

Swanson, Maynard W. "The Sanitation Syndrome: Bubonic Plague and Urban Native Policy in the Cape Colony, 1900-1909." The Journal of African History 18, 3 (1977), 387-410.

Sweet, Helen M., and Hawkins, Sue. Colonial Caring: A History of Colonial and PostColonial Nursing. Manchester, UK: Manchester University Press, 2015.

Tilley, Helen. Africa as a Living Laboratory: Empire, Development, and the Problem of Scientific Knowledge, 1870-1950. Chicago: University of Chicago Press, 2011.

Tischler, Julia. Light and Power for a Multiracial Nation: The Kariba Dam Scheme in the Central African Federation. Houndmills, Basingstoke, UK: Palgrave Macmillan, 2013.

Utzinger, J, Y. Tozan, F. Doumani, and B. H. Singer, "The economic payoffs of integrated malaria control in the Zambian Copperbelt between 1930 and 1950." Tropical Medicine \& International Health 7 (2002): 657-677.

Vaughan, Megan. Curing their Ills: Colonial Power and African Illness. Stanford University Press, 1991.

Veracini, Lorenzo. "Introducing." Settler Colonial Studies 1 (2011): 1-12.

Veracini, Lorenzo. Settler Colonialism: A Theoretical Overview. New York: Palgrave Macmillan, 2010.

Wall, Barbra M. Into Africa: A Transnational History of Catholic Medical Missions and Social Change. New Brunswick, New Jersey: Rutgers University Press, 2015.

Waller, Richard. "Emutai: Crisis and Response in Maasailand, 1883-1902." In The Ecology of Survival: Case Studies from Northeast African History, edited by D. Johnson and D. Anderson, 73-112. Boulder, Co.: Westview Press, 1998.

Watson, Malcolm. African Highway: The Battle for Health in Central Africa. John Murray: London, 1953.

Weitzer, Ronald John. Transforming Settler States: Communal Conflict and Internal Security in Northern Ireland and Zimbabwe. Berkeley: University of California Press, 1990. 
Wendland, Claire L. A Heart for The Work: Journeys through an African Medical School. Chicago: University of Chicago Press, 2010.

West, Michael. The Rise of an African Middle Class. Bloomington, IN: Indiana University Press, 2002.

White, Luise. Comforts of Home: Prostitution in Colonial Nairobi. Chicago: University of Chicago Press, 1990.

White, Luise. Speaking With Vampires: Rumor and History in Colonial Africa. Berkeley: University of California Press, 2000.

White, Luise. Unpopular Sovereignty: Rhodesian Independence and African Decolonization. Chicago: University of Chicago Press, 2015.

Wolfe Patrick. "Settler Colonialism and the elimination of the native." Journal of Genocide Research, 8 (2006): 387-409.

Wood, J.R.T. The Welensky Papers: A History of the Federation and Nyasaland. Durban, SA: Graham Publishing, 1983.

Worboys, Michael. "The Discovery of Colonial Nutrition." In Imperial Medicine and Indigenous Societies, edited by David Arnold, 208-226. Manchester: Manchester University Press, 1988.

Young, Crawford. The African Colonial State in Comparative Perspective. New Haven: Yale University Press, 1994. 